\title{
Bedronoe
}

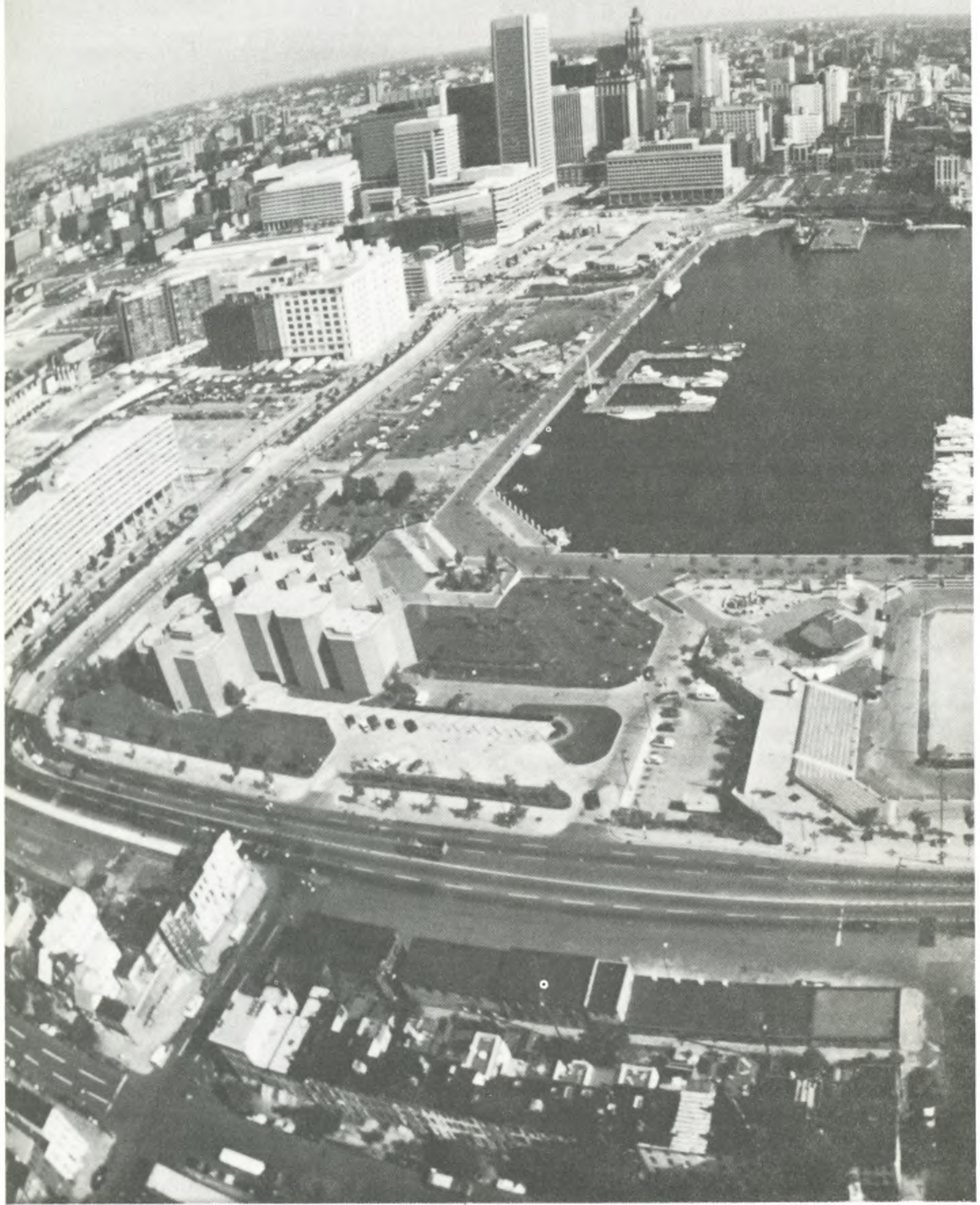




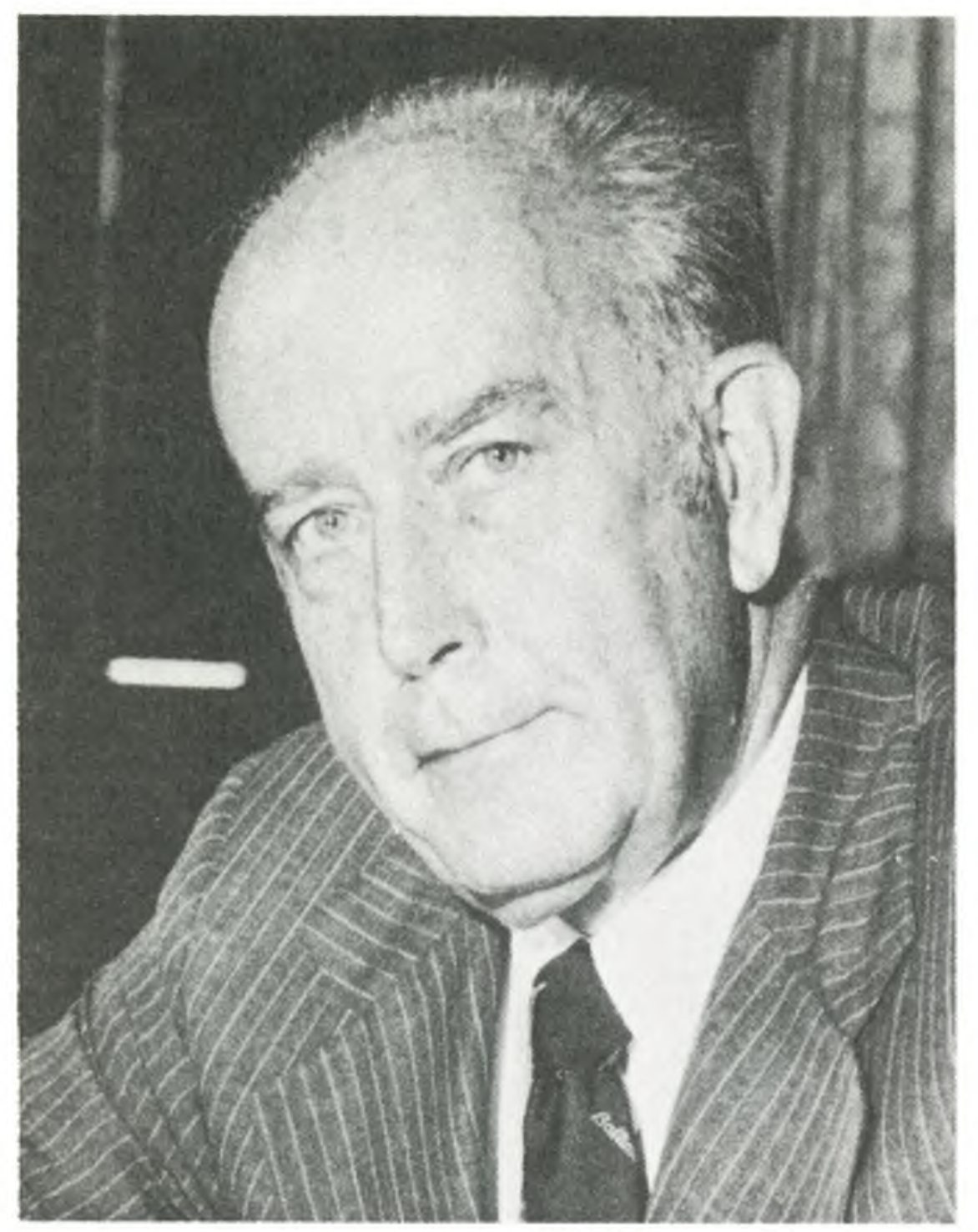

William Schaefer Mayor of Baltimore

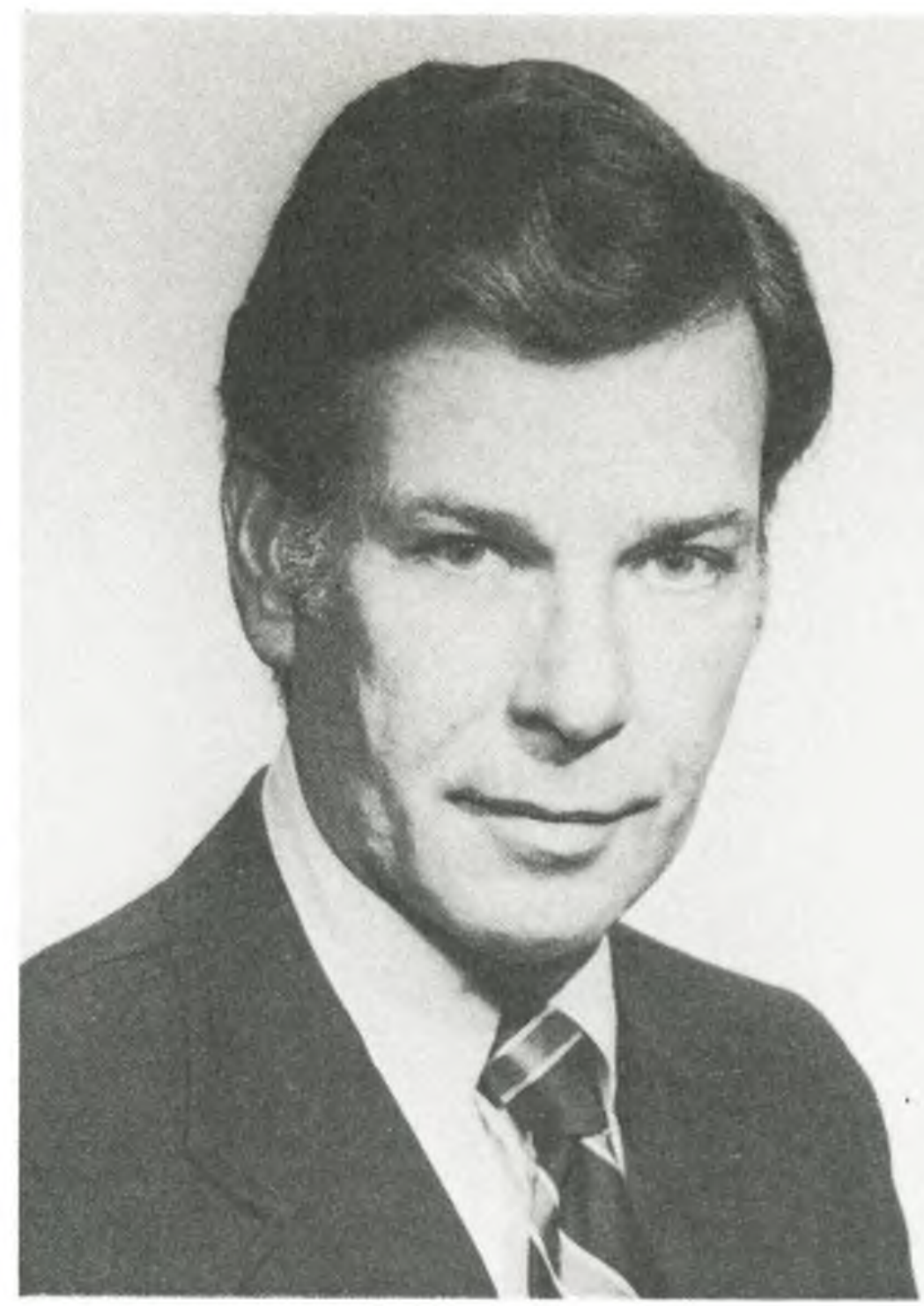

Harry Hughes

Governor of Maryland

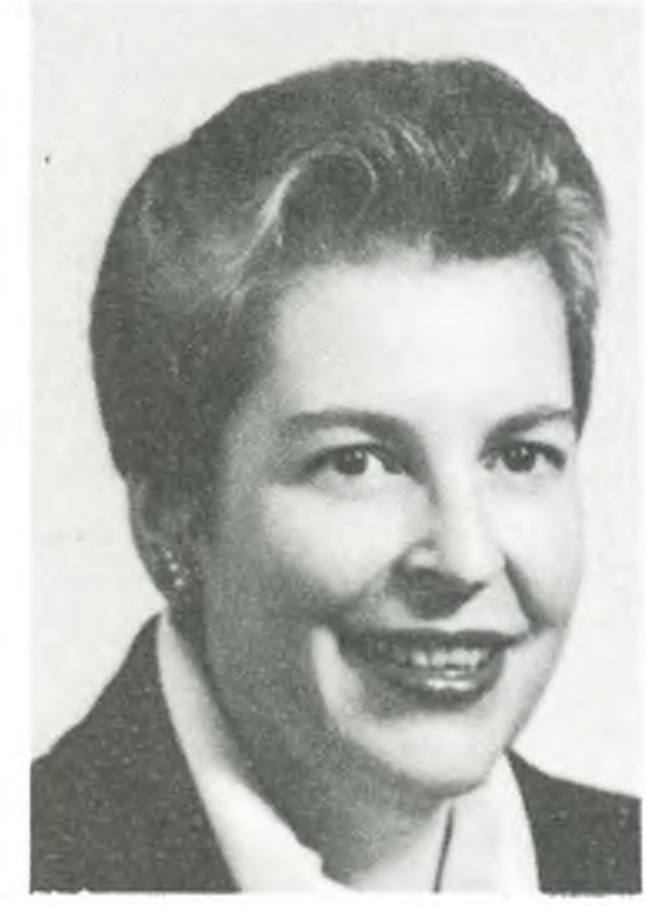

H. Joanne Harrar

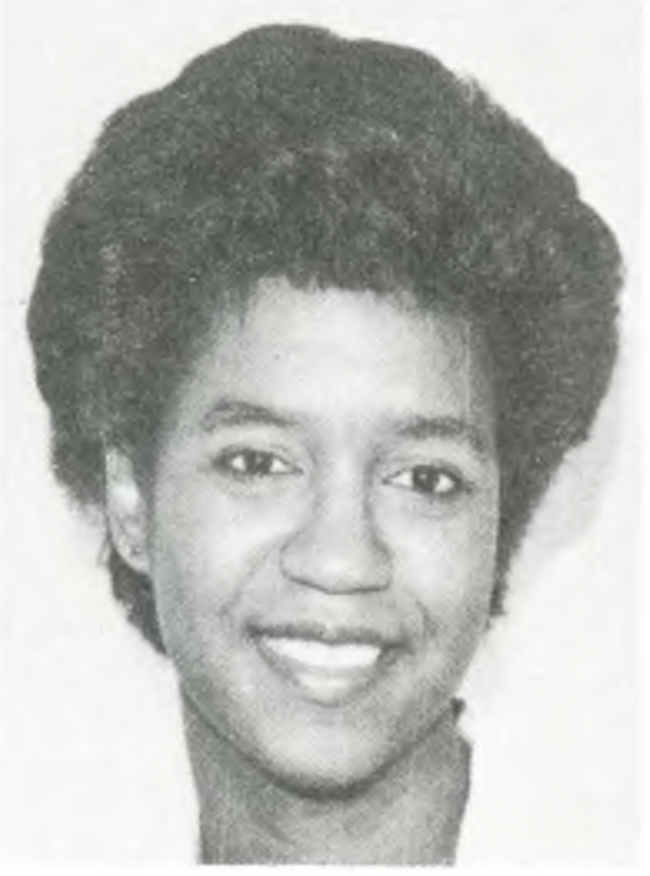

Bonita Perry

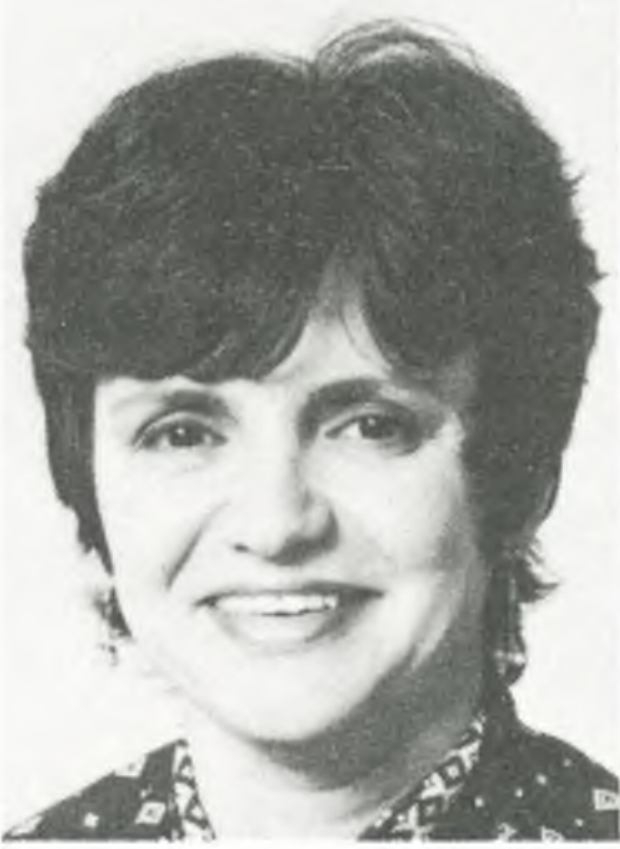

Charmaine S. Boyd

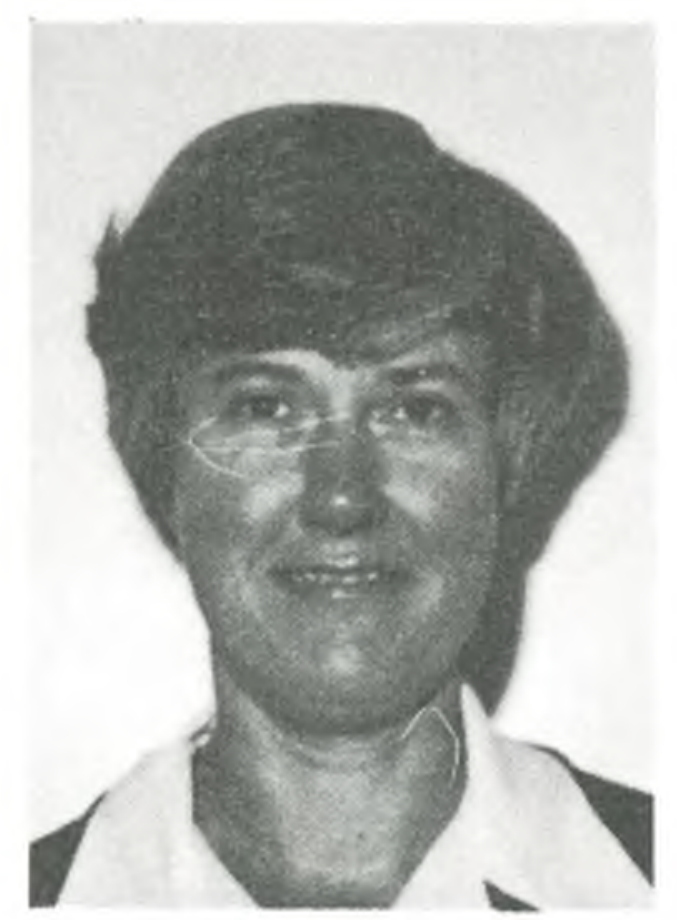

Suzanne P. Hill

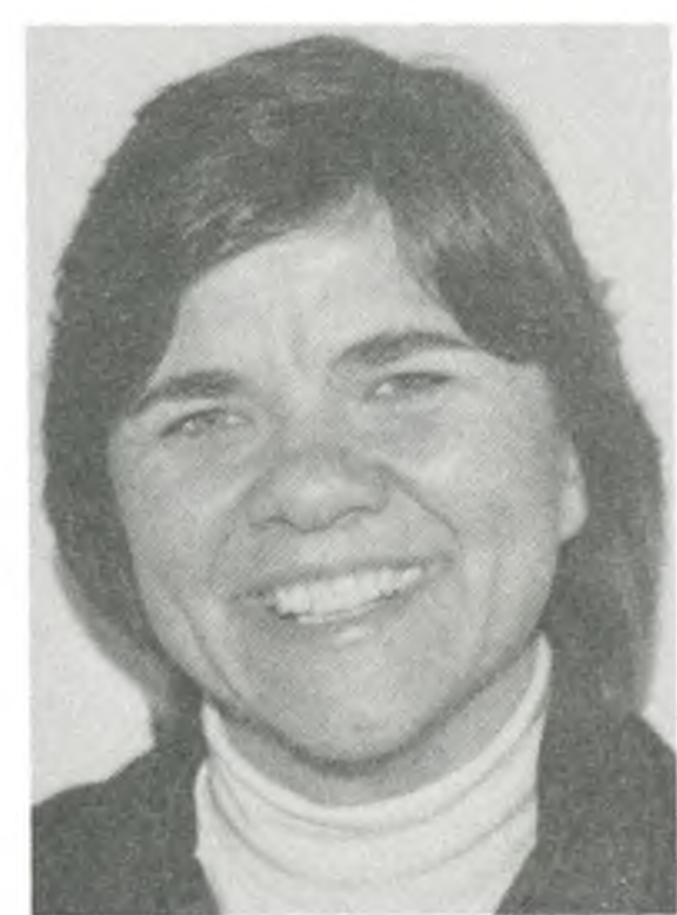

Danuta A. Nitecki 


\section{An invitation to the Baltimore Conference}

We would like to invite you to join us in Baltimore, April 9-12, 1986, for ACRL's Fourth National Conference, "Energies for Transition." Come to the Inner Harbor and share with your colleagues the sights and sounds which characterize Baltimore-a city in transition, a tangible symbol of the Conference theme.

You will be able to participate in discussing idea briefs, and listen as your colleagues present position and research papers on a range of topics which concern the academic librarian. You can refine your knowledge of vendors' wares through the Exhibitors New Product Seminar (a highlight of the Third National Conference which will be repeated) featuring the latest in products and services.

You will be able to hear speakers, prominent in higher education, publishing, computer design and the arts, discuss future trends and how these will affect academic and research libraries.

You will have opportunities to see the historic and newly-renovated Enoch Pratt Free Public Library and the acclaimed National Aquarium as you attend the conference receptions to be held in each. You can visit special and academic libraries in the area, and see Baltimore, be it on a city tour or via the "Early Bird Insomniac's Tour." Be sure to sample the ethnic food for which old Baltimore is famous.

Baseball, boat rides, concerts, cabaret and theater-during your evening on the town you will be enticed to sample any number of diversions and entertainments.

Your Baltimore area colleagues and members of the several conference planning committees look forward to seeing you in April!

Sincerely,

\section{H. Joanne Harrar}

Chair, Conference Executive Committee

Director of Libraries

University of Maryland-College Park

\section{ACRL Fourth National Conference Committee}

Conference Chair: H. Joanne Harrar, Director of Libraries, University of Maryland, College Park, MD 20742.

Program Committee: Bonita Perry (chair), Assistant Director for Reader Services, Milton S. Eisenhower Library, Johns Hopkins University, Baltimore, MD 21218; Martin Smith, Science/Engineering Bibliographer, Milton S. Eisenhower Library, Johns Hopkins University, Baltimore, MD 21218; Sr. Mary Ian Stewart, Library Director, Loyola/Notre Dame Library, 200 Winston Ave., Baltimore, MD 21212.

Special Events: Diana Cunningham (chair), Network Coordinator, Division of Library Development and Services, Maryland State Dep't of Education, $200 \mathrm{~W}$. Baltimore St., Baltimore, MD 21201; Susan Arrington, Head, Government Reference Services, Enoch Pratt Free Library, $400 \mathrm{Ca}-$ thedral St., Baltimore, MD 21201; Dara Cook, Public Services Librarian, Catonsville Community College, 800 S. Rolling Rd., Baltimore, MD 21228; Bonnie Preston, Special Information and Bibliographic Instruction Librarian, Catonsville Com- munity College, 800 S. Rolling Rd., Baltimore, MD 21228; Larry Wilt, Head, Technical Services, Albert O. Kuhn Library and Gallery, University of Maryland Baltimore County, 5401 Wilkens Ave., Baltimore, MD 21228.

Publicity: Charmaine S. Boyd (chair), Coordinator, User Services Library/Media Center, Prince George's Community College, 301 Largo Road, Largo, MD 20772; Marianne C. Rough, Librarian, Library/Media Center, Prince George's Community College, 301 Largo Road, Largo, MD 20772; William G. Wilson, Librarian and Lecturer, University of Maryland Libraries, College Park, MD 20742.

Local Arrangements/Hospitality: Suzanne P. Hill (chair), Director of Library Services, Catonsville Community College, 800 S. Rolling Road, Baltimore, MD 21228; Eleanor O. Hofstetter, Associate Director, Albert S. Cook Library, Towson State University, Baltimore, MD 21204; Ruth E. Kifer, Collection Development Librarian, Learning Resources Center, Catonsville Community College, $800 \mathrm{~S}$. Rolling Road, Baltimore, MD 
21228; Susan Mower, Documents Librarian, Albert S. Cook Library, Towson State University, Baltimore, MD 21204; Simmona Simmons, Assistant to Head of Reference, Albin O. Kuhn Library, University of Maryland, Catonsville, MD 21228; Joyce Tenney, 910 Hammonds Lane, Baltimore, MD 21225.

Contributed Papers: Danuta A. Nitecki (chair), Associate Director for Public Services, McKeldin Library, University of Maryland Libraries, College Park, MD 20742; Arnold Bellefontaine, Executive Officer, Associate Librarian for National Programs, Library of Congress, Washington, DC
20540; Keith Russell, Public Services Division, National Agriculture Library, Beltsville, MD 20705.

Consultants: Gary L. Menges, Coordinator of Special Collections and Preservation, Suzzallo Library, FM-25, University of Washington, Seattle, WA 98195; Vicki Kreimeyer, Associate Director for Information Services, Idaho State Library, 325 W. State, Boise, ID 83702.

Exhibits Manager: Sandy Donnelly, ACRL/ALA, 50 E. Huron St., Chicago, IL 60611. ACRL Staff Liaison: Cathleen Bourdon, ACRL/ALA, 50 E. Huron St., Chicago, IL 60611.

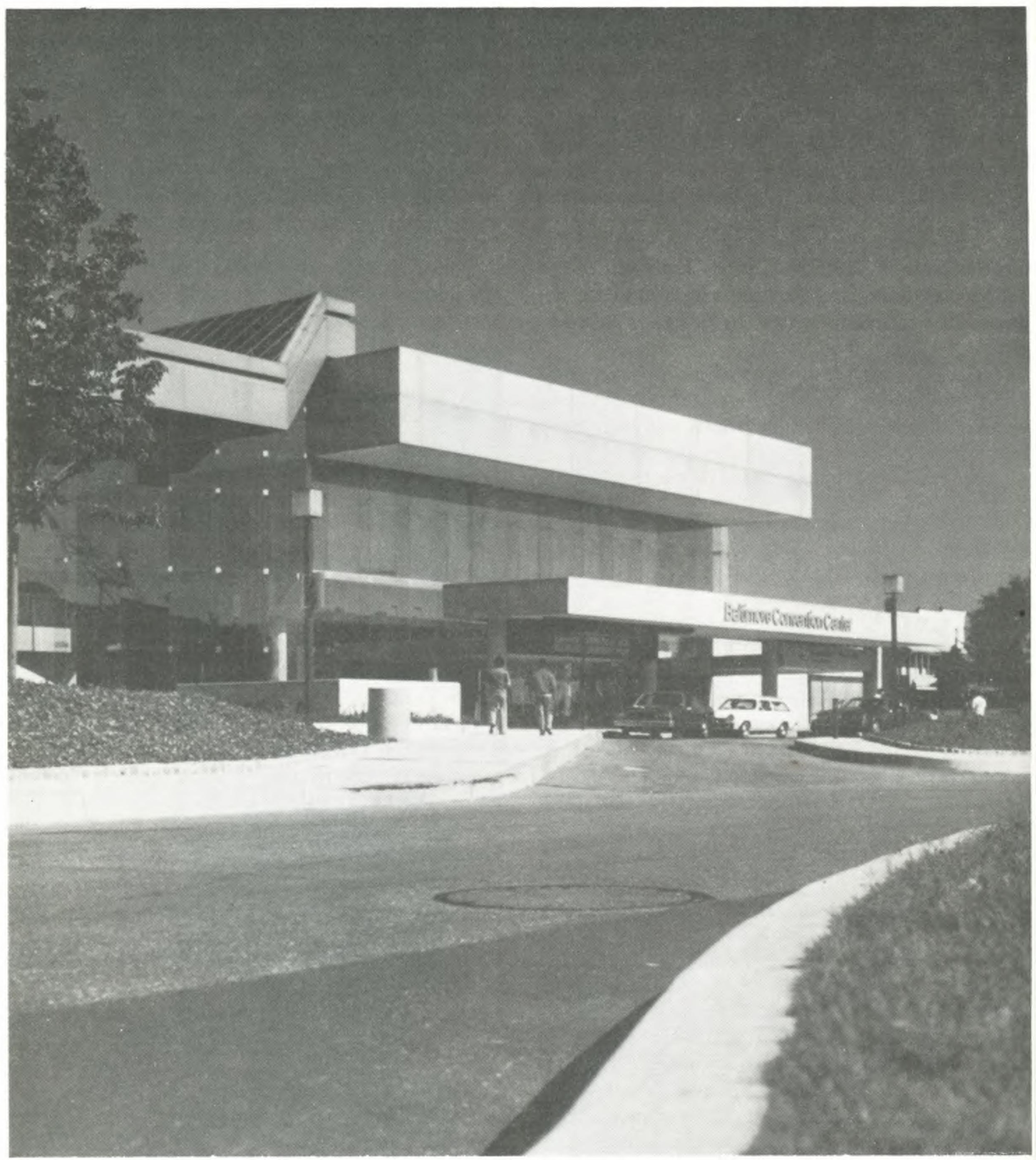

The Baltimore Convention Center, site of ACRL's Fourth National Conference. 


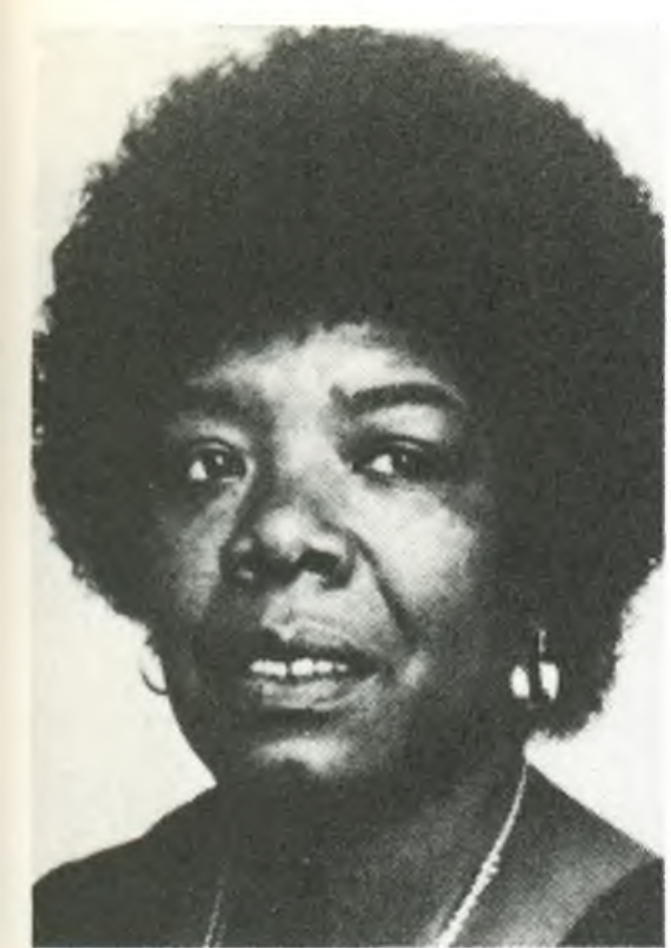

Maya Angelou

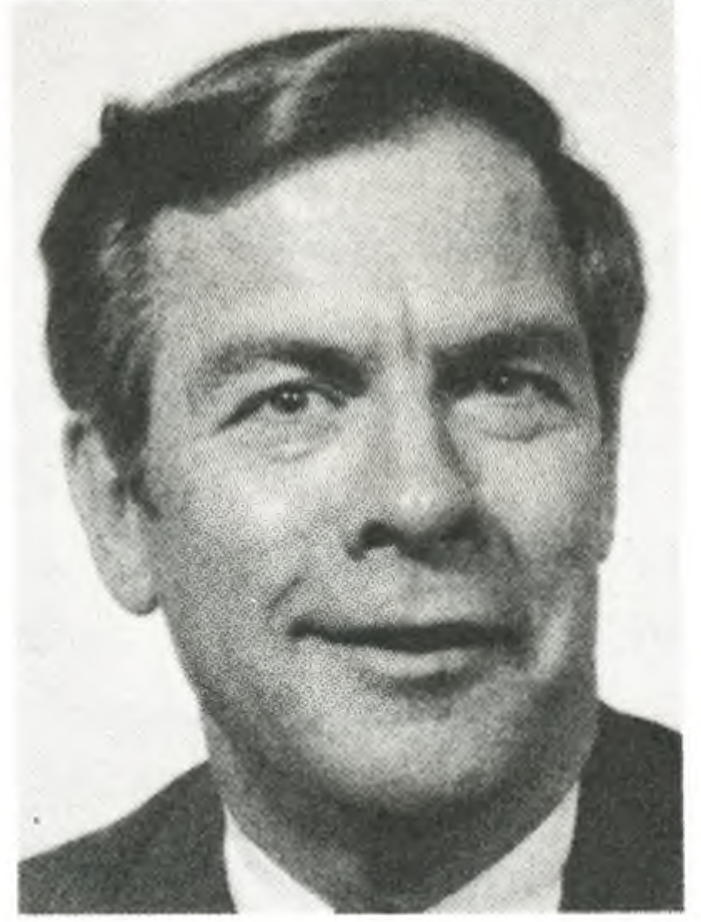

Robert Asleson

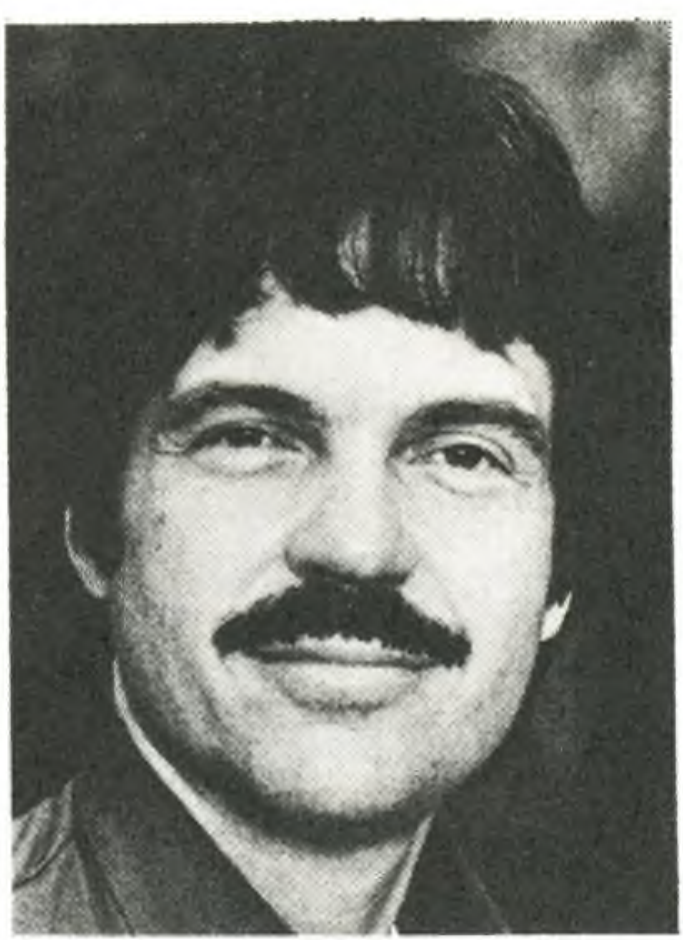

Alan C. Kay

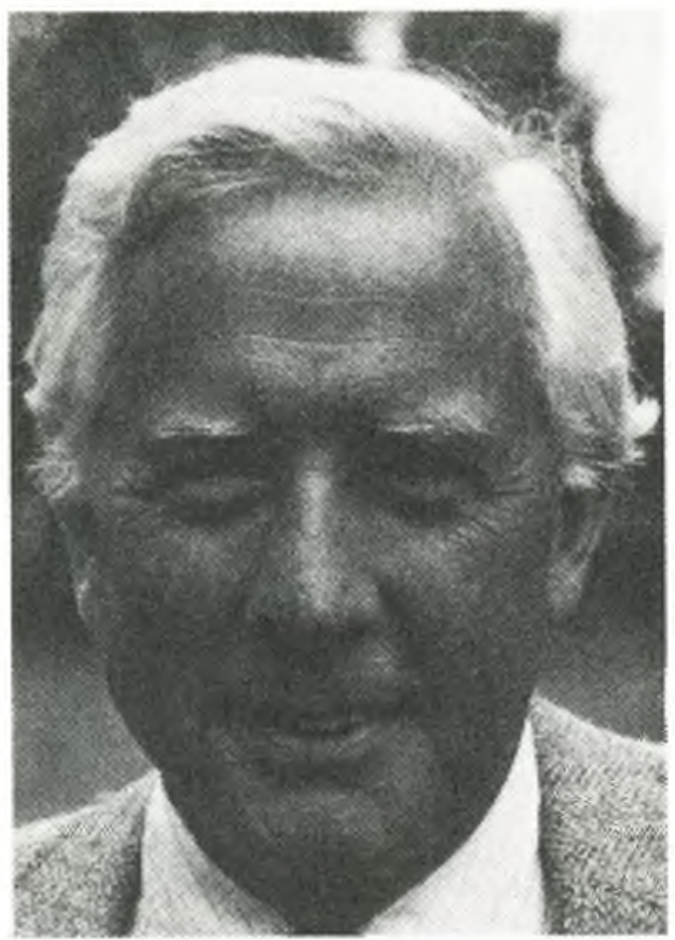

David McCullough

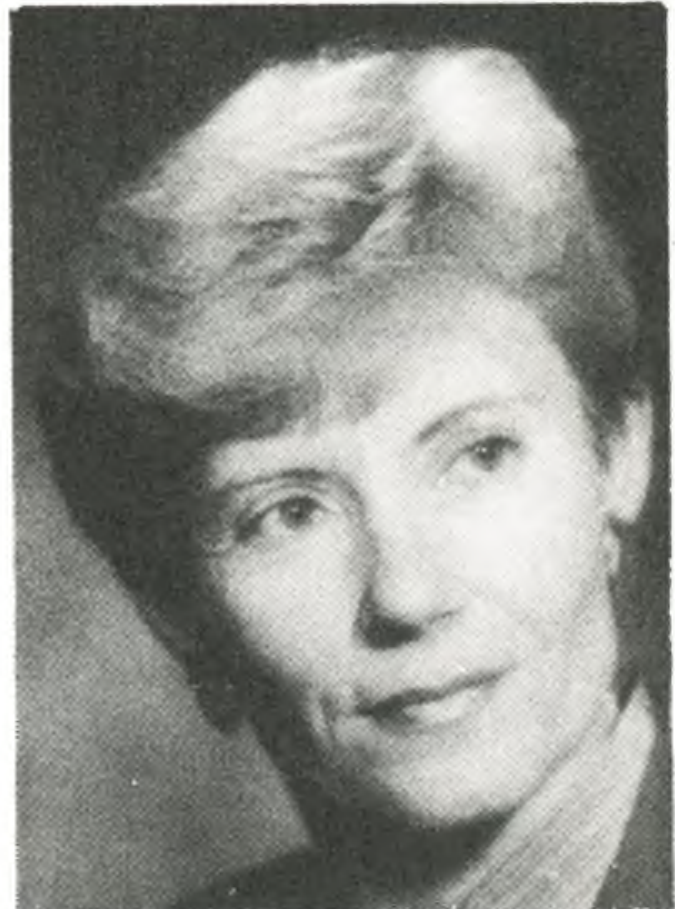

Barbara S. Uehling

\section{Theme Sessions}

The theme speakers on "Energies for Transition" have been described fully in the October and December 1985 issues of C\&RL News. Briefly, they are:

Maya Angelou, author of the autobiographical novel I Know Why the Caged Bird Sings, poet, playwright, professional stage and screen performer, and singer, will offer her view on transitions in American life.

Robert F. Asleson, president of International Thomson Information, Inc., will speak on trends in publishing.

Alan C. Kay, Research \& Development, Apple Computers, will give his personal perspective on technological changes, personal computing, and artificial intelligence.

David McCullough, prizewinning historian and host of the PBS series "Smithsonian World," will speak from the perspective of a scholarly consumer of library collections and services and will help identify transitions in American Society.

Barbara S. Uehling, chancellor and professor of psychology at the University of Missouri, Columbia, will speak from the perspective of an administrator in higher education.

An additional theme session will be a discussion held by a panel composed of three experienced researchers and three new researchers. The new researchers will have prepared a list of concerns and questions about doing research and will pose these to the experienced researchers. The goal is to answer questions about doing research and to offer encouragement to potential researchers. Moderator of the panel discussion will be Steve Stoan, ACRL Committee on Research Development, head of reference at Wichita State University.

A Wrap-Up Session will summarize ACRL's energies and events on the final day of the conference. 


\section{Conference schedule}

\section{Monday, April 7}

9:00 a.m. $-5: 00$ p.m.

8:00 a.m. $-3: 30$ p.m. 9:00 a.m. $-5: 00$ p.m. 12:00 noon-5:00 p.m.

8:00 a.m. $-7: 00$ p.m. 5:00 p.m. $-7: 00$ p.m. 8:00 a.m. $-5: 00$ p.m. 9:00 a.m.-12:00 noon 9:00 a.m.-12:30 p.m. 1:00 p.m. $-2: 30$ p.m.

2:45 p.m. $-4: 00$ p.m. 4:00 p.m. $-5: 00$ p.m. 5:00 p.m. $-7: 00$ p.m. 9:30 p.m.-11:30 p.m.

8:00 a.m. $-5: 00$ p.m. 9:00 a.m. $-5: 00$ p.m. 8:00 a.m. $-5: 00$ p.m. 8:30 a.m. $-9: 45$ a.m. 10:00 a.m.-11:00 a.m.

11:15 a.m.-12:00 noon 12:00 noon-2:00 p.m. 2:00 p.m. $-3: 00$ p.m.

3:15 p.m. $-4: 00$ p.m. 4:00 p.m. $-5: 00$ p.m. 4:00 p.m. $-6: 00$ p.m. 7:00 p.m.-11:00 p.m.
Continuing Education courses

\section{Tuesday, April 8}

Library Tour: National Agricultural Library

Continuing Education courses

Library Tour: Library of Congress

\section{Wednesday, April 9}

\section{Conference Registration}

Exhibits

Placement

Baltimore City Tours

Library Tours: Maryland Historical Society and George Peabody Library

Opening Session: Introduction by H. Joanne Harrar, Conference Chair

Welcoming Remarks by Sharon A. Hogan, ACRL President

Theme Session I: Alan C. Kay, Research \& Development, Apple Computers Presiding: Mary Sue Farrell, The Faxon Company

Contributed Papers Session I

New Products Seminars

Exhibit Opening and Reception

Reception: Enoch Pratt Free Library

\section{Thursday, April 10}

Placement

Exhibits

Conference Registration

Contributed Papers Session II

Theme Session II: Maya Angelou, Author, Poet, Educator

Presiding: Carla J. Stoffle, Associate Director for Public Services, University of Michigan

Contributed Papers Session III

Exhibits Only (free time)

Theme Session III: Barbara S. Uehling, Chancellor, University of MissouriColumbia

Presiding: Millicent Abell, University Librarian, Yale University

Contributed Papers Session IV

New Products Seminars

Library Tours: University of Maryland Law and Health Sciences Libraries Reception: National Aquarium 


\section{Friday, April 11}

8:00 a.m. $-5: 00$ p.m.

8:00 a.m. $-5: 00$ p.m.

9:00 a.m. $-2: 00$ p.m.

8:30 a.m. $-9: 45$ a.m.

9:00 a.m.-11:00 a.m.

10:00 a.m.-11:00 a.m.

11:15 a.m.-12:00 noon

12:00 noon-2:00 p.m.

2:00 p.m.-3:00 p.m.

3:15 p.m. $-4: 30$ p.m.

4:31 p.m.-
Conference Registration

Placement

Exhibits

Contributed Papers Session V

Informal Library Tours

Theme Session IV: ACRL Research Development Committee, Stephen Stoan, Head of Reference, Wichita State University

Presiding: Sharon J. Rogers, University Librarian, George Washington University

\section{Contributed Papers Session VI}

Exhibits Only (free time)

Theme Session V: Robert Asleson, President, International Thomson Information, Inc.

Presiding: Joanne Euster, Director, San Francisco State University Library

Contributed Papers Session VII

Free evening out in Charm City; see Tour Information for two suggestions.

\section{Saturday, April 12}

8:30 a.m. $-9: 45$ a.m.

Contributed Papers Session VIII

10:00 a.m.-11:00 a.m.

Theme Session VI: David McCullough, Host of Smithsonian World Presiding: David Weber, Director, Stanford University

11:15 a.m.-12:00 noon Wrap Up Session

1:00 p.m.-5:00 p.m. L Library Tour: Prince George’s Community College

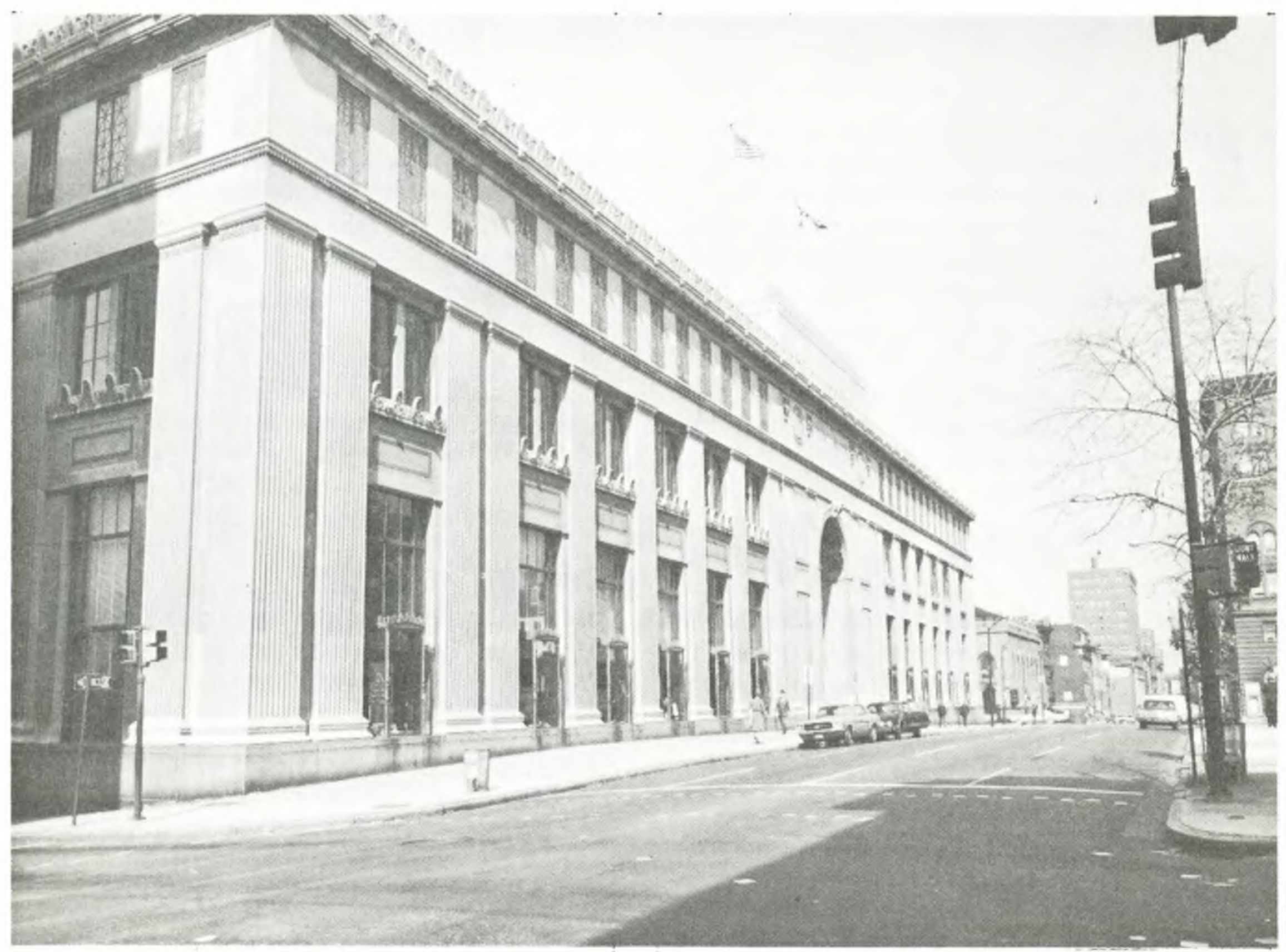

The Enoch Pratt Free Library, site of ACRL's Wednesday night reception. 


\title{
CONFIDENTIAL U.S. STATE DEPARTMENT CENTRAL FILES
}

\author{
INDOCHINA • CHINA • JAPAN • GREAT BRITAIN \\ THE SOVIET UNION • GERMANY • NICARAGUA • CUBA \\ EL SALVADOR • HONDURAS • PALESTINE-ISRAEL • IRAN \\ EGYPT •IRAQ • LEBANON • SAUDI ARABIA
}

University Publications of America takes great pride in announcing a documentary series of immense research significance: the publication of substantial - often complete - files of the papers of the U.S. State Department. Dwarfing the State Department's very selective Foreign Relations of the United States (which concentrates primarily on U.S. relations with individual nations but not on many of the other key topics that make up the majority of the original files), our ongoing series publishes the largely unabridged State Department records that are the definitive source of American diplomatic reporting on political, military, social, and economic developments throughout the world in the twentieth century. In cooperation with the National Archives and Records Administration, UPA has microfilmed over 3 million pages of Central Files and is publishing them for the first time. The files on South Africa are described below.

\section{SOUTH AFRICA: INTERNAL AND FOREIGN AFFAIRS, 1945-1954}

\begin{abstract}
UPA's new publication of the State Department's complete files on South Africa for 1945-1954 is a timely collection about a crucial decade in South Africa's recent history. These files constitute a very important research tool for scholars and students at all levels. I recommend the purchase of this extremely valuable resource.
\end{abstract}

\author{
—Dr. Robert L. Tignor \\ Department of History \\ Princeton University
}

$\mathbf{T}$ he major developments in South Africa during the years 1945 through 1954 were more than a mere foreshadowing of the current troubled conditions in that country. The tentative reformism of the early postwar period was swept aside in 1948 by the electoral victory of the Afrikaner National Party, and consolidation of power by the Nationalists was marked by the establishment of an official policy of apartheid and by the government's ability to overcome internal and external opposition to this policy. Knowledge of these developments is crucial to an understanding of South Africa today.
For researchers interested in the political, economic, and social history of South Africa, the State Department Central Files on South Africa-now published for the first time - offer a vast wealth of untapped primary materials. Our convenient microfilm edition makes available over 35,000 pages of special reports on political affairs, documents and analyses relating to apartheid and other racial issues, interviews and minutes of meetings with government officials, court proceedings and other legal documents, and countless high-level government documents.

Ordering Information

Confidential U.S. State Department Central Files.

South Africa: Internal and Foreign Affairs, 1945-1949. South Africa: Internal and Foreign Affairs, 1950-1954. $35 \mathrm{~mm}$ microfilm ( 14 reels) with printed guide.

Price: \$950. ISBN 0-89093-683-8.

Available now.

$35 \mathrm{~mm}$ microfilm (22 reels) with printed guide.

Price: \$1,550. ISBN 0-89093-684-6.

Available now.

\section{UNIVERSITY PUBLICATIONS OF AMERICA}

Dept. A-ARCL186 44 North Market Street Frederick, MD 21701

Call Toll Free 1-800-692-6300

Please visit us at Booths \#416 and \#418. 
RESEARCH COLLECTIONS IN WOMEN'S STUDIES

General Editors: Drs. Anne Firor Scott and William H. Chafe, Duke University

\title{
Papers of the League of Women Voters, 1918-1974
}

Advisory Editor: Dr. Susan Ware

\begin{abstract}
Scholars concerned with the history of women in twentieth-century America should rejoice at the availability of the Papers of the League of Women Voters. These records will enrich our understanding of the "woman citizen" and enhance research on a wide range of topics, including the efforts of women reformers to enact their programs through political education and in open networks organized for action.
\end{abstract}

\author{
-Dr. Pat King, Director \\ The Schlesinger Library \\ Radcliffe College
}

Ordering Information

Papers of the League of Women Voters, 1918-1974.

Part I. Meetings of the Board of Directors and the

Executive Committees: Minutes and Related

Documents, 1918-1974.

$35 \mathrm{~mm}$ microfilm (14 reels) with printed guide.

Price: \$900. Available now.

Part II, Series A. Transcripts and Records of National Conventions, 1919-1944, and of General Councils, 1927-1943.

$35 \mathrm{~mm}$ microfilm (20 reels) with printed guide.

Price $\$ 1,300$. Available now.
Part II, Series B. Transcripts and Records of National Conventions, 1946-1974, and of General Councils, 1945-1973.

$35 \mathrm{~mm}$ microfilm (30 reels) with printed guide. Price: \$1,900. Available now.

Part III, Series A. National Office Subject Files, 1920- 1932.

$35 \mathrm{~mm}$ microfilm (25 reels) with printed guide. Price: \$1,750. Available now.

\section{BLACK STUDIES RESEARCH SOURCES}

General Editors: Drs. August Meier and Elliott Rudwick, Kent State University

Recommended for libraries aiming at comprehensive collections in civil rights and black history.

-Choice

The Martin Luther King, Jr., FBI File. $35 \mathrm{~mm}$ microfilm (16 reels) with printed guide. Price: $\$ 950$.

Federal Surveillance of Afro-Americans (1917-1925): The First World War, the Red Scare, and the Garvey Movement.

$35 \mathrm{~mm}$ microfilm (25 reels) with printed guide. Price: $\$ 1,700$.

Black Workers in the Era of the Great Migration, 1916-1929.

$35 \mathrm{~mm}$ microfilm (25 reels) with printed guide. Price: $\$ 1,700$.

Papers of John and Lugenia Burns Hope. $35 \mathrm{~mm}$ microfilm (21 reels) with printed guide. Price: $\$ 1,250$.
New Deal Agencies and Black America. $35 \mathrm{~mm}$ microfilm (25 reels) with printed guide. Price: $\$ 1,500$.

President Truman's Committee on Civil Rights. $35 \mathrm{~mm}$ microfilm (10 reels) with printed guide. Price: $\$ 620$.

Papers of the NAACP.

Part 1: Meetings of the Board of Directors, Records of Annual Conferences, Major Speeches, and Special Reports, 1909-1950.

$35 \mathrm{~mm}$ microfilm (28 reels) with printed guide. Price: $\$ 1,700$.

Part 2: Personal Correspondence of Selected NAACP Officials, 1919-1939.

$35 \mathrm{~mm}$ microfilm (20 reels) with printed guide. Price: $\$ 1,200$.

Our Black Studies catalogue is available upon request.

UNIVERSITY PUBLICATIONS OF AMERICA

Dept. A-ARCL186 44 North Market Street Frederick, MD 21701

Call Toll Free 1-800-692-6300

Please visit us at Booths \#416 and \#418. 


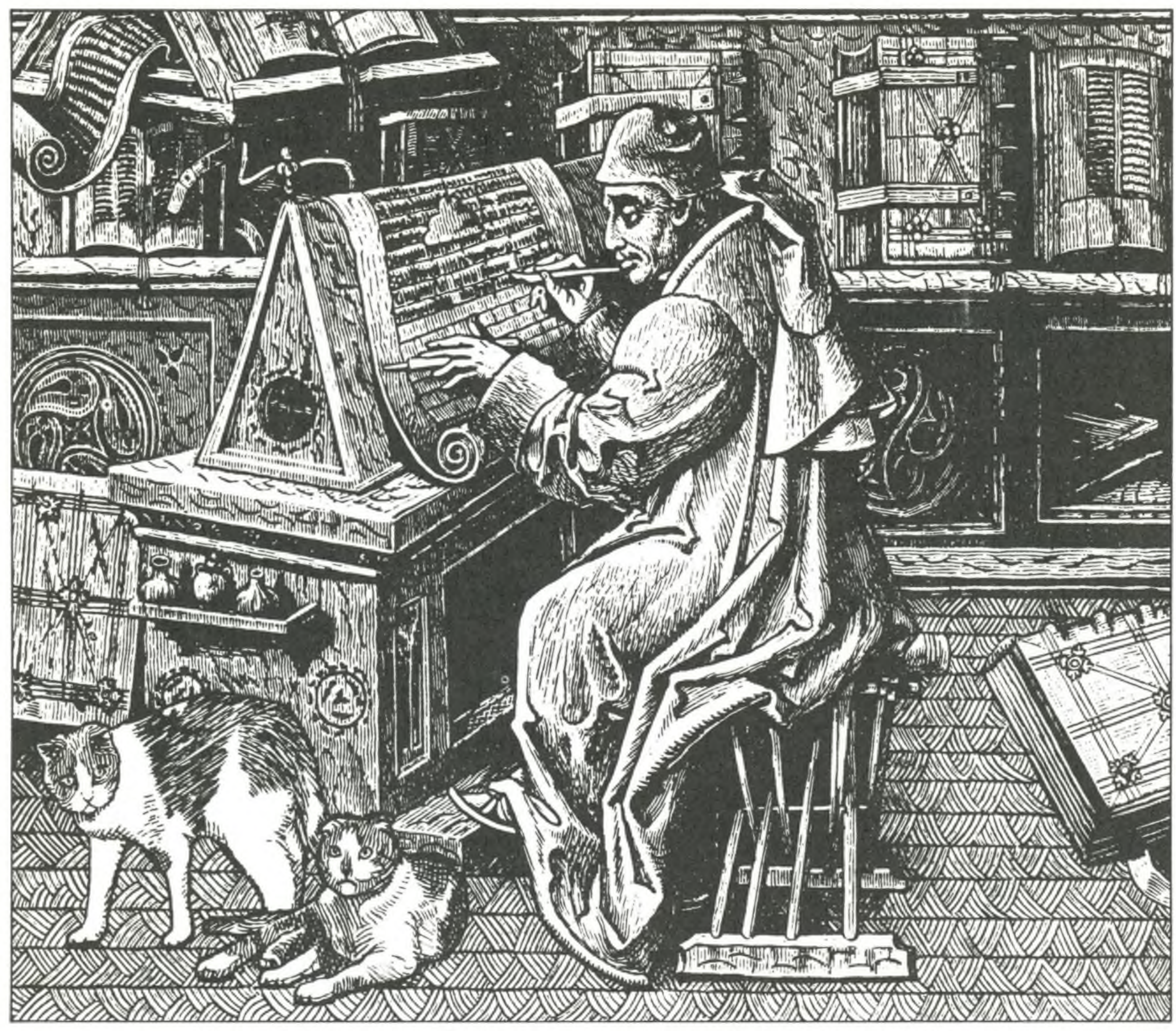

\section{We've taken book ordering out of the Dark Ages.}

BaTaSYSTEMS ${ }^{\mathrm{TM}}$ is Baker $\&$ Taylor's newest generation of electronic book ordering services. It's especially designed to work with existing computer hardware with built in flexibility that allows you to match the level of service to your library's unique needs.

Whichever service level you choose, you'll save time reduce paperwork and speed book acquisitions-all at a lower cost. For example:

ORDER allows you to order books through your personal computer, using a modem and regular telephone lines. Just enter the ISBNs and the following day you'll receive electronic confirmation from which you can print order slips. All calls are toll free. You also save the cost and delay of postal delivery.

Or you can choose SEARCH AND ORDER. In addition to electronic ordering, this service gives you quick access to Baker \& Taylor's diverse and comprehensive database of over 800,000 title records. It's your single source for virtually all the titles published or distributed in the United States. And you eliminate manual searching and purchase order typing.

Finally, BaTaSYSTEMS ACQUISITIONS offers on-line access to our database and electronic ordening plus a complete software package with fund accounting and full reporting functions.

These advanced service technologies are typical of how Baker \& Taylor stays in step with the times, building on our experience to bring you the latest in library services.

BaTaSYSTEMS. It's nothing less than a renaissance in book acquisitions.

Write or phone today

for more information

EXPERIENCE YOU CAN DEPEND ON

BAKER \& TAYLOR

a GRACE company

Eastem Division, 50 Kirby Avenue, Somerville, NJ 08876 (201) 722-8000 Midwestern Division, 501 S. Gladiolus Street. Momence. IL. 60954 (815) $472-24+4$ Southern Division, Mt. Olive Road, Commerce. GA 30599 (40+) 335-5000～Westem Division, 380 Fdison Way: Reno. NV' 89564 (702) 786-6700 


\section{Contributed Papers}

Eight time slots have been scheduled for the presentation of contributed papers. Fifty-one papers and nine idea briefs were selected following a blind reviewing process. All papers will be paired by subject matter and all papers will be repeated. The papers will be published in the conference proceedings. The abstracts of the papers selected for presentation are listed here for your convenience and information.

\section{ACADEMIC/RESEARCH LIBRARIANSHIP}

Resolved: Library Schools Do Not

Meet Their Goals and Objectives in Training

Academic Librarians to Perform Research

\section{David G. Anderson}

Christina Landram

Georgia State University

Since academic librarians have gained faculty status, they must meet the same criteria for promotion and tenure as other faculty members. These criteria include research togteher with job performance and service. The paper takes the position that library schools in the United States do not meet their stated goals and objectives in regard to training librarians for entry level academic positions. Current library school catalogs are examined for their statements of goals and objectives and these are then compared to courses taught in research and statistical methods as well as the availability of a thesis option.

\section{The Academic Library's Changing Role IN THE UNIVERSITY SETTING \\ Stephen E. Atkins \\ University of Illinois at Urbana-Champaign}

The academic library survived the university financial difficulties in the 1970 s with the certainty that the library would be vulnerable during the university's next financial downturn. Unless libraries and librarians improve their political base within the university the next period of financial shortfall will damage the library. A solution is for librarians to play an active role in university governance, but this means that librarians have to be considered equal to the teaching faculty. Only in this way can the library be protected from those administrators who consider the library a bottomless pit for funds.

Freedom of AcCess to Information in Machine Readable Form: The Librarian's Role

$$
\begin{aligned}
& \text { Samuel Demas } \\
& \text { Cornell University }
\end{aligned}
$$

In exploiting the incredible potential of new technologies for improving information access, we must not overlook their potential for restricting freedom of access to information. As powerful economic forces define the dynamics of the emerging information society, information is increasingly handled and regulated as a commodity rather than as an entitlement. The author believes the question of access to information in machine-readable form is one of public policy as much as it is one of economics. As with our societal role in intellectual freedom issues, librarians have a unique and property struggle. This paper outlines the potential threat to freedom of information access, and describes the role librarians should play in defining the changing patterns of information access which result from new technologies.

\section{Curriculum Change: Transitions in TIME \\ Michael Haeuser Gustavus Adolphus College}

Recent publications and articles that have received national attention focus on the problems that face higher education as well as allegations that American colleges and universities were "failing to give students an adequate general education." The critics are correct and considerable energy is being directed to returning higher education to its traditional path. Examples should be found of library participation in curriculum review. Indeed librarians should vigorously support efforts to curb the discredited marketplace philosophy of education.

\section{ACADEMic Library Censorship in a Conservative Era \\ Elizabeth Hood Trinity University}

There is a sense that the censorship question is a moot point in academic libraries, where support of curriculum and research interests are deemed the primary responsibility of the library. However, studies of censorship have almost completely ignored the attitudes of academic librarians. An informal survey of the staff of one medium-size college library revealed that personal agreement with controversial material was influential in determining selection. If this observation is accurate for most academic librarians, a conservative political climate and less affluent circumstances could bring an increase in the incidence of self-censorship.

The Benefits of Research for Academic Librarians and the Institutions Which They SERVE

Dale S. Montanelli

Patricia S. Stenstrom

University of Illinois at Urbana-Champaign 


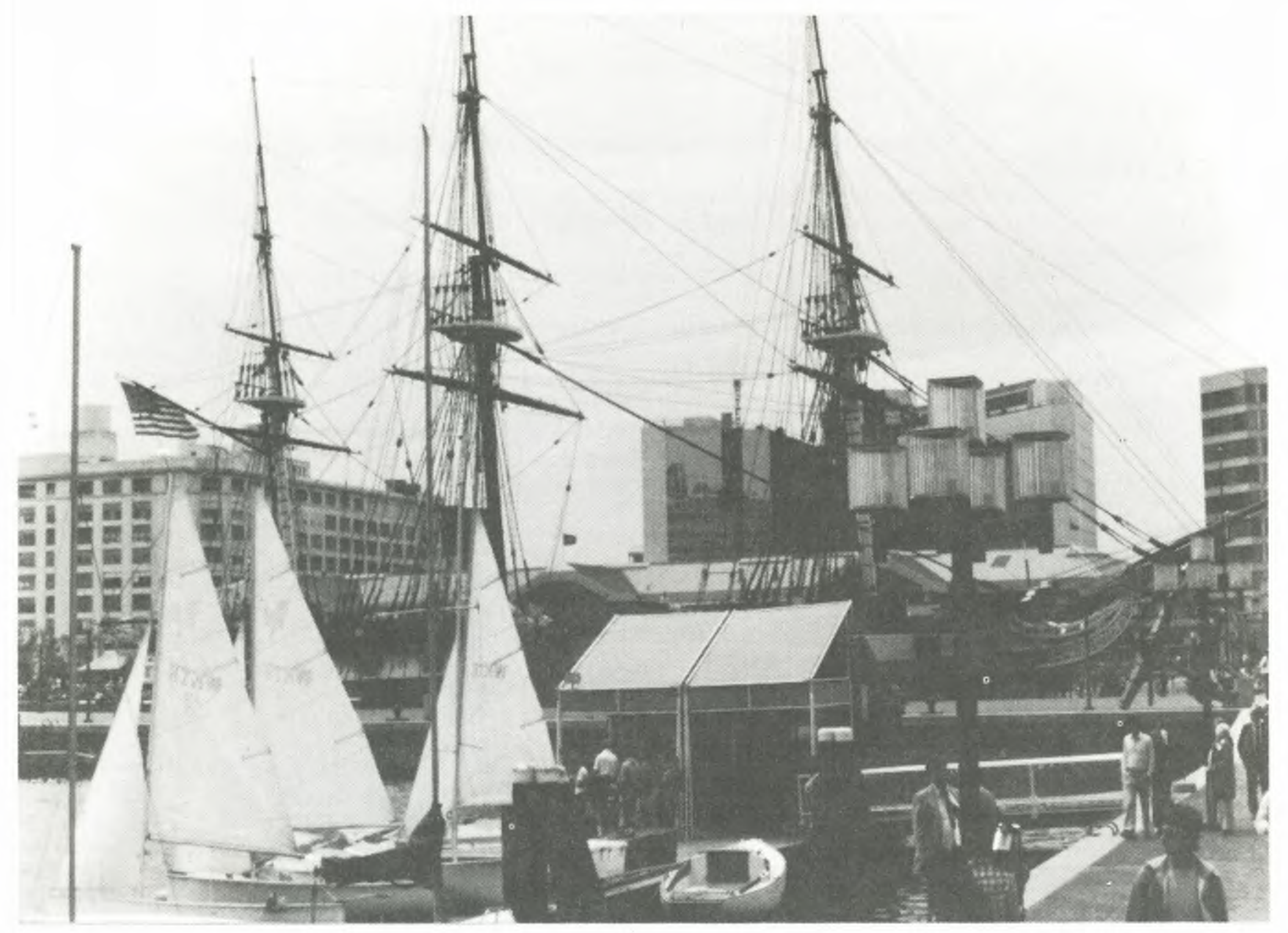

Rigging of the "USS Constellation," with McCormick \& Co. (left) and the new Hyatt Regency Hotel (center right) in the background.

Although some academic librarians, administrators, and teaching faculty have expressed concern that librarians cannot or should not do research, there is a growing body of literature which supports research by librarians as carrying significant benefits both to the individual librarian and to the institution served. The benefits of research include job advancement, personal recognition when no advancement is possible, improved relationships with teaching faculty, increased responsiveness to change and innovation, and better library service through shared knowledge and experience.

\section{Online SEARChing ANd the Research Process}

\section{Patricia Tegler}

Constance Miller

University of Illinois at Chicago

Under the dominating influence of the concepts of recall and precision, online database searches have been evaluated in terms of the characteristics of the bibliographies they produce. This static, product-oriented approach ignores the interactive potential of online files and places online searching outside of the organic and creative aspects of the research process. The relevance of online databases, and of the information specialists who use them or teach others to use them, to the process of research depends upon their ability to contribute to a trialand-error reformulation of problems under investigation.
Another paper on Academic/Research Librarianship is:

Mary Ann Griffin, "Managing Values in an Academic Library," (under Administration).

\section{ADMINISTRATION}

\author{
The Development Team \\ Dwight F. Burlingame \\ Bowling Green State University
}

The need for additional resource development for academic libraries is recognized. One way to proceed is by developing a team approach with the development office on campus. Principles of team play in the development context are received as well as other approaches libraries can utilize to enhance their fund-raising efforts.

Financing Academic Libraries: Making the

Transition from Enrollment Growth to

QuALITY ENHANCEMENT

John M. Cooper

Harvard Graduate School of Education

Recent studies addressing virtually every aspect of the quality of higher education have raised expectations for improving colleges and universities. Translating expectations into action requires resources, and providing adequate funds for maintaining and improving the quality of academlc libraries will require changes in the structure and use of funding formulas. Many library formulas 
are enrollment-driven making library funding vulnerable to stable or declining enrollment. Some states have used cost studies and ACRL library standards to design formulas that deemphasize enrollment. Redesigning funding methods to recognize fixed costs changes the underlying premise from one that funds should flow from enrollment growth to one linking funding with programmatic changes. The next challenge is to add factors that reward successful management and enhance the quality of libraries.

\section{Managing Values in an Academic Library}

\section{Mary Ann Griffin Villanova University}

Developments in technology, in organizational structure, and in higher education are placing increasing demands on library managers. The library director, once primarily concerned with finances, and the management of collection, staff, and facilities, must increasingly be concerned with the articulation of values. The author recommends that the formulation and promulgation of a value system is essential to organizational success.

\section{ACADEMIC LibraRIANs' WoRKLOAD}

\section{Eileen E. Hitchingham Oakland University}

As new responsibilities are added to traditional ones performed by academic librarians, knowledge of how we expand our time becomes important. Time analysis is one way to get a better handle on library priorities in regard to staff resources. This paper gives "snapshot" results of a 7-day period in an academic library. A comparison is made with faculty in science and social science disciplines.

\section{Strategies for Change \\ Michael D. Kathman \\ Carol P. Johnson \\ St. John's University}

Change is an inescapable part of the automation process, and any change has the potential for a constructive or destructive effect on the library organization. Change is accompanied by fears, both realistic and unrealistic, which must be dealt with during all stages of the automation process. As a result, any library considering an online system needs to be aware of the effects of change and consider the human factors in its planning process. This paper details the Joint Library's experience with anticipated and unanticipated changes occurring during the planning stages for automation.

\section{A Library Research Application of Focus Group INTERVIEWS

$$
\text { Meg Scharf }
$$$$
\text { Jeannette Ward }
$$ \\ University of Central Florida}

In order to obtain a direction and set priorities for programs to improve library services, an accepted marketing research method was adapted for library application. The Focus Group is a marketing research method of conducting an in-depth interview with a small group to gain insight into consumer needs, problems, attitudes, and behaviors. The components of a Focus Group interview, and the implementation in an academic setting are described. The results of the interviews were used to gain insights, develop ideas, direct and generate hypotheses, and target areas for more structured surveys and studies.

Another paper on Administration is:

Elaine McPheron, "User Demand for Library Services: An Undergraduate Library Model," (under Readers' Services).

\section{BIBLIOGRAPHIC CONTROL/ CATALOGING}

Handling of Serials in Micro-Reproduction: Single Bibliographic Record/Multiple

FORMATS-

An Ohio State University Experience

$$
\begin{gathered}
\text { Marjorie E. Adams } \\
\text { Daphne C. Hsueh } \\
\text { Ohio State University }
\end{gathered}
$$

This paper describes the problems created by the national policy for cataloging multiple formats of a serial title, in which the format of a work is emphasized over the content. It details a solution successfully practiced for five years in an academic library's online catalog which lists together, under a single title record, all holdings of a serial regardless of format. It further proposes a departure from traditional bibliographic description and advocates the concept of describing the intellectual content in the primary record with attached records showing physical formats and detailing holdings.

\section{Error Detection in Bibliographic Records: Can the Computer Do It All? \\ Jaye Bausser \\ Duke University \\ Jinnie Y. Davis \\ North Carolina State University \\ David Gleim \\ University of North Carolina at Chapel Hill}

The authors explore the shifting roles of automatic and manual error detection during the transition from card to online bibliographic catalogs. Using the TRLN validation system as an example, the authors find that existing automatic systems cannot detect all important errors. They suggest that greater sophistication of automatic error detection will be needed as online systems develop. The authors describe the impact on catalog management activities as the balance between manual 
and automatic error detection shifts in favor of the computer.

\section{Going Public: Born Again \\ Cataloging in the Online Networks \\ Ruth Hafter \\ Sonoma State University}

Participation in an online network means that the work of individual libraries and their catalogers becomes visible to, and utilized by, many other libraries. Network affiliated libraries and network quality control personnel thus become participants in evaluating each cataloger's work. Results of a 1983-84 case study of six academic libraries indicate that the shift from in-house to nationwide evaluation of catalogers' records creates enhanced status and influence for cataloging peer groups and provides both networks and individual libraries new opportunities to identify master catalogers by online inspection of their work.

\section{Access Points and Book Use: Does the Catalog Record Make a Difference?}

Gunnar Knutson University of Illinois at Chicago

This study builds on limited past research on correlations between catalog access points and circulation. The study examines 1105 catalog records in three LC classifications and one subclass, comparing number and type of access points with number of circulations by type of user. Results show no significant positive correlation between total num- bers of subjects or other access points and total circulation. However, stronger correlations emerge when data are examined by type of subject and type of user. As we consider modifying or enhancing the catalog record, we must take into account differences in users and subject areas.

\section{Quality Control of Online Catalogs: Automation vs. Human Control}

\section{Ichiko Morita \\ Ohio State University}

Quality here is concerned with both the intellectual content as well as the description of the catalog. With the advent of the online catalog, we started automatic quality control, beginning with such activities as the detection of errors and duplicate entries. As computer technology advances, the speed and magnitude of the shift from manual to machine control is increasing. Automated quality control is no longer limited to the descriptions of catalog records but is extending to their intellectual contents as well. The extent to which automated quality control of intellectual content might be taken must be given serious consideration.

\section{BIBLIOGRAPHIC INSTRUCTION}

\section{CONCEPTS FOR BibliogRAPHIC INSTRUCTION} in This Time of Transition

Deborah Fink

University of Colorado

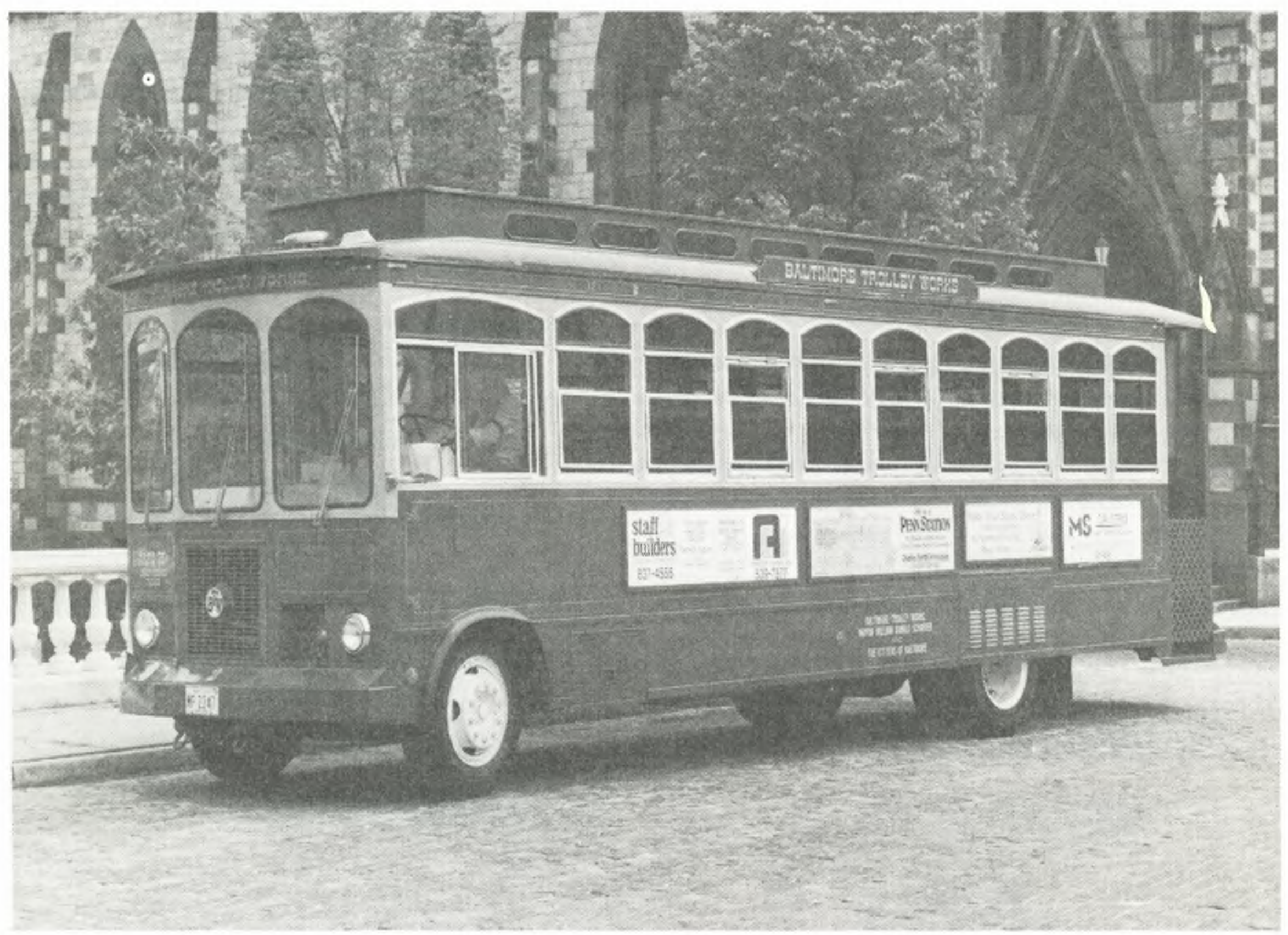

The new Baltimore Trolley is a replica of the old trolley cars of 50-60 years ago. 


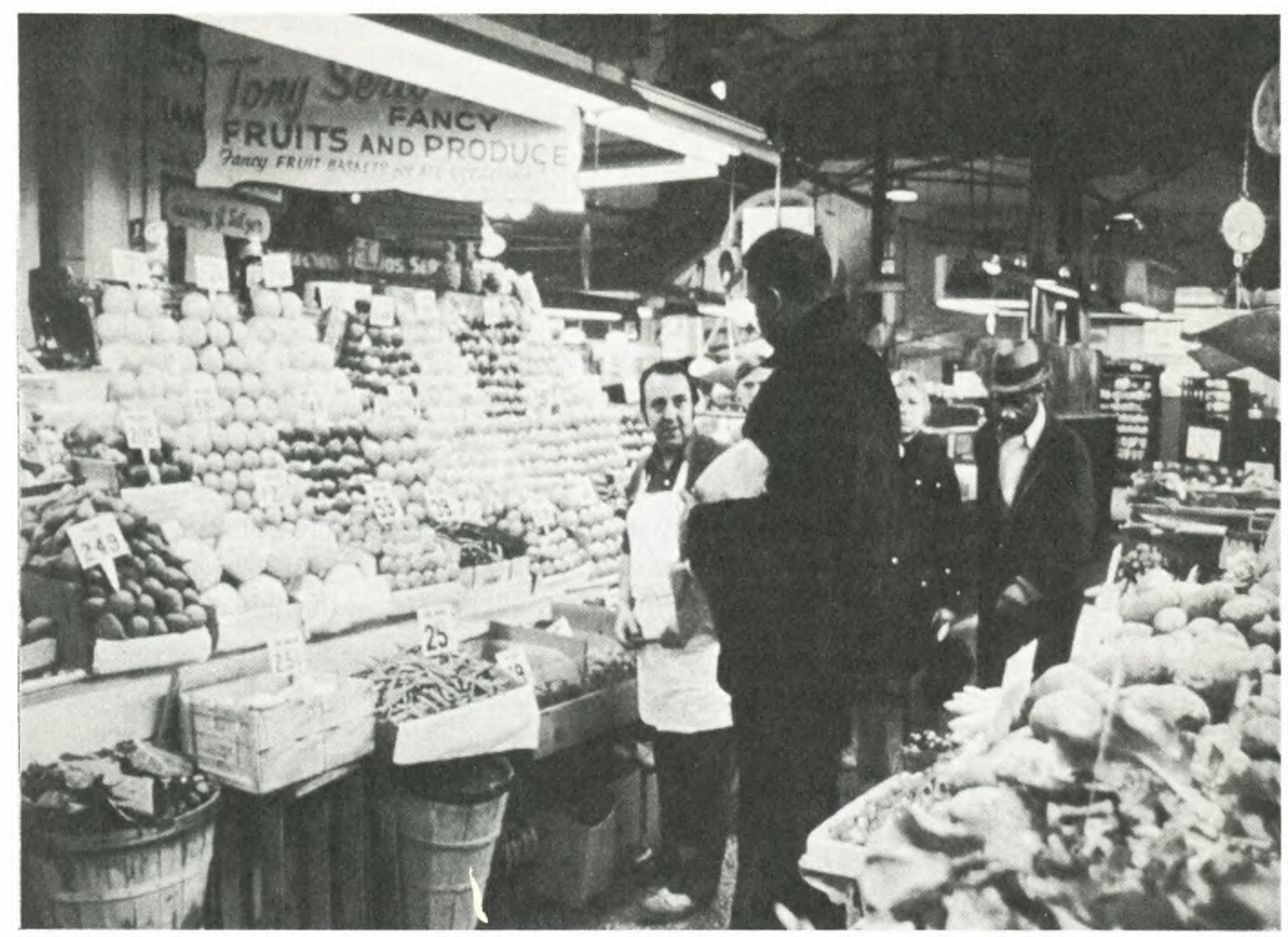

Interior of the Lexington Market, Baltimore.

The current transition of society to an information-based economy offers teaching librarians an opportunity to expand our conception of the library research process by introducing "information processing" in our instruction. Information processing is the operation which cycles information from communication to dissemination to acquisition and organization to access, manipulation and communication. A paradigm for this flow provides a conceptual framework for organizing and presenting the functions of authors, publishers, libraries, and researchers. The paradigm is also useful for exploring the political dimensions of information and to suggest strategies for integrating traditional and electronic modes of information access and manipulation.

\section{END-USER INSTRUCTION: What Are You Doing? \\ Sharmon H. Kenyon \\ Humboldt State University}

The purpose of this idea brief is to discuss wlth other librarians how they are dealing with the issue of end-user instruction. What, if any, kinds of programs do they have for faculty, staff, students, or community users? Is it part of the reguuar library instruction program? What are the staffing and equipment requirements? Do you think libraries should be doing this kind of instruction? The discussion will begin with a description of the instruction at Humboldt State University.
Teaching Microcomputer Literacy:

New Roles for ACademic Librarians

\section{Linda Piele \\ Judith Pryor \\ Harold Tuckett}

University of Wisconsin-Parkside

While microcomputer labs and software collections are increasingly a part of college and university libraries, most librarians are not instructing users in microcomputer literacy, despite the clear need of many users for such instruction. In many cases, librarians do not believe that it is their role to provide such instruction. This paper contends that it is indeed their role, and that if one views microcomputers as important tools for information retrieval and management, the librarian's role in teaching users about them is vital. By examining the experience of one academic library in assuming a central role in the administration of a microcomputer lab and in campus-wide microcomputer literacy instruction, changes in librarians' professional roles are suggested, and the implications of such a role are examined.

The Effect of an End-User Training Program on an Online Search Service

Judith G. Robinson

Julia R. Shaw

Virginia Commonwealth University

University Library Services of Virginia Com- 


\section{Featuring the finest \\ in reference works for academic libraries...}

\section{KRAUS \\ INTERNATIONAL PUBLICATIONS}

For over a decade, under the imprints of Kraus-Thomson, KTO Press, and, since January 1, 1980, Kraus International Publications, we have produced a steadily growing number of single and multi-volume reference works in the humanities and social sciences, as well as anthologies and archival collections of significant research value.

Come visit our booth at the ACRL Conference. Among the many fine works we will have on hand for your appraisal are:

\section{WRITINGS ON AMERICAN HISTORY, 1962-73:} A SUBJECT BIBLIOGRAPHY OF BOOKS AND MONOGRAPHS. Compiled jointly by Kraus International Publications and the American Historical Association.

10 vols. White Plains, NY 1985 . \$1,300.00

\section{GUIDE TO THE STUDY OF UNITED STATES HISTORY OUTSIDE}

THE U.S., 1945-1980.

General Editor: Lewis Hanke.

Under the sponsorship of the American Historical Association and the University of Massachusetts (Amherst).

5 vols. White Plains, NY 1985 . \$418.00

THE SIMON WIESENTHAL CENTER ANNUAL, Volume 2.

Edited by Henry Friedlander and Sybil Milton.

Published in cooperation with The Simon Wiesenthal Center.

White Plains, NY 1985. $\$ 30.00$ (available on standing order)

\section{THE FILM INDEX: A BIBLIOGRAPHY.}

Vol. 2, The Film as Industry.

Vol. 3, The Film in Society.

Compiled by workers of the Writers' Program, Work Projects

Administration in the City of New York. Published in

cooperation with the Museum of Modern Art, New York.

2 vols. White Plains, NY 1985. $\$ 180.00$

Please direct orders and inquiries to:

\begin{tabular}{l}
\hline Kraus International Publications \\
\hline A Division of Kraus-Thomson Organization Limited \\
One Water Street \\
White Plains, New York 10601 \\
Tel. (914)-761-9600
\end{tabular}


monwealth University began an end-user training program in February of 1985 at Tompkins-McCaw Library on the Medical College of Virginia Campus. In order to determine any changes in the number and type of searches submitted to the Library's Search Service due to the End-User Program, the use of the service by each trainee is being studied. Any computer searches requested by the end-user during the past two fiscal years have been reviewed. Now that end-user training is a reality in libraries, speculation as to its effect can and should be replaced by efforts to obtain concrete figures. Models and means for obtaining these results are now open for discussion.

Other Bibliographic Instruction papers will be found under Readers' Services:

Barbara E. Kemp, Mary M. Nofsinger, and Alice M. Spitzer, "Building a Bridge: Articulation Programs for Bibliographic Instruction."

Karen F. Smith, "Robot at the Reference Desk?"

\section{COLLECTION DEVELOPMENT / MANAGEMENT}

\author{
Computer Accessible Material in the
}

ACademic Library: Avoiding the Kludge

$$
\begin{gathered}
\text { Katherine S. Chiang } \\
\text { Cornell University }
\end{gathered}
$$

Computer accessible material should be an integral part of an academic library collection. This paper discusses the issues to be considered when constructing a program for the collection and service of these new formats.

\section{A Model Interactive Automated ACQuisitions System \\ Colleen Cook \\ Texas A\&M University}

Over the past decade the bibliographic utilities, publishers and book vendors have designed and marketed acquisitions systems. Some libraries have developed local systems, while others have acquired an acquisitions package as one among several functions in a multi-purpose, integrated turnkey system. Each of these acquisitions systems has inherent strengths and weaknesses concomitant with the originator's major purpose in system design. But as yet no acquisitions system has fully satisfied the diverse needs of academic libraries in 1985. A model interactive acquisitions system is proposed that is locally-based, integrated into a multi-purpose automated system and interfaced with databases nationally for vendor availability, in print and bibliographic information.

Hardcopy in Transition: The Plan for a Prototype Automated Storage and Retrieval Facility for Low Use Library Materials at California State University, Northridge
Norma S. Creaghe

Douglas A. Davis

California State University, Northridge

California State University, Northridge, has submitted a building program for a new phase of its main library that includes a prototype of a large automated storage/retrieval system (AS/RS) capable of housing 950,000 volumes. It will be closely integrated with an advanced online catalog and circulation system. The final cost is estimated at $\$ 13,000,000$ less than a new building with conventional shelving and equal capacity. Our position is that an AS/RS is a practical, economical and innovative solution to the problems of constantly growing collections and escalating library construction costs. It will solve crowding problems while librarians assess and compare the many formats in which information will be available in the year 2000 and give them time to decide which ones to use and how to use them. The authors believe this large scale library test of a current technology, the AS/RS, would provide a wealth of important technical and functional knowledge regarding storage and use of low-use materials in academic libraries.

\section{Developing-World IMPRints IN ACADEmic Library Collections}

David L. Easterbrook University of Illinois at Chicago

This brief emphasizes the tremendous growth in both quality and quantity of social science scholarship in the developing world and highlights the need to focus expanded collection development energies on such publications in North American academic libraries outside of the traditional area studies collections. The internationalization of social science research calls for sensible responsive action or else our collections will become increasingly parochial during a period in which developing-world imprints become increasingly important to a broader constituency of readers.

\section{Assessing Collection Development Organization IN A Small ACADEmic Library Lynn Gamble California Polytechnic State University San Luis Obispo}

Assessing the collection development organization in a library is a task done more often than is generally realized. A planned study approach is available as part of the CAP program from the Association of Research Libraries and has been used by many large academic libraries. Another approach, outlined in this paper, advises a review of existing structures, acknowledging and correcting problems, making specific job descriptions and assessing the degree of interest in participating. The structure is then designed around the job to be done and the personnel available. This type of study is 
especially applicable to small academic libraries.

Beyond the Book: Collection Development and the Special Collections Librarian

Gretchen Lagana

University of Illinois at Chicago

The purpose of this paper is to examine energies for transition as they relate to special collections librarianship with attention focused on collection development. The role of "papers" collections and non-print materials is presented as an important component of special collections. The field of popular culture is cited as an example of the need for primary research materials in non-traditional fields.

Capturing the Mainstream: An Examination of Publisher-Based and Subject-Based Approval Plans in Academic Libraries

\section{Karen A. Schmidt} Robert G. Sewell

Approval plans in large academic research libraries have had mixed acceptance and success. Much of the negative reaction may be caused by not designing a plan suitable for the book market and the needs of research libraries. The author compares the viability of subject- and publisherbased plans for academic libraries in both domestic and international markets, and presents the case for the overriding success of the publisher-based plan for domestic publications, and subject-based plans for international markets. The intrinsic differences between the two types of plans are discussed, and the publishing industries of North America and Europe are reviewed for their impact on approval plans covering various countries. The experience of the University of Illinois-Urbana Library is presented as a specific case for the relative successes of both types of plans. The collection, the library organization, and the vagaries of the publishing industries of many countries form the basis for selecting the most economical plan.

Another Collection Development/Management paper is:

Celia Wall, "Liberal Arts Colleges, Online Searching, and Economic Survival" (under Readers' Services).

\section{FUND RAISING}

See under Administration:

Dwight F. Burlingame, "The Development Team."

\section{NETWORKING/ COOPERATION}

The Open System Interconnection As a Building Block in Electronic Networking

Richard W. Boss

Information Systems Consultants, Inc.

No aspect of library automation development

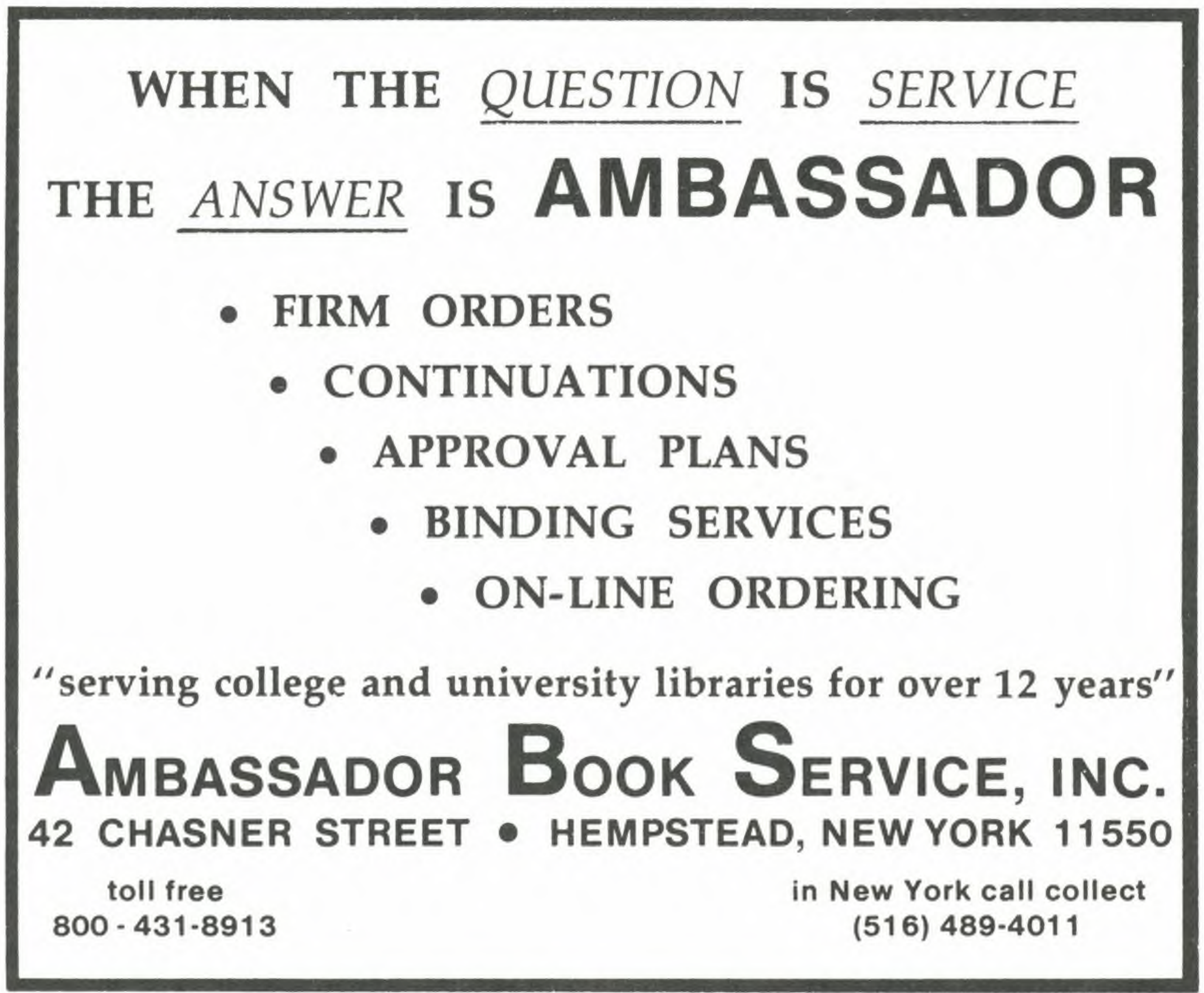




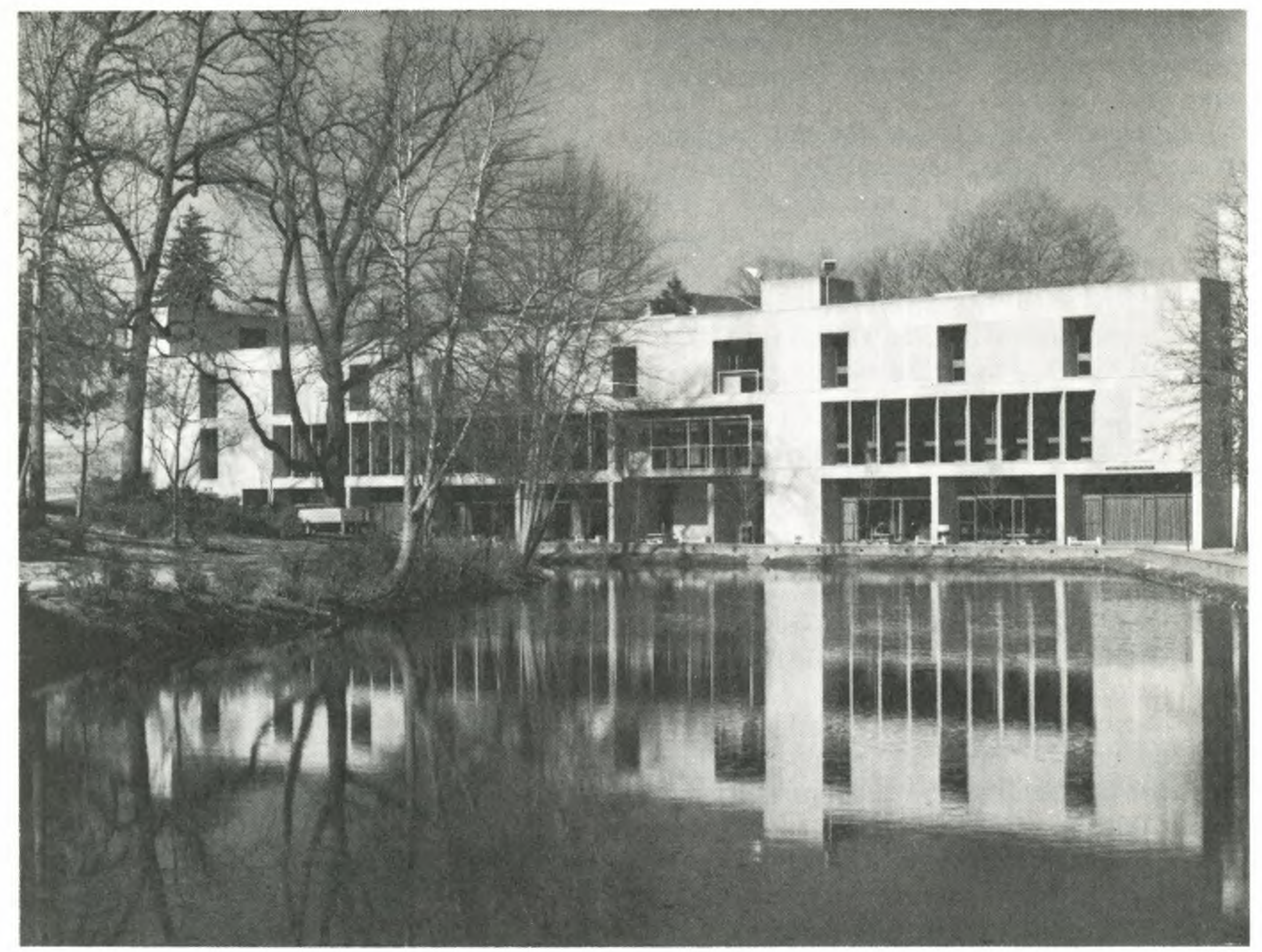

The Albin O. Kuhn Library \& Gallery, University of Maryland, Baltimore County.

appears to have stimulated as much discussion in the past year as networking, or the linking of different computer systems. There were more than a dozen presentations on the topic at the Annual Meeting of the American Library Association in 1985 and at least three vendors have announced networking products in the past year. Several presentations have been scheduled for this ACRL Conference. This paper discusses the Open System Interconnection Reference Model (the OSI), a framework within which standards are being developed for the linking of computer systems of all types, and being used for different applications. The author contends that the library community should develop its standards within the framework of the OSI so that library systems can link not only with one another but also with other systems in their organizations.

\section{Sharing Serial Collections}

Carol M. Kelley

Texas Tech University

Both serial acquisitions vendors and integrated library system vendors now offer serial control packages to customers. Will the technology for serials result in increased cooperative buying and lending among libraries? If so, what steps are necessary within each library to allow for this cooperation? What types of workflow changes are brought about after serials systems are installed? Will libraries be willing to share for cooperative collec- tion development?

Another Networking/Cooperation paper is:

Judith Adams, "The Clearinghouse for Curriculum Development in Bioethics: A Research Library Creates a Database and Services to Respond to the Emerging Need of Interdisciplinary Academic and Clinical Clientele" (under Special Collections).

\section{PERSONNEL}

The Plateaued Employee and The Manager's Role

James F. Comes

Ball State University

The theme of this paper is career development and the employee who cannot reasonably expect a promotion for an extended period of time. The concept of career is discussed and the career of the plateaued employee is described. The need for recognition and support of the effective plateaued employee is noted and several intervention strategies are suggested for the manager.

\section{Pay for Performance: THE TE*MS EXPERIMENT \\ Constance Corey Virginia Steel \\ Arizona State University}

Decisions concerning the award of merit money are often painfully difficult to make, especially 
when peer review is included in the process. This paper describes the implementation of an innovative merit evaluation system, $\mathrm{TE}^{*} \mathrm{MS}$, in the $\mathrm{Ar}$ izona State University Libraries. TE* MS (Team Evaluation and Management System) combines anonymous peer review of job-related behavioral characteristics (TE) with a management system (MS) in which supervisors evaluate the progress made by each librarian toward individual performance objectives. The paper includes a brief analysis of the positive and negative features of TE* MS as applied in an academic library.

\section{Job Design for the Automated Technical Services Environment}

\section{Kathleen M. Hays \\ Johns Hopkins University}

Automation has an impact on the work which we perform in the academic library technical services operation. Much research has been devoted to the effects of automation on industry, but technology is also changing the library workplace. The VDT, the primary medium of change, has been implicated as a factor in job-related stress. The scientific principles of job design first suggested by Charles Babbage and Frederick Taylor should be re-evaluated in light of more recent research. One way to relieve job stress is to redesign technical services jobs based on the sociotechnical model of job design, which attempts to balance social factors with technical considerations.

The Flow of Human Resources:

A Turnover Agenda for ACAdEMic Librarianship

\section{James G. Neal}

Pennsylvania State University

Despite a significant dependence upon human resources and the substantial costs of personnel replacement, academic libraries continue to operate without effective employee turnover management programs. An action and research agenda for individual libraries, ACRL and the academic library profession is recommended.

\section{A Library Middle Manager Looks at Performance Appraisal}

\section{Barbara P. Pinzelik \\ Purdue University}

A basic role of the library middle manager is to insure that the library support staff perform effectively. In carrying out the performance appraisal procedures required by most libraries, the inexperienced manager assumes that proper application of the process will solve the organization's personnel problems. More experienced managers have doubts about the effectiveness of performance appraisal, which they may attribute to their lack of skill. A search of the management literature reveals the depth and complexity of decades of research into the process. Some of the many variables which affect the validity and effectiveness of performance appraisal aie incorporated into a model for the middle manager.

\section{StafF Utilization in Branch Libraries: A Research RePort \\ Carolyn A. Snyder Stella Bentley \\ Indiana University}

The study reports the findings of a comparison of the perceptions of public services staff of utilization of their time and the actual recorded time utilization. There are significant differences between the estimated time and actual time spent on public services, collection development, and administrative activities by professional staff, and between technical services and administrative activities by paraprofessional staff. Research was funded by the Council on Library Resources and done in the Indiana University-Bloomington Libraries.

\section{TeChNical Services: \\ Public Services behind Closed Doors \\ Georgene A. Timko \\ Northeastern State University}

The theme "Energies for Transition" reflects the new atmosphere in technical services. Technical services has reached a transition point. Library literature indicates that it is not going to be replaced, integrated or phased out but that a stronger service orientation will be its new focus. This service philosophy will require us to work closely with our colleagues in public services. Communication, cooperation, and coordination must replace the traditional rivalry between technical services and public services for personnel, resources and the director's attention. This paper proposes that technical services need to conduct their own public relations program. Three suggestions are offered to help accomplish this program. First we must explain what we do and why we do it. Second, we should foster a "service to the public" attitude among the staff. Third, we must improve communication and coordination with public service departments.

\section{Suggested Guidelines for Salary

$$
\text { Linda Dugger }
$$$$
\text { Jeanie M. Welch }
$$$$
\text { Lamar University }
$$
Determination in an ACADEMic Library

For use in hiring and equity adjustments, the Library Faculty at Lamar University has constructed a suggested formula for professional salaries. The Salary Schedule Review Committee devised a suggested salary formula which included guidelines for determining the following salary criteria: 1) Base salaries (according to rank) based on other academic salaries at the parent institution, within the state, and nationally. 2) Percentage increments according to the following criteria: education beyond the MLS; previous professional academic library 
experience; areas of responsibility; skill requirements; unique expertise (discretionary); market considerations (discretionary). The Salary Schedule Review Committee also devised a worksheet to determine suggested salaries for every professional position.

Other papers on Personnel are:

Ruth Hafter, "Born Again Cataloging in the Online Networks" (under Bibliographic Control/Cataloging).

Eileen Hitchingham, “Academic Librarians' Workload." (under Administration).

\section{PUBLISHING}

See under Technology/Automation:

Nancy L. Eaton and Julie B. Schwerin, "CDROM Optical Disc Technology in Libraries: Acceptance and Implementation."

Joe Santosuosso, "Access to Information in the Online Library.”

\section{READERS' SERVICES}

Integration of an Online Search Service into the ReFERENCE Department

Sandra E. Belanger

Rosemary Thorne

San Jose State University

In academic libraries, online searching services and reference departments often have to compete for a share of the same resources, i.e. budgets and personnel. This paper examines how San Jose State University Library solved the problems of shrinking budgets, space crunch and loss of trained searchers by integrating the online search service into the reference department. It describes the planning stages and interim organization necessary to effect the required changes. The paper also delineates how to simultaneously provide patron services and train online searchers, and includes discussions of recommended policy and procedure adjustments, and problems encountered. The conclusions analyze the use of this method in establishing a new online search service as well as its effect on academic reference service.

\section{EARS: The Photocopy Solution}

\section{Marilyn Borgendale}

\section{University of Maryland at Baltimore}

At the Health Sciences Library, EARS (Electronic Access to Reference Service) was developed in order to serve library patrons at remote sites. EARS is based on the library's electronic mail system with links to the online public catalog. It is menu-driven allowing users to request a computerized literature search; reference information; or a photocopy of a journal article. The paper discusses the impact the EARS photocopy service has had on the library staff and services. The existing staff has been able to undertake the added tasks of EARS. Response to the system has been positive from both patrons and library staff.

\section{Librarian Satisfaction with Computer Bibliographic Searching \\ Kevin Carey \\ University of Illinois at Chicago}

Computer searching is a reference service in academic libraries where good communication is essential. Successful computer searches are the result of an active exchange of information that combines subject expertise by the patron and search experience by the searcher. This paper examines the comments from interviews with twelve reference librarian searchers. It identifies their criteria for successful searching as a dynamic process between the searcher and the patron. The value of recognizing this process has implications for training programs and end-user instruction.

Psychological NeEds and Source Linkages in UNDERGRADUATE INFORMATION-SEEKING BEHAVIOR

\section{Kathleen Dunn \\ Loma Linda University}

This study contributes to the growing body of knowledge on the psychological factors involved in information search. Using undergraduates as subjects, psychological needs motivating their search for information in an academic context are identified. The categories of sources they use to satisfy their need for information are also identified. Significant relationships are empirically established between the motivating needs and categories of sources used.

\section{Reference Beyond (and Without) the Reference Desk \\ Barbara J. Ford \\ Trinity University}

Is the reference desk still the contact point where most library users can easily find the services, information and assistance they need? The author proposes that the reference desk as the center of reference service in academic libraries is an assumption that should be examined in light of new technologies and changes in the way people find and use information. An alternative or supplementary model is delineated by the author.

An Evaluation of Delivery Times and Costs of a Non-Library Document Delivery Service

\section{Douglas P. Hurd \\ Robert Molyneux \\ University of Virginia}

The number of non-library, commercial firms that provide document delivery services to libraries has been rising. It is difficult for librarians to determine what role these services will play in interli- 
brary loan activities because their performance has not been closely studied. In an effort to gain information about the delivery time and costs for private sector document delivery, a study was conducted at the University of Virginia. The study compares delivery times and invoiced costs for documents ordered from both conventional interlibrary loan sources and the UMI Article Clearinghouse.

\section{Building a Bridge: Articulation Programs FOR BIBLIOGRAPHIC INSTRUCTION}

\author{
Barbara E. Kemp \\ Mary M. Nofsinger \\ Alice M. Spitzer \\ Washington State University
}

This paper addresses educational articulation, with emphasis on the transition of students from high school to college. These students frequently lack library/research skills which is a major problem for bibliographic instruction librarians in academic libraries. Based on models of school/college cooperation, current cooperative projects involving academic libraries are discussed. The relevance of articulation efforts between high school and university libraries is emphasized.

\section{User Demand for Library SERVICES: \\ AN Undergraduate Library Model}

\section{Elaine McPheron}

State University of New York at Buffalo

Multiple linear regression analysis is used to test the hypothesis that demand for an undergraduate library, as measured by monograph circulation, is a function of these explanatory variables: size of collection, staff, enrollment, and library system; number of serial subscriptions and hours open; quality of students; and year of data. Results include a regression equation with t-statistics for the coefficients and analysis of variance, which together are used to explain the influence of each variable on demand and their combined success in explaining change in demand. Conclusions based on the data, problems with its interpretation, and suggested areas for further development are presented.

\section{The Library of Congress Optical Disk Print Pilot Project, Staff Evaluation}

\section{Victoria Ann Reich \\ Melissa Ann Betcher \\ Library of Congress}

This project was conducted April-May 1985 and involved 62 public service librarians. The evaluation goals were to involve the staff during the implementation of this new technology and to collect data on these objectives: to measure satisfaction with training, documentation, equipment, printing, and system reliability; to identify materials to be scanned; and general satisfaction. Terminal logs, a message phone, three questionnaires, and group interviews were used to collect data. Staff were generally satisfied with the system, with some interesting exceptions. Staff suggestions, once implemented, will ease the incorporation of the optical disk into the Library's environment.

\section{Reduction in Noise in Two Campus Libraries of a Major UNiversity \\ Sally S. Small \\ Maureen Strazdon \\ Pennsylvania State University}

Disruptive social behavior in two campus libraries precipitated increasing numbers of complaints from users who preferred a quiet orderly library environment. This presentation will discuss two library management strategies which attempted to alleviate the behavior problems using the different sets of resources available at the two campuses. The two strategies are described and contrasted with other tactics reported in the literature. Discussion centers on the role of the library as the campus academic/social center; the relationship between the number of users and the disruptive behavior; support of the local administration; and the obligation of the profession to provide a library environment conducive to study, reflection, and research for faculty and changing student populations.

\section{Robot at The ReFERence Desk?}

\section{Karen F. Smith}

\section{State University of New York at Buffalo}

Libraries seeking to enhance the productivity of reference librarians might consider ways to tap librarian expertise while the librarians themselves are off duty. This paper describes an experimental computer program designed to provide reference assistance for federal documents in a separate government documents department during hours when the regular staff members are not available. By making choices from a series of menus the patron conducts his or her own reference interview and is given a short list of appropriate reference books to consult. Difficulties to be overcome in the development of expert systems for use in reference work are discussed.

\section{Liberal Arts Colleges, Online Searching, and Economic Survival \\ Celia Wall Murray State University}

This idea brief proposes a cost savings measure applicable to small, private, liberal arts colleges which face difficult economic conditions. It argues that the use of expensive indexing and abstracting services in the libraries at these colleges is for two purposes: 1) teaching students how to use these services, and 2) searching of current literature, with the former being the majority use. This being the case, it is suggested that print subscriptions can be 


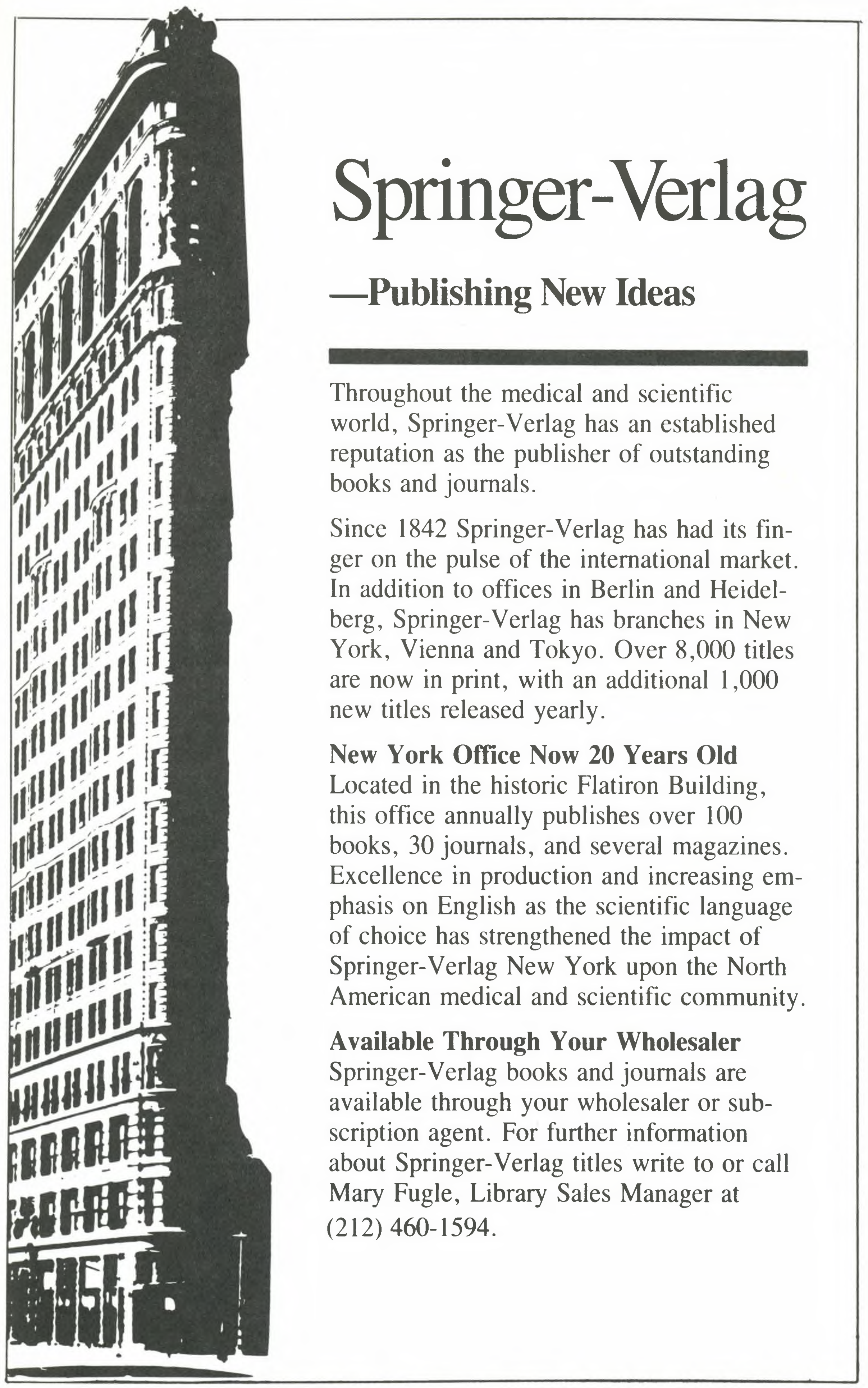


cancelled and back issues used to teach students how to use the services. Current literature searching, which can be expected to be light in the library of the small liberal arts college, can be accommodated by online searching. Implementation of the idea brief proposed here will result in a cost savings.

\section{SPECIAL COLLECTIONS}

The Clearinghouse for Curriculum

DeVElopment in Bioethics:

A Research Library Creates a

Database and Services to Respond to THE EMERGING NEED OF INTERDISCIPLINARY

Academic and Clinical Clientele

Judith Adams

Georgetown University

The Bioethics Library of the Kennedy Institute of Ethics, Georgetown University, has responded to the pressing need for new teaching programs in the interdisciplinary field of medical ethics by establishing a Clearinghouse for Curriculum Development and a Syllabus Exchange. Syllabi are solicited from academic, medical school, and high school faculty worldwide. A database, dubbed EMBRYO, is created using the M300 microcomputer, equipped with a Bernoulli Box for massstorage and manipulation, and dBase III software. The Clearinghouse allows the research library to assume a new role as communications facilitator for a network of scholars and clinical practitioners traditionally separated by disciplines and professional activities.

\section{InTEgrating Microforms with GOVERnMENT} Documents: A Third Alternative

\section{Edward Herman}

State University of New York at Buffalo

Two advantages of combining all government documents, regardless of format, and all microforms into one Documents and Microforms Department are discussed. 1) This approach enables librarians to more easily coordinate solutions to the difficulties users of each format face. 2) This approach enables librarians to provide services that emphasize "information," not "document retrieval." Also, librarians are urged to consider how well their existing collections are integrated into general library services before expanding into new services.

Another paper on Special Collections is:

Gretchen Lagana, "Beyond the Book: Collection Development and the Special Collections Librarian" (under Collection Development/Management).

\section{TECHNOLOGY/ AUTOMATION}

CD-ROM Optical Disk Technology in LIBRARIES: ACCEPTANCE AND IMPLEMENTATION

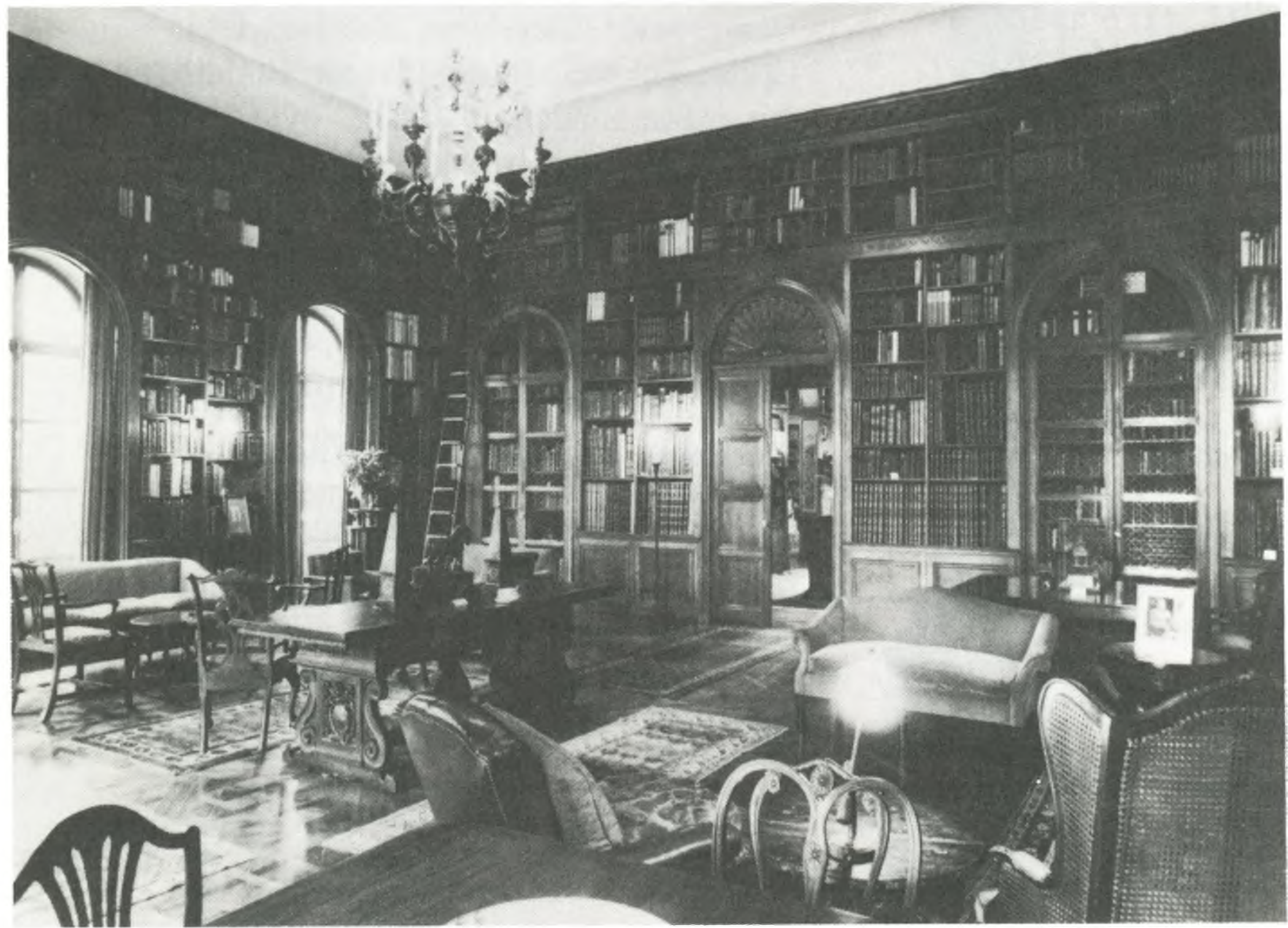

Reading room, John Work Garrett Library, Evergreen House, administered by the Libraries of the Johns Hopkins University. 
Nancy L. Eaton

University of Vermont

Julie B. Schwerin

Info Tech

A recent market survey forecast that libraries are believed by publishers to be likely for early adoption of optical disk-based information retrieval systems and that CD-ROM technology would dominate in this arena. This paper summarizes the state-of-the-art of CD-ROM technology and projects the likely applications of CD-ROM by the publishing industry. It explores the most likely ways in which librarians can make use of this information medium; and it suggests issues of facilities planning and workstation design pertinent to effective use.

The Use of an Electronic Conferencing System As a Middle and Upper Management Tool IN AN ACADEMIC LibraRY

\section{Virginia Gillham \\ University of Guelph}

CoSy, a user-friendly electronic conferencing system with adherents on three continents, is employed extensively at the University of Guelph as an internal administrative tool. Because most staff now instinctively resort first to the system as a method of communication, telephone ping-pong has been virtually eliminated, information transfer has been greatly improved and greatly increased, and meetings are now shorter, less frequent and more productive.

\section{A Populist Approach to Automation:}

Developing Local Systems in a

\section{Mainframe Context}

David F. Kohl

University of Illinois at Urbana

The increasingly mature automation environment of the 1980s provides new possibilities for dealing with large, shared mainframe systems such as LCS and WLN. By using microcomputers as an interface to the mainframe system, library patrons can be provided with customized access and services designed for local conditions and under local control. Such systems can be developed locally by use of off-the-shelf hardware and software and by the use of increasingly widespread automation expertise. Examples of such piggyback systems at the University of Illinois-Urbana are provided and the evolution of large, shared mainframe systems into providers of generic services with local microcomputer interfaces providing specialized local services is considered.

\section{Conservation, Preservation and Digitization}

Clifford A. Lynch

Edwin D. Brownrigg

University of California System

Considerable attention has been focused re-

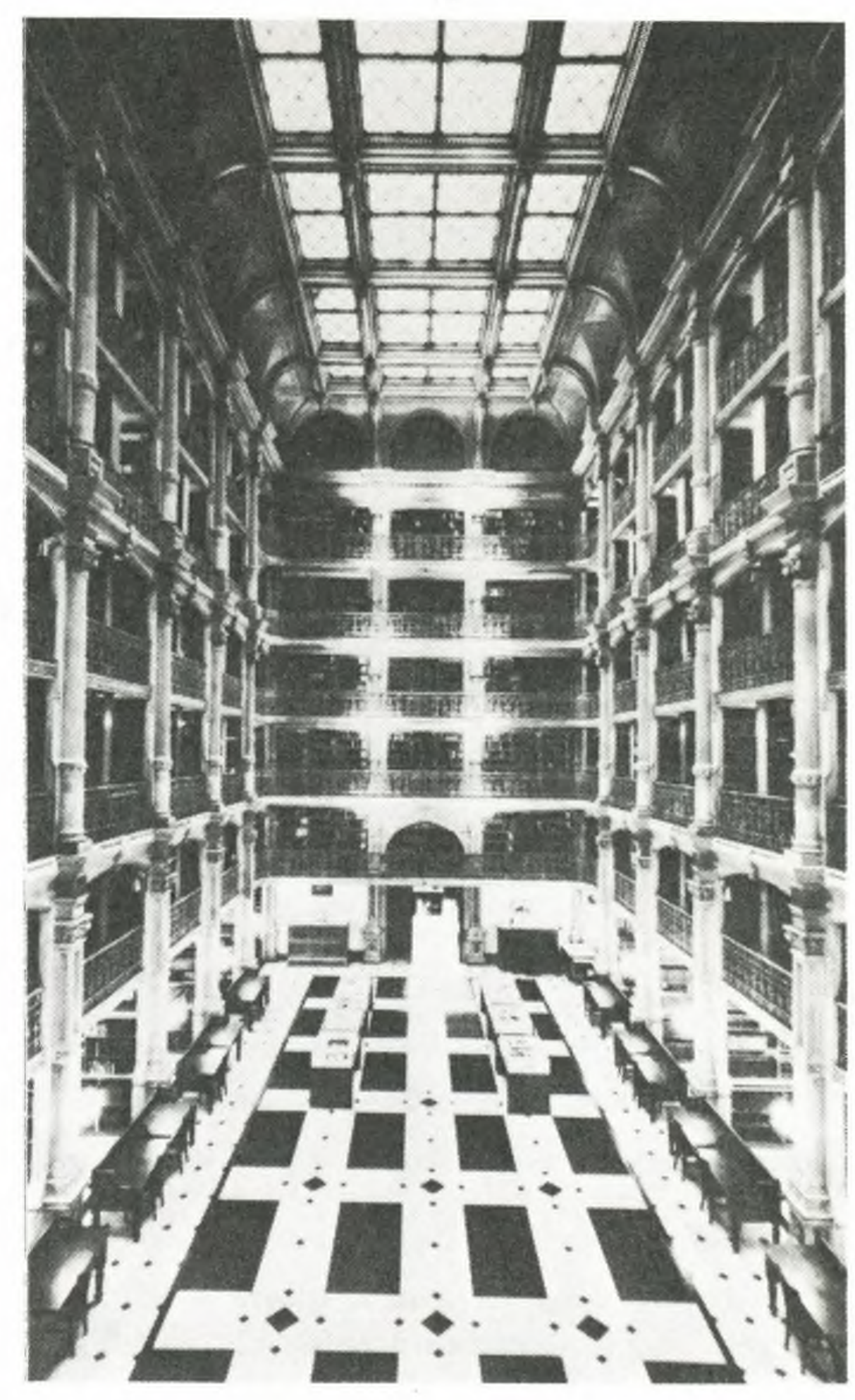

Interior of the Peabody Library, administered by Johns Hopkins University Libraries.

cently on the problems of conservation and preservation of library materials. Particularly daunting are the scale of the problems and the enormous ongoing investment that will be required to address them. Currently proposed approaches include extensive microfilming of material, deacidification, and other repaid measures. The authors argue that microfilming, one of the most commonly used methods for conservation and preservation, is inappropriate to the needs of libraries, which increasingly are offering online access to catalogs from home and office and eventually should provide access to the holdings themselves. A conservation and preservation program is an investment in the future, yet the end product of microfilming represents a deterioration in the usability of library holdings. The authors propose that digital technologies be used to accomplish simultaneously the aims of conservation and improved access to materials, and they review the various technologies that are necessary. Such an approach to conservation would form a natural extension to the current growth of electronic publishing, online catalogs, and online databases of journal abstracts. Furthermore, it would provide the greatest return for the massive investment that will be needed to save our deteriorating collections. 


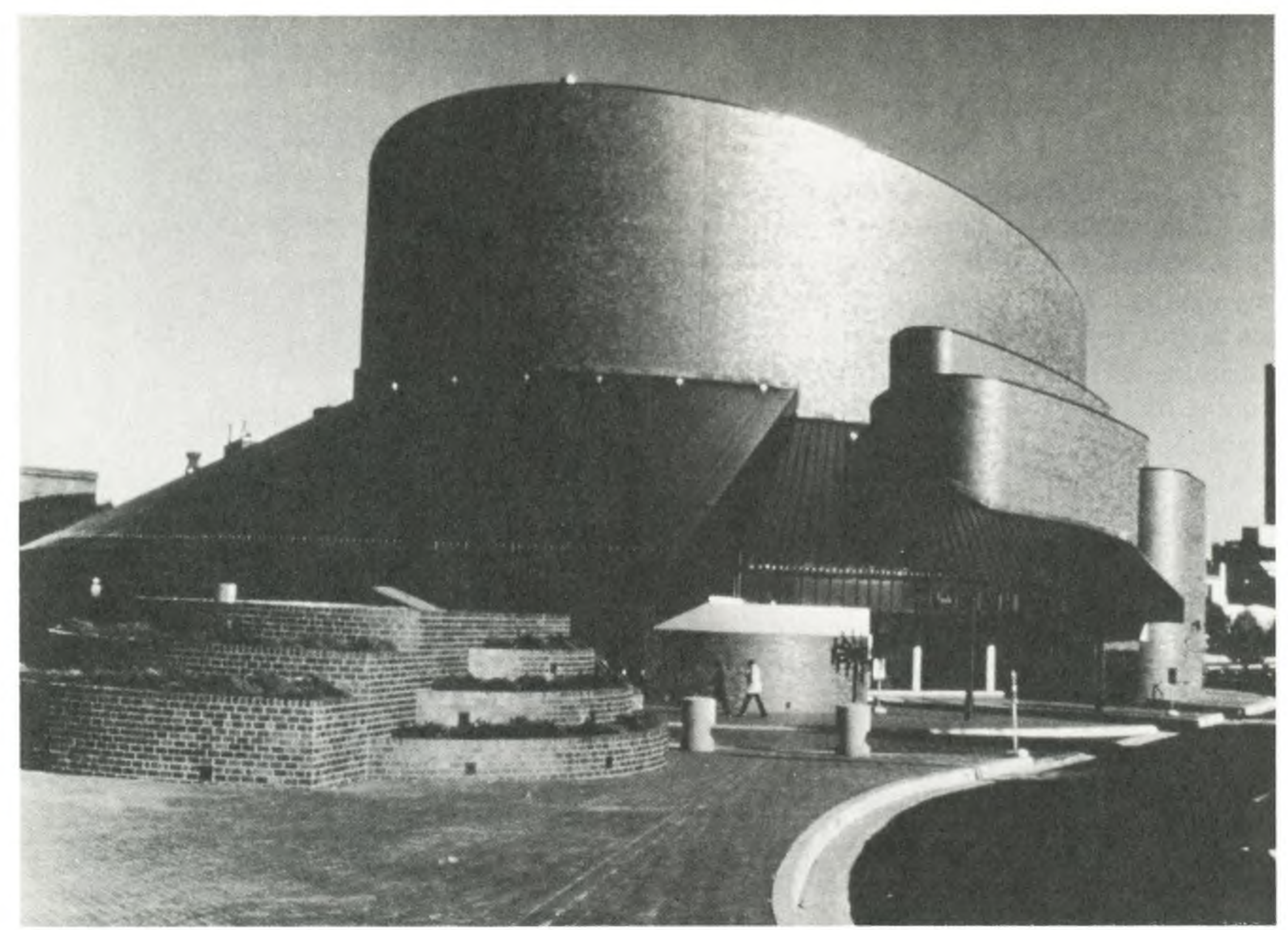

Joseph Meyerhoff Concert Hall, home of the Baltimore Symphony Orchestra.

Moving From a First Generation to a Second Generation Online Catalog Database

William E. Post Judith Sessions

California State University, Chico

California State University, Chico, is currently involved in a demonstration project to move from an operational first generation online catalog to an enhanced second generation online catalog. The purpose of this paper is to discuss the migration path chosen by CSU Chico for this transition, and particularly to illustrate how this transition is being made in a manner transparent to the users of the current first generation system. As always the database and maintaining its integrity is the crucial element in this transition. The methodology used at Chico to create, load and index a "clean" MARC database which has been synchronized with the current system's non-MARC database is discussed in detail.

\section{ACCESS TO INFORMATION IN THE ONLINE LibraRY \\ Joe Santosuosso CLSI}

The distribution of electronic information is bypassing libraries. Steps which academic libraries can take to continue to play a role in the dissemination of information in an electronic environment are described, including a change in orientation from information ownership to information access.
The Effect of Automation on the Rate of Change in Procedures

$$
\begin{gathered}
\text { Pat Weaver-Meyers } \\
\text { Nedria Santizo } \\
\text { University of Oklahoma }
\end{gathered}
$$

The continuing change in procedures that are part of new software development by vendors requires constant retraining of personnel and may not always be changes which your institution deems desirable. Realizing that the vendor's goals may not be consistent with your library's goals is basic to deciding whether to adopt, alter, defer or reject new capabilities. Some strategies are recommended to help librarians, in their increasing role as trainers and procedure manual developers, cope with the constant change which seems to accompany automation.

Eight other papers deal with Technology/Automation.

Under Academic/Research Librarianship:

Patricia Tegler and Constance Miller, "Online Searching and the Research Process."

Under Bibliographic Control/Cataloging:

David Gleim, Jaye Bausser, and Jinnie Y. Davis, "Error Detection in Bibliographic Records: Can the Computer Do It All?"

Ichiko Morita, "Quality Control of Online Catalogs: Automation vs. Human Control."

Under Bibliographic Instruction:

Linda Piele, Judith Pryor, and Harold Tuckett, "Teaching Microcomputer Literacy: New Roles for Academic Librarians." 
Judith G. Robinson and Julia R. Shaw, "The Effect of an End-User Training Program on an Online Search Service."

Under Collection Management/Development:

Colleen Cook, "A Model Interactive Automated Acquisitions System."

Norma Creaghe and Douglas A. Davis, "Hardcopy in Transition: The Plan for a Prototype Automated Storage and Retrieval Facility for Low Use Library Materials at California State University, Northridge."
Under Readers' Services:

Victoria Ann Reich and Melissa Ann Betcher, "The Library of Congress Optical Disk Print Pilot Project Staff Evaluation.”

\section{USER SURVEY}

See under Readers' Services:

Kathleen Dunn, "Psychological Needs and Source Linkages in Undergraduate InformationSeeking Behavior."

\section{ACRL Continuing Education Courses, Baltimore}

ACRL's CE courses are designed to provide librarians with knowledge and skills in areas of management, bibliographic instruction, library skills, technology update, and professional development. They are taught by library practitioners well known for their expertise in these topics. All registrants will receive a copy of the course syllabus.

The courses will be held at the Omni Hotel on Monday and Tuesday, April 7-8, immediately prior to the conference.

ACRL members receive a $30 \%$ discount on fees. If you register after March 7, you must include an additional $\$ 15$ late fee. A federal tax deduction is allowed for educational expenses (including registration fees, travel, meals, lodging) if courses are undertaken to maintain or improve professional skills (Treasury Reg. 1.162-5).

For registration information, contact Sandy Donnelly, ACRL/ALA, 50 E. Huron St., Chicago, IL 60611; (312) 944-6780.

A certificate of completion for each course will be issued. Every successful completion of 10 hours of continuing education is equal to one Continuing Education Unit (CEU). ACRL maintains a CEU record for each participant. All courses are approved for MLA re-certification credit.

\section{Public Service under Pressure: IMPROVING THE RESPONSE}

CE 113 deals with the problem endemic to public service-the difficult encounter between library staff and patron that results in an unsatisfactory outcome. Participants will examine ways of analyzing our knee-jerk responses under pressure and developing new responses that produce better results; discuss and practice techniques of handling pressure situations constructively by using examples from our day-to-day experiences (e.g., responding to the pushy patron, the VIP who refuses to accept a library policy, or the bizarre-appearing patron; dealing with a tough reference problem under adverse conditions, such as long lines, closing time; communicating with a hard-tounderstand patron; and much more). The limits of professional conduct will be explored with questions such as "When is it ok to get angry at the patron?" "Do I have to take abusive language from the patron?" Each participant will receive a handbook of specific effective responses to the types of situations dealt with in the workshop.

Note: This workshop does not deal with the mentally disturbed patron.

Instructors: Anne Lipow, Library Education Officer, and Suzanne Gallup, Head, Cooperative Services, University of California, Berkeley Library.

Date: Monday, April 7, 9:00 a.m.-4:30 p.m.

Fee: ACRL Members (30\% discount), $\$ 75$; nonmembers, $\$ 110$.

CEU Credit: . 7 .

Limited: to the first 100 registrants.

\section{Preparing for Technological Change}

CE 301 provides an opportunity for librarians to explore new roles, responsibilities, and services within the increasingly technological environment of libraries; to identify specific areas in which change can be anticipated and planned for; and to explore a variety of actions or strategies which can be used to address staff needs.

Instructors: Sheila Creth, Head of Personnel Services, University of Michigan Libraries, and Anne Lipow, Library Education Officer, University of California, Berkeley.

Date: Monday, April 7, and Tuesday, April 8, 9:00 a.m. $-5: 00$ p.m.

Fee: ACRL Members (30\% discount), \$150; non-members, $\$ 220$. 
CEU Credit: 1.4.

Limited: to the first 75 registrants.

\section{Written Communication in Libraries}

CE 504 is designed for librarians who must write on the job and who wish to do it more effectively and efficiently. Following an overview of general principles applicable to all written communication, the workshop considers several specific forms: letters and memos, reports, minutes of meetings, informational publications, press releases, and newsletters. It concludes with a discussion on methods used for physical preparation and reproduction.

Instructor: Richard D. Johnson, Director of Libraries, State University College, Oneonta, New York (formerly editor of College \& Research Libraries, co-editor of New Horizons for Academic Libraries and acting editor of Choice).

Date: Monday, April 7, 9:00 a.m.-5:00 p.m.

Fee: ACRL Members (30\% discount), $\$ 95$; nonmembers, $\$ 135$.

CEU Credit: .7.

Limited: to the first 35 registrants.

\section{LibraRIans AS SUPERVISORS}

CE 101 provides participants with skills necessary to become effective supervisors in library organizations. Helps participants develop awareness and understanding of current managerial concepts and practices. Specific objectives include: to increase self-awareness of behavior and managerial philosophy; to develop a greater appreciation of the supervisor's role and contribution to improving library performance; to gain an understanding of the skills required for effective supervision; and to examine individual approaches to supervision in response to the needs and demands of particular situations.

Instructor: Maureen Sullivan, Head of Personnel, Yale University Library.

Date: Monday, April 7, 9:00 a.m.-5:00 p.m.

Fee: ACRL members (30\% discount), $\$ 95$; nonmembers, $\$ 135$.

CEU Credit: .7.

Limited: to the first 30 registrants.

\section{Teaching Methods For the \\ BIBLIOGRAPHIC INSTRUCTION LIBRARIAN}

CE 202 provides an introduction to basic learning theory and alternate instructional methods used in library instruction. Participants will work on designing and modeling an instructional session.

Instructor: Cerise Oberman, Head, Walter Reference Library, University of Minnesota.

Date: Monday, April 7, and Tuesday, April 8, 9:00 a.m. $-5: 00$ p.m. (2-day course).

Fee: ACRL Members (30\% discount), \$190; non-members, $\$ 270$.

CEU Credit: 1.4 .

Limited: to the first 30 registrants.

\section{Survey Research Methods}

CE 503 seeks to acquaint participants with the methodology involved in conducting servey research, including: sampling techniques, questionnaire design, points to be included in proposals and written reports, and the critical evaluation of surveys found in the library literature. Participants are urged to bring their own study ideas to the workshop.

Instructor: Gary A. Golden, Acting Head of Reference, University of Illinois.

Date: Monday, April 7, and Tuesday, April 8, 9:00 a.m. $-5: 00$ p.m. (2 day course).

Fee: ACRL members, (30\% discount) $\$ 190$; non-members, $\$ 270$.

Limited: to the first 30 registrants.

\section{Establishing the College}

Bibliographic Instruction Program

CE 103 provides an overall review of managerial consideration essential in establishing the successful BI program. Program components examined will include political aspects, staff needs, budgetary support, and faculty and administration support.

Instructor: Dennis Robison, University Librarian, James Madison University.

Date: Tuesday, April 8, 8:30 a.m.-5:45 p.m.

Fee: ACRL Members (30\% discount), $\$ 95$; nonmembers, $\$ 135$.

CEU Credit: .8.

Limited: to the first 30 registrants.

\section{MANAging StUdent WorkERS IN ACADEMIC Libraries}

CE 107 seeks to clarify the nature of the student worker's role in academic libraries and the role of the supervisor of student workers; to identify management theories appropriate to student workers; to recognize the importance of selection, training, and supervision of student workers; to identify dilemmas or problems which occur in the management of student workers; and to become familiar with various ways in which policies and procedures can be communicated to student workers. The course is intended for librarians who have had at least one year of experience managing student workers or managing supervisors of student workers.

Instructor: Michael D. Kathman, Director of Libraries \& Media Services, St. John's University, and Jane Kathman, Assistant Professor and Chair of the Management Department, College of St. Benedict.

Date: Friday, April 8, 8:30 a.m.-5:00 p.m.

Fee: ACRL Members (30\% discount), $\$ 95$; nonmembers, $\$ 135$.

CEU Credit: .8.

Limited: to the first 30 registrants. 


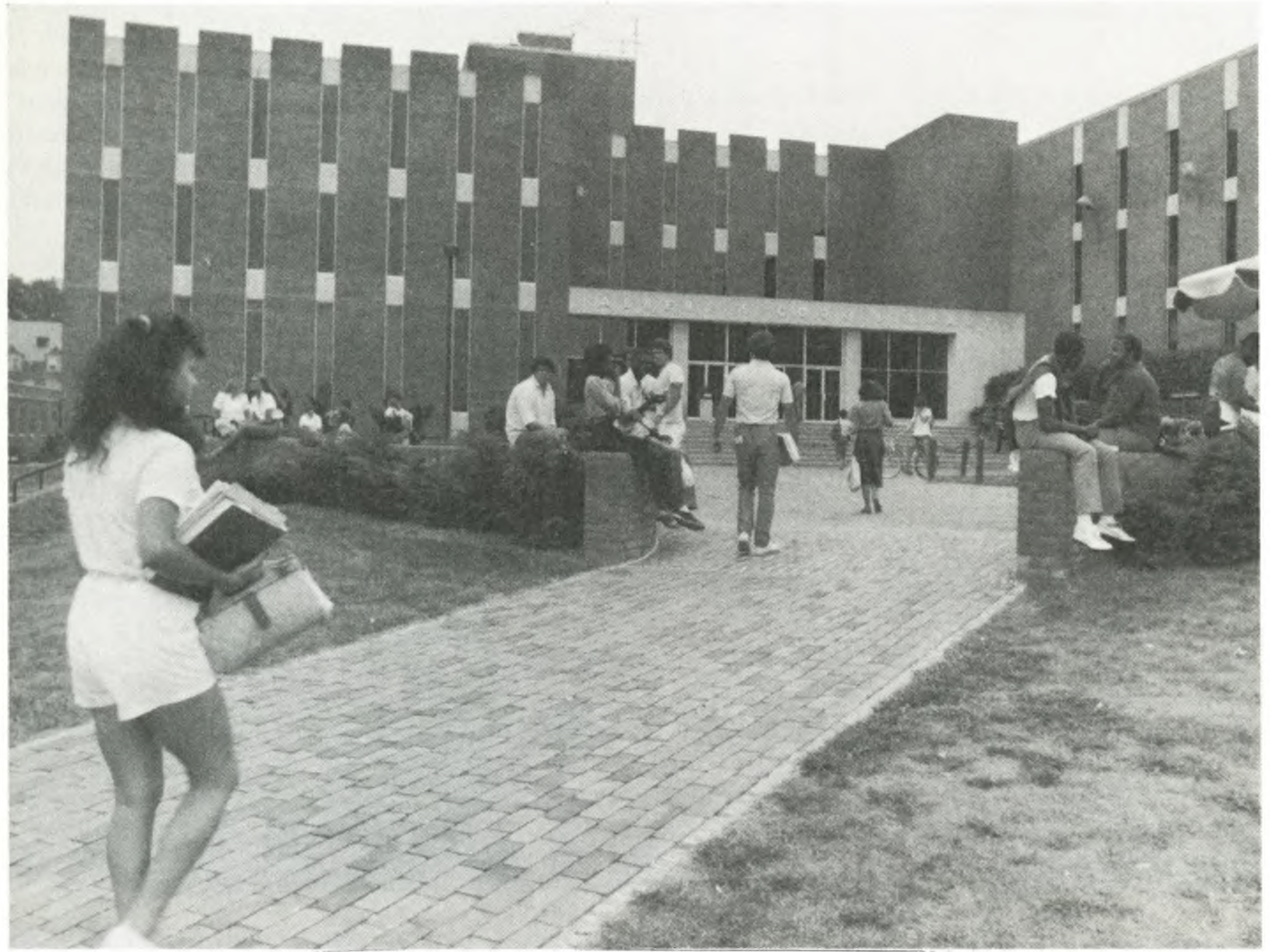

The Albert S. Cook Library, Towson State University.

An Introduction to Library Consulting Process and SkILls

CE 505 will provide experienced librarians with an overview of competencies, methods, roles and relationships that contribute to effective ccnsultation in academic libraries. The consultant may act as a trainer, fact-finder, researcher, diagnostician, conflict negotiator, or system designer. The course will examine the roles typically played by a consultant and the required skills, related problems, and expected results. The ingredients in effective consulting relationships will be examined, including: the consultant contract, orientation to the library, access to information, conceptual frameworks for analyzing information, working relationships with key staff, presenting results, and assessing the experience.

Instructor: Duane Webster, Deputy Executive Director, Association of Research Libraries, Office of Management Studies.

Date: Tuesday, April 8, 9:00 a.m.-5:00 p.m.

Fee: ACRL members (30\% discount), $\$ 95$; nonmembers, $\$ 135$.

CEU Credit: .7.

Limited: to the first 35 registrants.

Creative Approaches to Video for BIBLIOGRAPHIC INSTRUCTION

It is estimated that over 600 academic libraries have produced videotapes for bibliographic instruction. CE 206 examines uses of video, critical production issues, and a financial comparison of various media products. Many examples of library video products will be examined. In addition, creative problem-solving techniques will be applied to the process of developing a videotape project. A number of exercises designed to enhance creative potential will be conducted.

Instructor: Thomas McNally, Head, Circulation Department, Ohio State University.

Date: Tuesday, April 8, 9:00 a.m.-5:00 p.m.

Fee: ACRL members (30\% discount), \$95; nonmembers, $\$ 135$.

CEU Credit: .7.

Limited: to the first 40 registrants.

Operating and Marketing Fee-Based Services in ACADEMIC Libraries:

A Small Business Approach

CE 108a provides information to enable administrators and librarians from academic libraries and especially operating managers with the tools to analyze critically fee-based service operations. Participants are urged to bring any existing service brochures, price schedules, policy statements, and business plans with them to the program. These documents will be especially useful during the working portion of the program.

Instructor: Barbara Stump, Director, Regional 
Information \& Communication Exchange, Rice University Library.

Date: Tuesday, April 8, 9:00 a.m.-5:00 p.m.

Fee: ACRL members (30\% discount), $\$ 95$; nonmembers, $\$ 135$.

CEU Credit: .7.

Limited: to the first 50 registrants.

\section{Planning for Security in ACADEMIC Libraries}

CE 114 examines factors involved in designing a security program for an academic library building(s) from building use policy through implemen- tation. Participants will be asked to bring information with them concerning their own libraries. The course will consist of a variety of information sessions and activities leading to the development of indivilized security programs which address the safety of staff, patrons, and materials at all times.

Instructor: Thomas McNally, Head, Circulation Department, Ohio State University.

Date: Friday, April 7, 9:00 a.m.-5:00 p.m.

Fee: ACRL members (30\% discount), $\$ 95$; nonmembers, $\$ 135$.

CEU Credit: . 7.

Limited: to the first 40 registrants.

\title{
A diner's guide to Baltimore
}

\author{
By Bill Wilson \\ ACRL National Conference Publicity Committee
}

M encken reminded his readers that "Baltimore lay very near the immense protein factory of the Chesapeake Bay, and out of the bay it ate divinely.... There is a saying in Baltimore that crabs may be prepared in fifty ways and that all of them are good."

Seafood is what Baltimore's restaurants are best known for, but there is an amazing variety of cookeries (and price ranges) from which to choose, as the following very select list should suggest. Clustered by geographic settings is a personal selection of over 60 eateries within an eight-block radius of the Inner Harbor. This array omits many of Baltimore's finest establishments that are further afield. For those who wish to venture forth by auto or taxi, four free publications (available in or near conference hotels) contain much longer, annotated lists of the moderately priced to the very expensive restaurants: The Baltimore Chronicle, Baltimore Good Times (published by the Baltimore Office of Promotion and Tourism), Baltimore Scene Magazine, and City Paper.

In this list, $\$$ will stand for a meal that probably will cost less than $\$ 10$ per person; $\$ \$$, a meal in the range of \$10-\$20. Cocktails and wine are extra, of course. Also, figure in 5\% sales tax and 10-15\% for a tip. Unless otherwise noted, these restaurants accept several credit cards. Reservations are advised for lunch and dinner, unless it is stated that they are not accepted. If breakfast is available or featured, that is indicated; all charge less than $\$ 10$, and most are in the $\$ 2-\$ 4$ range. Bon Baltimore appetit!

${ }^{1}$ H.L. Mencken, A Choice of Days... New York: Knopf, 1980, pp. 40, 43.

\section{Conference hotels}

All of the conference hotels have coffee shops and dining rooms, although for the Holiday Inn and the Omni International Hotel their eateries will be renovated by April. The Baltimore Plaza Hotel, 110 South Eutaw Street between Lombard and Pratt, 962-0202, features its Cafe Atlantic with breakfast from 6-11 a.m.; lunch from 12-3 p.m. \$; and dinner from 5-10 p.m. $\$ \$$. The restaurant in Days Inn, at 100 Hopkins Place, 576-1000, is called Hopkins Place. It is open from 6 a.m. until 10 p.m., with a weekday brunch until 11 a.m.; lunch $\$$; and dinner $\$ \$$.

The Hyatt Regency Hotel on Light Street across from Harborplace, 528-1234, has a coffee shop with a cascading waterfall called Cascades, which Monday-Thursday is open 6:30 a.m. until only 3 p.m. for breakfast and lunch $\$$, but Friday and Saturday stays open for dinner $\$ \$$. The Trellis Garden is an elegant restaurant set amid lush greenery on the third floor of the Hyatt, which features seafood, beef, pasta, and salads for lunch starting at 11:30 a.m. and dinner from 6 p.m. $\$ \$$. Atop the Hyatt is a wonderful view of the city and harbor from Skylights Bar \& Restaurant, which serves a lunch of deli sandwiches and other lite fare from 11:30 a.m. to 2 p.m. $\$$ and a dinner of beef or seafood selections from 5 to $10: 30$ p.m. $\$ \$$.

\section{Harborplace}

The Light Street Pavilion has mostly restaurants, food stalls, and boutiques. Philip's Harborplace is the main attraction with three different places serving food on the Lower Level, 685-6600. 


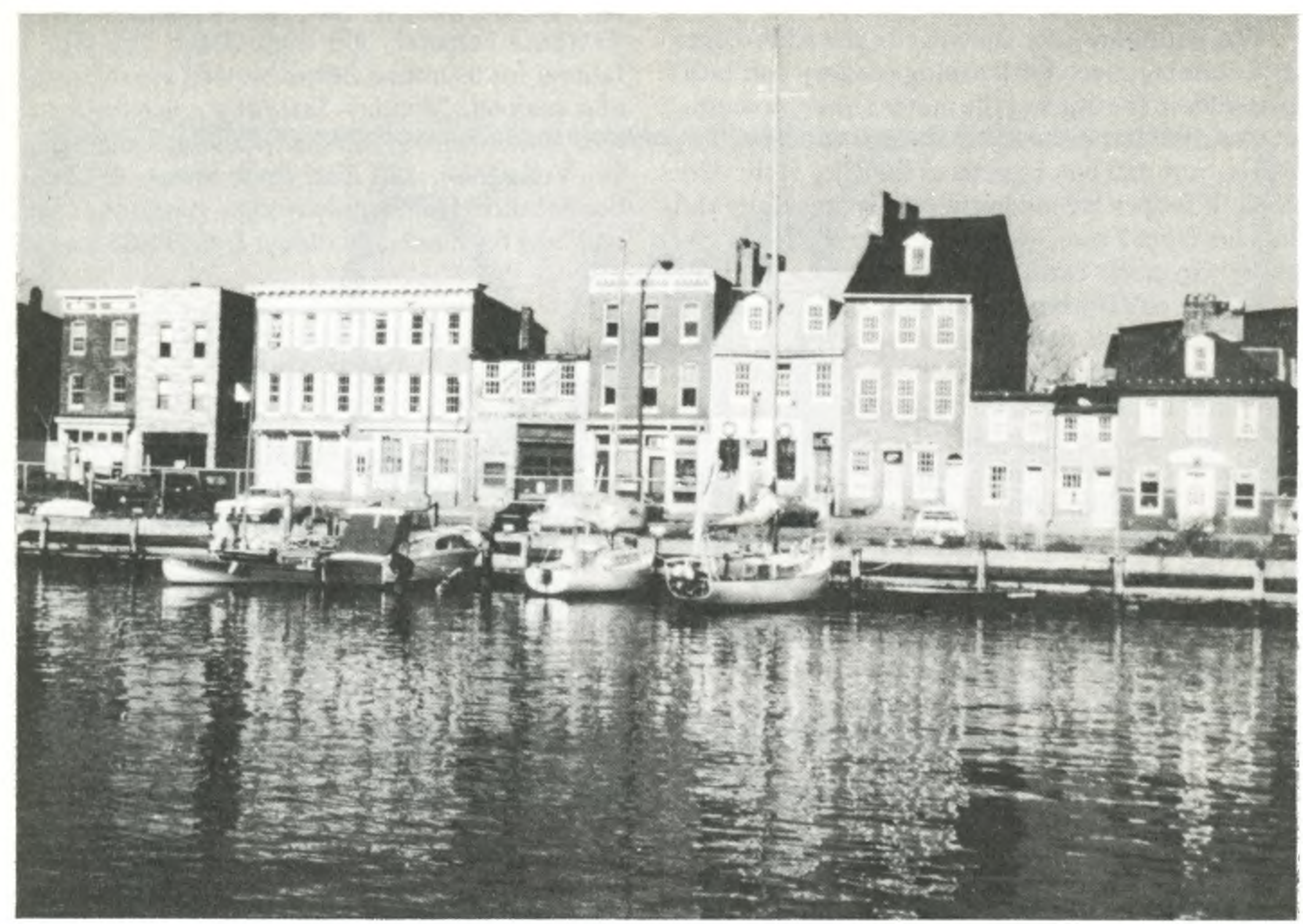

Fells Point, the original harbor of Baltimore.

These are offspring of an Ocean City (Maryland) seafood house, which has served "the finest in seafood since 1957." Open for lunch and dinner from 11 a.m. -11 p.m. $\$ \$$. No reservations, but the piano bar that runs from 1 p.m. to $1 \mathrm{a} . \mathrm{m}$. helps the wait pass quickly. Two favorite fast-food stalls on the Lower Level are Prime Potato, 547-0233, which offers baked potatoes with a variety of delicious toppings \$, and Ostrowksi's Polish Sausage, 5478088 , which sells homemade sausage on a stick, in a roll, or by the pound, $\$$.

On the Upper Level the American Cafe, 9628800 , is the leading attraction, partially because it offers the best view of the Inner Harbor. Open for lunch and dinner from 11 a.m. until either 2 or 3 a.m. \$\$. Soups, sandwiches, salads, and desserts are featured. Swensen's Ice Cream Factory is next door, 727-3500, and besides dessert treats, offers quiche, sandwiches, and salads $\$$. For the weightconscious the favorite spot on the Upper Level is Flying Fruit Fantasy, 547-8448, which serves fresh fruit cups and fruits and juices blended into natural fruit shakes $\$$.

\section{North and East of the Inner Harbor}

The Pratt Street Pavilion of Harborplace has several distinctive restaurants that are easily found. In this section I have listed ten places to eat that may not be so obvious. The Baltimore National Aquarium, which many conference goers will want to see during the reception on Thursday evening, features the Aquarium Cafe, 576-3839, open at 11 a.m. for lunch and snacks until 5 p.m., MondayThursday, and until 7 p.m. the other days $\$$. Seafood, salads, sandwiches, and desserts are served in a relaxed harbor-side setting.

The Chart House, 601 East Pratt Street, 5396616 , is the chain restaurant which specializes in steak, prime rib, and seafood, and which is housed in a converted warehouse. Mud pie is the one memorable dessert. No lunch or reservations. Cocktails from 3 p.m. and dinner from 4 until 10:30 p.m. $\$ \$$. Chez Fernand, formerly in Ellicot City before being wiped out by fire, 805 East Fayette Street, 7528030, features special gourmet dinners Monday and Friday but is open for lunch and dinner of more standard French fare every day, $\$ \$$. Ask to be seated in the garden room that overlooks Baltimore's famous Shot Tower and the redevelopment along the Fallsway.

Connolly's Seafood House, 701 East Pratt Street, $837-6400$, is a funky, down-to-earth crabcake eatery $\$$ on the waterfront in an old galvanized steel building, run by the same family for over 80 years, and a favorite with Mayor Schaefer. Closed Tuesday; no credit cards. L'Ecole, 19 S. Gay Street, 752-1446, has daily luncheon specials prepared and served by students of Baltimore's International Culinary Arts Institute $\$$. Monday-Thursday, 12 noon-1:45 p.m.; Friday buffet 11:30 a.m.-1:45 p.m. Reservations strongly advised. If you want the fare without the service, try their deli and bak- 
ery next door for take-outs, 752-1482.

The Baltimore City Schools run the Kid's Diner as a training place for learning cookery and business skills in the diner of the movie Diner, now situated at 400 East Saratoga at the corner of Holliday Street, just one block north of the City Hall, 3963583. It is open for modestly-priced breakfasts and lunches from 7 a.m. -3 p.m. \$. Hotcakes are a specialty. No credit cards; no reservations.

Uncle Lee's Harbor Restaurant, 44 South Street, 727-6666, is Baltimore's best known Szechuan Chinese restaurant and is located in a converted bank building. Lunch and dinner from 11:30 a.m., with many seafood specialties $\$ \$$. The Water Street Exchange, 110 Water Street (where the harbor used to end), 332-4060, offers light fare with emphasis on vegetables and enormous sandwiches in a Victorian setting for lunch and dinner from 11:30 a.m. $\$ \$$. Winchester's Restaurant \& Pub is next door at 102 Water Street, 576-8558. Lunch of croissants and salad or deli sandwiches starts at 11 a.m. $\$$. Through Thursday, Winchester's is open only until 9 p.m. for dinner, 11 p.m. on Friday, and 12 midnight on Saturday. Tempting unusual seafood combinations and steaks are served $\$ \$$. The Pub, which attracts a Yuppie crowd, stays open until 2 a.m. A favorite home-style restaurant of attorneys and bankers is Werner's Rstaurant, 231 E. Redwood Street, $752-3335$. Service is from 7 a.m. to 2:30 p.m. for plentiful breakfasts or lunch of hot platters, shrimp, or sandwiches $\$$. Since this Art Deco spot is popular and no reservations are taken, plan to lunch early or about 2 p.m. No credit cards.

\section{Little Italy}

Baltimore's most famous enclave of ethnic restaurants just beyond the Inner Harbor to the east offers at least nine choices. To get there you could ride the Baltimore Trolley on the Inner Harbor Route, which operates weekends and holidays between 10 a.m. and 11 p.m., and Friday evenings from 5 p.m. until 11 p.m. Fare is only 25 cents. At busy times reservations are in order for any of these restaurants. Caesar's Den, 223 S. High Street, $547-$ 0820, specializes in Roman, Neapolitan, and Sicilian cookery from 11:30 a.m. for lunch and dinner $\$ \$$. Capriccio, 845 Fawn Street, 685-2710, serves Northern Italian cuisine for lunch from 11:30 a.m. $-2: 30$ p.m. and for dinner from 5 p.m. $\$ \$$. Chiapparelli's Restaurant, 237 S. High Street, $837-$ 0309, specializes in veal, salads, and homemade pastas for lunch and dinner from 11 a.m. \$\$. Dalesio's, 829 Eastern Ave., 539-1965, has fresh seafood specials daily for dinner from 4 p.m., except Sunday when service starts at 2 p.m. Gnocchi is served instead of pasta \$\$. Da Mimmo, 217 S. High Street, 727-6876, features piano music nightly with its fine cuisine $\$ \$$. Opens for lunch at 11:30 p.m.

DeNitti's, 906 Trinity Street, 685-5601, specializes in award-winning pizza. Opens at 11 a.m. for lunch and dinner \$. Sabatino's, 901 Fawn Street, 727-9414, offers both Northern and Southern Ital- ian cuisine. Opens for lunch and dinner at noon $\$ \$$. Trattoria Petrucci, 300 High Street, 752-4515, is famous for its mussel dishes, as well as veal, pasta, and seafood. Monday-Saturday opens for lunch and dinner from 11:30 a.m.; Sunday from 2 p.m. $\$ \$$. Velleggia's, 829 East Pratt Street, 685-2620, boasts sauces from family recipes, pasta, veal, fish, and beef for lunch and dinner from 11:30 a.m. $\$ \$$

\section{North and West to Pratt Central}

On the streets that run north or south in the oneway traffic pattern in the heart of Baltimore (Charles, Liberty, and Park) and on cross streets are to be found numerous inviting restaurants from Chinese buffet to Spanish elegant. The Charles Street Route of the Baltimore Trolley will take you close to many of these restaurants for lunch, since it runs from 10 a.m. to 4 p.m., Monday through Friday. Brown's Coffee Bar in the back of Brown's Arcade, $326 \mathrm{~N}$. Charles, 752-2230, is open from 7 a.m. to 4 p.m., Monday-Friday, and 8 a.m. to 2 p.m. on Saturday. Several varieties of coffees and teas are always available, as well as pastries, waffles, and eggs for an inviting breakfast, or lunch of quiche and sandwiches \$. Burke's, 36 Light Street, $752-4189$, is a favorite hangout for lawyers and those who haunt the night; open $7 \mathrm{a} . \mathrm{m}$. to $2 \mathrm{a} . \mathrm{m}$. Very busy at lunch. Noted for hearty fare such as burgers, and for crabcakes and good desserts after an evening's entertainment $\$$.

The China Doll Restaurant, 406 Park Avenue, $539-7892$, serves steamed fish as a specialty $\$$. No credit cards. The Chinese Gourmet, 323 Park Avenue, 685-2868, features a $\$ 4.75$ Chinese buffet daily, for which reservations are suggested. Lexington Market has been in business for over 200 years at Lexington and Paca Streets and provides an incredible array of food stalls from which to select a meal. Most famous is Faidley Seafood, 7274898 , which offers a seafood cafeteria and a large raw bar, from 7:30 a.m. to 6 p.m., Monday through Saturday $\$$. The Lighthouse, 10 Park Avenue, 727-3814, serves breakfast from 7 a.m., Monday through Saturday, and a good selection of seafood and steak for lunch $\$$ and dinner $\$ \$$.

Louie's The Bookstore Cafe, 518 N. Charles Street, 962-1224, specializes in seafood, light fare, and yummy desserts and sometimes provides chamber music performed by students from the Peabody Conservatory. A fine selection of reading material is always on sale. Marconi's, 106 W. Saratoga Street, 752-9286, is a favorite of old Baltimoreans, including Pratt staffers, for continental cuisine. Tuesday through Saturday lunch is served noon to $3: 30$ p.m. and dinner from 5 to 8 p.m. $\$ \$$. No reservations, so a wait in the hall is likely. Marshall's, 12 S. Calvert Street, 837-2233, serves a lunch of ribs, steaks, seafood, or sandwiches from 11:30 a.m. until 3 p.m. $\$$, but no dinner. Bar remains open until 2 a.m. 


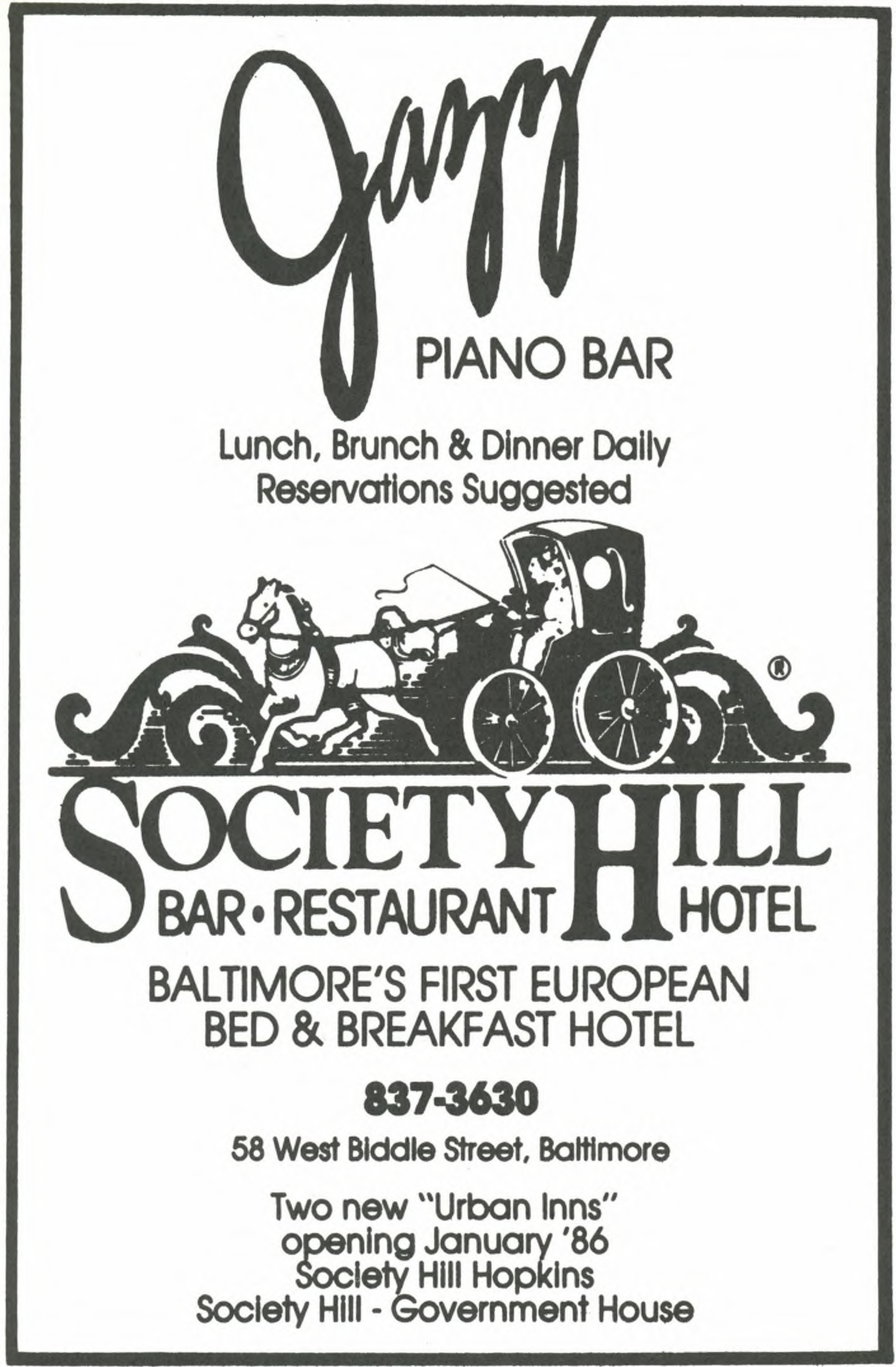




\section{Announcing}

\section{Index to Scientific Book Contents ${ }^{\mathrm{TW}}$ $\left(\mathbf{I S B C}^{\mathrm{nI}}\right)$}

Finally!...

- chapter-level access to multi-authored scientific books

- access by author

- access by editor

- access by chapter subject

- access by book subject

- access by author's organizational affiliation

- meets your need for current awareness, bibliographic verification, retrospective searching (published quarterly and cumulated annually)

\section{Write or call for your FREE sample issue.}

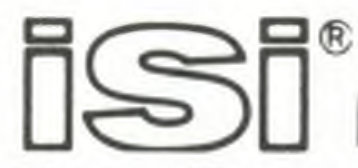

Attn: Customer Services Department

3501 Market St., Philadelphia, PA 19104 U.S.A.

Toll-free: (800) 523-1850, ext. 1371

In Pennsylvania and outside U.S.A.: (215) 386-0100, ext. 1371

Cable: SCINFO, Telex 84-5305

European Office:

132 High St., Uxbridge, Middlesex UB8 1DP, United Kingdom

Phone: 44-895-70016, Telex: 933693 UKISI 
Midtown Yacht Club is a delightful pub in Mount Vernon near the Peabody and the Walters at 15 E. Centre Street, 837-1300, which offers soups and Cajun-inspired seafood cooking \$ every day from 11:30 a.m. until 2 a.m. The Orchid, 419 N. Charles Street (next to where Upton Sinclair lived in Baltimore), 837-0080, succeeds in blending French entrees with Chinese ingredients and sauces $\$ \$$. Open every day for lunch from 11:30 a.m. to 3 p.m. and dinner from 5:30 until 11 p.m. Pacifica (in Brown's Arcade), 326 N. Charles Street, 727-8264, is Baltimore's original mesquite charcoal grill restaurant, which offers fish, meats, and hamburgers, plus veal chop, game, and raw bar $\$ \$$. Peerce's Downtown, 225 N. Liberty Street, 727-0910, specializes in Louisiana-style gourmet cuisine for lunch and dinner $\$ \$$ from 11:30 a.m. on weekdays, from 5 p.m. on Saturday, and from 4 p.m. on Sunday.

Shogun, 316 N. Charles Street, 962-1130, is a feast for the eyes as well as the palate. It serves traditional Japanese dishes such as sushi, shasimi, tempura, kushiyaki, and teriyaki \$\$, from 11:30 Tuesday through Friday, from 5 p.m. on Saturday, and 4 p.m. on Sunday. Sony's, 324 Park Avenue, 539-2466, is a Phillipine restaurant that offers delightfully different dishes for dinner from 5:30 to $9: 30$ p.m. daily $\$ \$$. Some of their treats are available for lunch in the Light Street Pavilion of Harborplace on the Upper Level \$. Tio Pepe's is probably the best-known expensive restaurant in downtown Baltimore, located in the Hispanicstyle cellar of a large townhouse at $10 \mathrm{E}$. Franklin Street, 539-4675. Tio Pepe's is famous for its authentic Spanish cuisine from mussels to game birds. To end your meal make a delectable choice from the pastry cart. Lunch Monday-Friday from 11:30 a.m. to 2:30 p.m.; dinner Monday-Saturday from 5 p.m. and Sunday from 4 p.m. Reservations are essential $\$ \$$.

If you are a reader of Gentleman's Quarterly and dress accordingly, you will like Tug's, 222 St. Paul Place, 244-7300, which serves seafood and steaks $\$ \$$ for lunch from $11: 30$ a.m. to $2: 30$ p.m. Monday-Friday and for dinner from 5:30 to 10:30 p.m. Monday-Saturday. A favorite spot to lunch and shop for handerafted gift items or baked goods is The Woman's Industrial Exchange, $333 \mathrm{~N}$. Charles Street, 685-4388. This is an old-fashioned tearoom that dates from 1882. Breakfast is served from 7 to 11 a.m. and lunch from then until 2:30 p.m. \$. No credit cards.

\section{West toward the B\&O Railroad Museum}

Off Lombard Street, which runs east to west, and off Pratt Street, which runs west to east, and nearby, are several inviting restaurants. A favorite with politicians, including Senator Sarbanes, and famous for crabcakes is the Ambassador House Restaurant, 400 W. Lombard Street, 752-1819 \$. The dining room is open from 9 a.m. to 10 p.m. and accepts credit cards; an adjoining grill facing Eutaw Street is open 24 hours a day and discourages credit cards. Billy's Restaurant \& Lounge offers lunch and late nite fare from 11:30 a.m. to 2 a.m., Monday through Friday, on the first level of the Convention Center Mall, at Charles and Pratt Streets, $244-0044 \$$. No reservations. Saturday happy hour from 8 p.m. to 2 a.m. Right next door is Gus Leanos' Restaurant Delicatessen, 539-1425, open from 7 a.m. for breakfast until 6 p.m. $\$$. On the second level of the Convention center mall is Cinnabar, which serves Szechuan and Hunan cuisine from 11 a.m. until 10:30 p.m. $\$$. A buffet lunch at $\$ 5.45$ is popular. A pioneer in a restored Victorian building in the construction zone around the Convention Center is P.J. Crickett's, 206 W. Pratt Street, 244-8900, which ought to win an award for sticking it out through two thin years while streets and sidewalks were torn up. Lunch from 11:30 a.m. and dinner are served, featuring barbecued baby ribs, soups, salads, full-course meals, and a raw bar $\$$.

If you are looking for a family atmosphere, try the Friendly Ice Cream Shop (part of a chain), 100 E. Pratt Street, 752-5320, for breakfast from 7 a.m. or lunch $\$$ of salad, sandwich or soup. Their ice cream concoctions are good any time of the day. Open Monday-Friday until 6 p.m. and until 5 p.m. on the weekend. No credit cards. Jake's Delicatesssen Carry-Out at 114 E. Lombard Street, $385-0010$, might hit the spot on a nice day. Lunch $\$$ may be eaten either inside or outside on a plaza surrounding one of the several nearby office blocks. A recent welcome addition nestled between Ridgely's Delight and Barre Circle is La Parisienne French Pantry \& Bistro, $925 \mathrm{~W}$. Barre Street, just off Washington Boulevard, 332-1065. A fine place for a continental breakfast from 7 a.m., MondayFriday, 6:30 p.m. on Saturday, or 2 p.m. on Sunday. No alcohol or credit cards. Popular with students from the professional schools of the University of Maryland, as well as neighbors, is the Penn Restaurant, 663 W. Pratt Street, 752-3606. Filling breakfasts are served as early as 6 a.m. Inexpensive meals with a dash of Greek flavor are served until 8 p.m. \$. No credit cards. Also popular with students and staff of the University is the Galloping Gourmet Cafe, 11 South Paca Street, across from University Square, 625-1441. Morning fare is served from 7:30 a.m. and lunch, either in or carry out, until 3 p.m. $\$$.

\section{South Baltimore}

Directly south of the Inner Harbor is the Federal Hill area, which has been largely gentrified, but to the west and south of the Hill is a large neighborhood of working-class people. Several neighborhood restaurants are inviting to tourists also. AlleyOop's, 1043 Marshall Street, 962-8988, specializes in seafood and pasta $\$$. This place is tucked in a side 
street just north of the Cross Street Market and is open for lunch and dinner from 11 a.m. until 10 p.m., Monday-Thursday, and until 2 a.m. Friday-Sunday. The Cross Street Market itself, between Light and S. Charles Streets, gives visitors a taste of the real Baltimore at places such as Nick's for raw bar and other seafood or Steve's Lunch, a long, old-fashioned, stand-up lunch counter, both \$. Monday-Thursday the Market is open from 7 a.m. to 6 p.m. and on Friday and Saturday from 6 a.m., for those joggers who want something after a run. Also, just across from the Market is Sisson's, 36 E. Cross Street, 539-2093, which is a bar with beer on tap and crowded with convivial people who like their music loud. From 5 p.m. dinner $\$$, featuring Cajun cuisine, mussels, and oysters, is served.

Regi's, 1002 Light Street, 539-7344, is a tonier place in this eclectic neighborhood, and serves lunch, dinner, and especially brunch $\$ \$$. Daily specials, original sandwiches, and chili are popular. The Rusty Scupper, 402 Key Highway at the Inner
Harbor Marina, 727-3678, is part of a chain. This is an ideal spot to view crafts plying the Inner Harbor. Open daily from 11:30 a.m. to 10 p.m. and Sunday from 1 to 9 p.m., seafood is featured $\$ \$$. The Soup Kitchen, 1026 S. Charles Street, 7523810 , specializes in soups, salads, light fare, and wonderful desserts, as does its sister establishment in the Light Street Pavilion of Harborplace $\$ \$$. If you want to see a real soup kitchen for the many homeless of Baltimore, the Catholic Church runs one on Franklin Street, practically at the front door of Pratt Central. Szechuan, 1125 S. Charles Street, $752-8409$, is considered by many to be the best Chinese restaurant in Baltimore, serving Peking-style as well as Szechuan dishes of beef, pork, poultry, and seafood-some spicy hot and some mild $\$ \$$. Bring your own alcoholic beverages for lunch Monday-Friday from 11:30 a.m. to 3 p.m., or dinner Monday-Friday from 5 to 10 p.m. and Saturday 4 to $10: 30$ p.m. Be prepared for a wait if you go on Friday or Saturday night.

\section{Transportation}

T.V. Travel is the official travel agency for the Conference. Any attendee purchasing tickets through T.V. Travel and travelling round-trip on Eastern Airlines may save $40 \%$ off the full coach airfare. Reservations for these Eastern tickets must be made and tickets purchased at least seven days prior to departure.

T.V. Travel will also be able to offer discounts on American Airlines. All attendees travelling round-trip to the conference on American Airlines may save $40 \%$ off the coach airfares by making reservations at least 30 days prior to departure. For reservations made 7-29 days prior to departure, a $35 \%$ discount is being offered.

Any attendee booking 30 days in advance whose stay includes a Saturday night may take advantage of further discounts; just ask the reservationist to check for the lowest available airfare.

In addition to the special airfares, all conference attendees purchasing tickets through T.V. Travel will receive $\$ 150,000$ worth of complimentary travel accident insurance. To make reservations, call (800) 543-9089; in Ohio (800) 762-0712. Use the identifier: "ACRL."

The newly-expanded Baltimore-Washington International Airport is located 10 miles from center city. Taxis and buses provide easy access to downtown.

Baltimore's recently refurbished Pennsylvania Station is located a five-minute taxi ride from center-city hotels. Amtrak service provides rapid transportation along the entire Northeast corridor, including Montreal, Boston, New York, Philadelphia, Washington, and points south, with indirect routes from Chicago, New Orleans, and the West Coast.

Baltimore is conveniently linked by the Interstate system in four directions from the Beltway (I$695)$ that surrounds the city: I-70 to Frederick and the west, I-83 to Harrisburg and the north, and I95 northeast to New Jersey and southwest to Washington. Trailways (close to the Convention Center) and Greyhound both serve Baltimore. For detailed sightseeing information about Baltimore and environs consult the ten-page section in the $A A A$ Guide. Within Baltimore, tourists are well-served by the new Metro, public transit buses, and taxis. The conference hotels are all within walking distance of the Convention Center.

\section{Placement Service}

A Placement Service will be available for use by any conference participant to list job openings or to register as a job applicant for entry-level through upper management-level positions. The Placement Service will be located in the Baltimore Convention Center. Interview tables and space will be available.

If you wish to be sent forms to use the Placement Service at the conference, send your name and address to: Energies for Transition, Placement Service, ACRL, 50 East Huron Street, Chicago, IL 60611 .

Specify if you want an employer or employee form. 


\section{OMNI INTERNATIONAL}

welcomes the membership of $A C R L$ to Baltimore for its 4th National Conference!

We are holding 600 rooms for your use.

Omni International is only two blocks from the Baltimore Convention Center.

Please mark Omni International as your first housing choice!

Omni International

101 W. Fayette Street

Baltimore, MD 19110

(301) $752-1100$

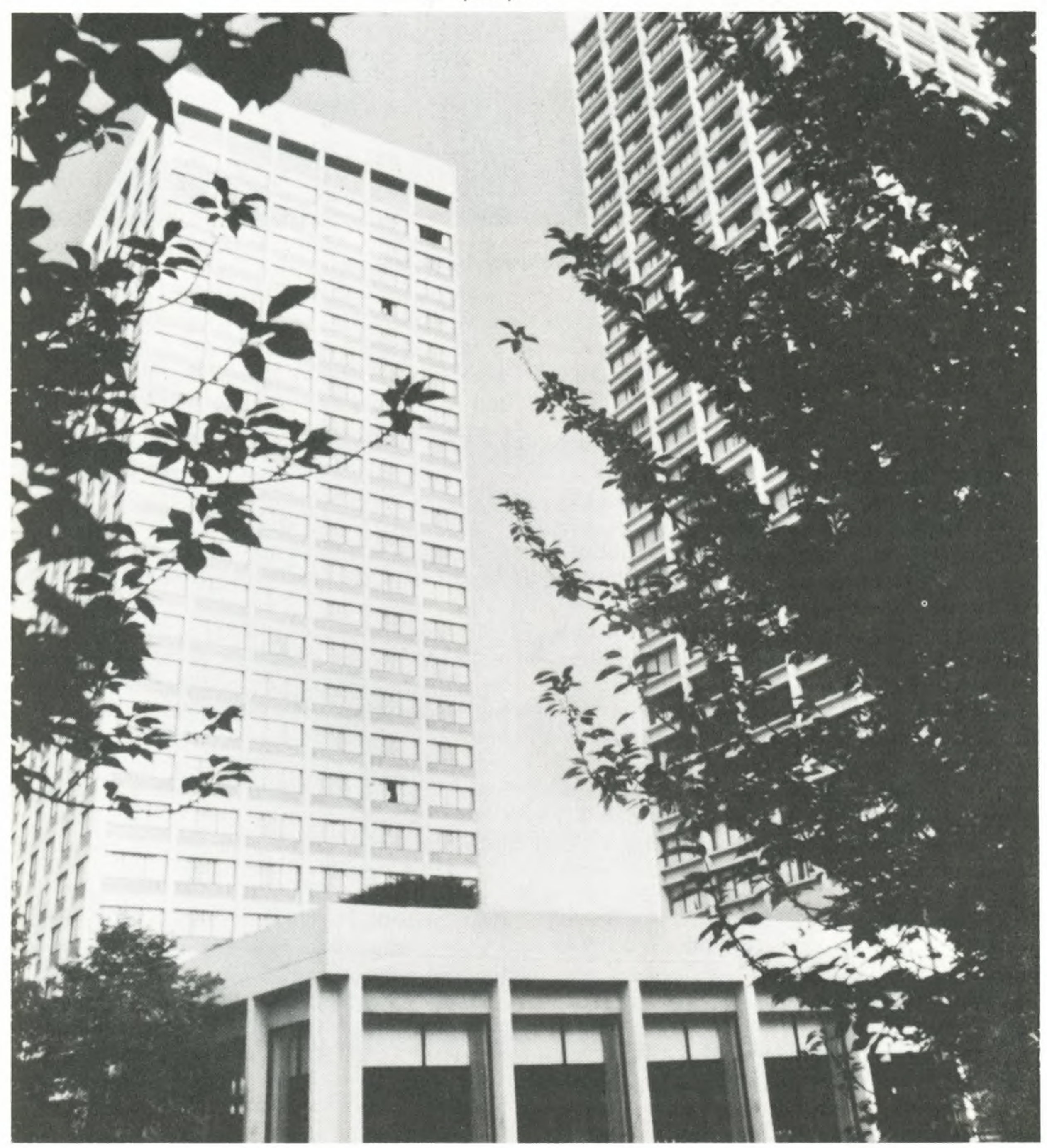




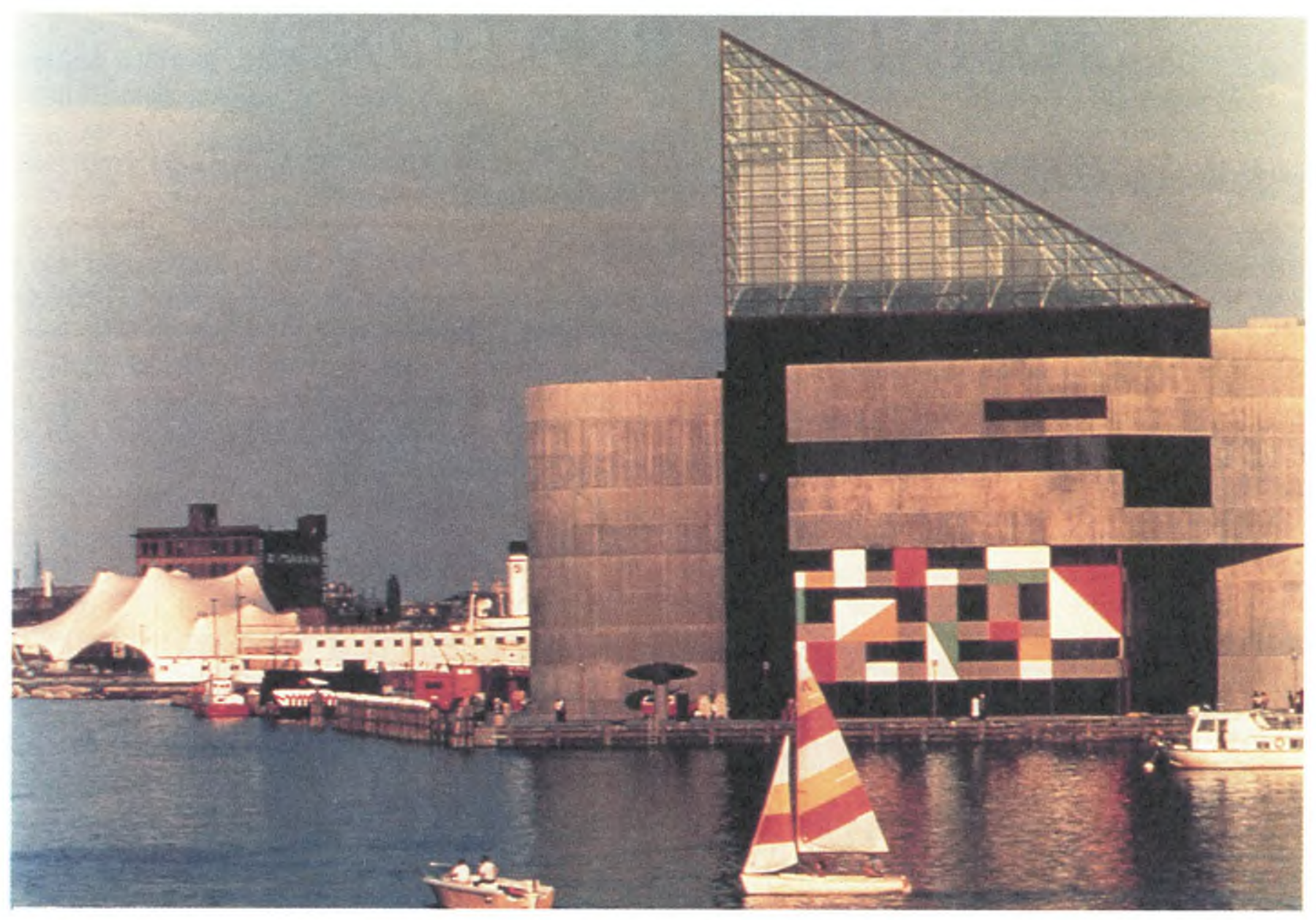

Baltimore's National Aquarium.

\section{Registration}

Registration will be at the Baltimore Convention Center and will open at 8:00 a.m. on April 9, 1986. All meetings, with the exception of the Continuing Education courses at the Omni Hotel, will be at the Baltimore Convention Center.

Full-conference participants can save $\$ 20$ by registering by March 1, 1986. Fees for the full conference postmarked by March 1 are as follows: for members of both ALA and ACRL, $\$ 90$; for members of ALA and not ACRL, $\$ 115$; for members of ACRL chapters who are not members of ALA, $\$ 125$; for non-members of ALA, $\$ 130$; for ALA student members, $\$ 30$; for non-librarian guests, $\$ 30$.

All full-conference registration fees postmarked after March 1 are $\$ 20$ in addition to the appropriate cost given above.

Daily registration will only be available on-site in Baltimore. Daily costs are as follows: for members of both ALA and ACRL, \$40; for members of ALA and not ACRL, $\$ 45$; for members of ACRL chapters who are not members of ALA, $\$ 50$; for non-members of ALA, $\$ 55$; for ALA student members, $\$ 20$; for non-librarian guests, $\$ 20$.

All personal and institutional members of ACRL in the United States and Canada should have received a registration packet by now. Non-members and ACRL members in other countries may request registration materials by mailing the form on page 58 .

\section{Hotels}

Six official conference hotels within a few blocks of the Convention Center have been confirmed for the Conference. Rates at the hotels range from $\$ 46-\$ 89$ for a single and from $\$ 66-\$ 99$ for a double. A $11 \%$ city/state hotel tax must be added to all prices. Reservations for rooms at the official conference hotels are being handled by the Baltimore Convention Bureau. Use the form in the preregistration packet to reserve a room.

The six official conference hotels are:

Days Inn: Opened in September 1984, the Days Inn offers moderately priced rooms, dining facilities and is directly across the street from the Convention Center.

Holiday Inn: A major renovation to be completed this month will add an indoor pool and remodeled rooms and restaurant.

Howard House: An older hotel in downtown Baltimore, nicely restored with moderately priced accomodations.

Hyatt: Linked by an overhead pedestrian walk- 
way to the Convention Center and Harborplace, the Hyatt is a lovely 14-story hotel with an atrium, restaurants, tennis courts and a jogging track.

Omni: Also connected to the Convention Center and Harborplace by overhead walkways, the Omni has been completely renovated and is a firstclass hotel.

Plaza: Just opened in 1985, the Plaza offers an indoor pool, saunas and exercise facilities as well as comfortable rooms and a restaurant.

Veteran conference goers know that there are many unplanned ways to enhance the experience of a conference by sharing informal moments with colleagues who are staying at the same hotel. However, there may be reasons why some persons do not wish to register at a conference hotel. Some alternatives are listed below. Those librarians traveling by auto and/or bringing families on spring vacations may wish to reserve room(s) at one of several family motels, most of which are near the Beltway that surrounds Baltimore. If so, call: Best Western (4 in the area), (301) 467-2693; Holiday Inn (10 besides the Conference hotel on Lombard Street), (800) 465-4329; Quality Inns (4 in the area), (800), 228-5151; Ramada (1 in the area), (800) 228-2828; or Shoney's Motor Inn (1 brand new and just off the Beltway, off I-95 on the southwestern side of downtown), (301) 646-1700.

Within a mile or two of the Convention Center, there are three new, elegant, small hotels from which to choose. The Admiral Fell Inn is on Baltimore's waterfront at $888 \mathrm{~S}$. Broadway in Fells
Point, (301) 522-7377. Its 37 rooms range from $\$ 80-\$ 125$ for a single and $\$ 90-\$ 135$ for a double. Rates include continental breakfast in the library near the lobby, shoe shine, morning paper, and transportation to the Convention Center.

The Shirley House, "Your Home Away from Home," is in a restored Victorian building off Mount Vernon Place at 205 W. Madison St., (301) $728-6550$. Seventeen rooms are priced from $\$ 50$ for a single to $\$ 110$ for a suite. Add $\$ 15$ for an additional occupant. Most rooms include an equipped kitchenette, but a continental breakfast is served in the lobby. A block away is a busline downtown, and transportation is provided to the Convention Center.

Society Hill Hotel is a stunning Edwardian townhouse with 15 guest rooms across the street from the Meyerhoff Symphony Hall at 58 W. Biddle Street, (301) 837-3630. Rooms are priced according to size of bed-not the number of room occupants. $\$ 65$ for single, $\$ 75$ for queen, $\$ 80$ for two double beds, and $\$ 90$ for king. Price includes free potpourri in bath, continental breakfast in the room, off-street parking, and private-line, free, local telephone service. Society Hill Hotel has a very snug bar/restaurant in the basement.

Although Baltimore is London-like in its neighborhoods, the bed and breakfast phenomenon has yet to really hit. However, just south of the Inner Harbor, with some rooms overlooking it, is Eagle's Mere Bed \& Breakfast at 102 E. Montgomery Street, (301) 332-1618. Four rooms can accommo-

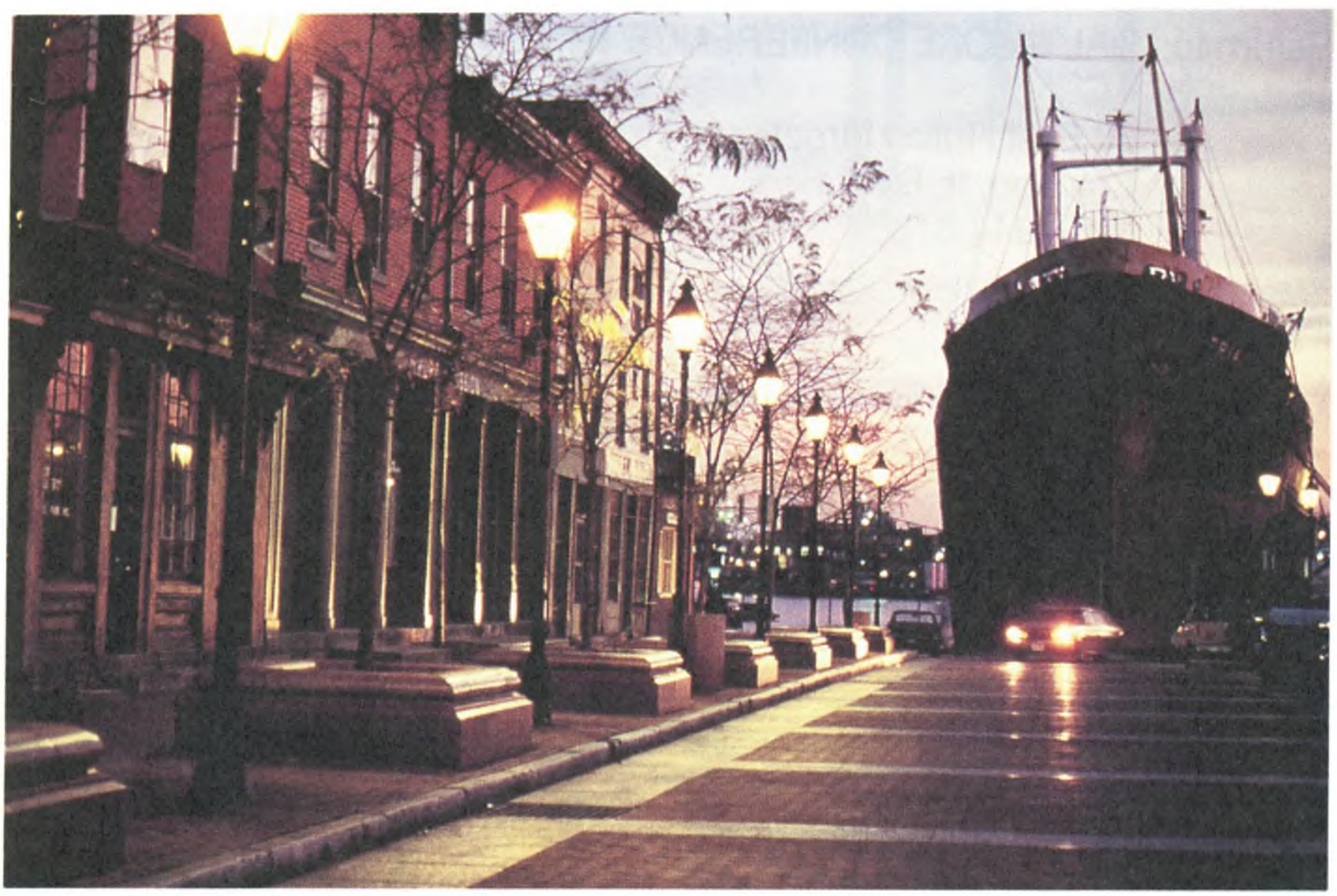

Fells Point harbor area at the foot of Broadway Street at night. 
date up to a total of 8 persons at $\$ 40$ for a single or $\$ 55$ for a double. No credit cards; a deposit is required. Right down the street at $112 \mathrm{E}$. Montgomery Street in the Federal Hill Historic District is Harborview Bed \& Breakfast, (301) 528-8692, which has three rooms priced at $\$ 65$ per room. Depending upon the number of guests, breakfast is served either in the kitchen or the dining room. No credit cards.

Rachael's Dowry is a townhouse in Ridgely's Delight, a few blocks west of the Convention Center at 621 Washington Boulevard, (301) 385-2656. There are only two guest rooms, which rent for $\$ 50$ as singles or $\$ 55$ as doubles. Credit card numbers can be used to reserve a room, but the owner prefers cash or travelers checks for payment. Breakfast is in the dining room. The Traveller in Maryland is a bed and breakfast booking agency which caters to individuals. Tourists are matched with compatible hosts in private homes of quality. Room prices range from $\$ 45$ to $\$ 65$ per night for double occupancy. Continental breakfast is furnished. The office is at 33 West Street, Annapolis, MD 21401, but the staff prefer to make reservations from $9 \mathrm{a} . \mathrm{m}$. to 5 p.m. by phone, (301) 269-6232, or local line 2612233 from Washington, if you are there on business.

For the youthful librarian on a tight budget, Baltimore now boasts an American Youth Hostel, just across the street from Enoch Pratt's Central Library, where there will be a reception on Wednesday evening. The hostel address is $17 \mathrm{~W}$. Mulberry Street, (301) 576-8880. $\$ 7$ per night for members; $\$ 10$ for non-members; dorm-style with some light cooperative work required.

\section{Proceedings}

The Conference Proceedings will be available in Baltimore and all full conference registrants will receive a complimentary copy. Daily conference registrants may purchase copies on-site for $\$ 10$. Copies will be sold after Conference at a cost of $\$ 22$ to members and $\$ 30$ to non-members.

ACRL members should have received registration materials in December. If not, fill out and send in the form below.

Non-members-detach this section and send ior your registration materials.

I am not a member of ACRL.

I am interested in the BALTIMORE CONFERENCE.

Please send me the preliminary program and registration materials.

Return to: BALTIMORE CONFERENCE
ACRL/ALA
50 East Huron Street
Chicago, IL 60611
(312) $944-6780$

Type or print

Name

last first

Address

street

city state zip code

Phone

Please send me membership information 


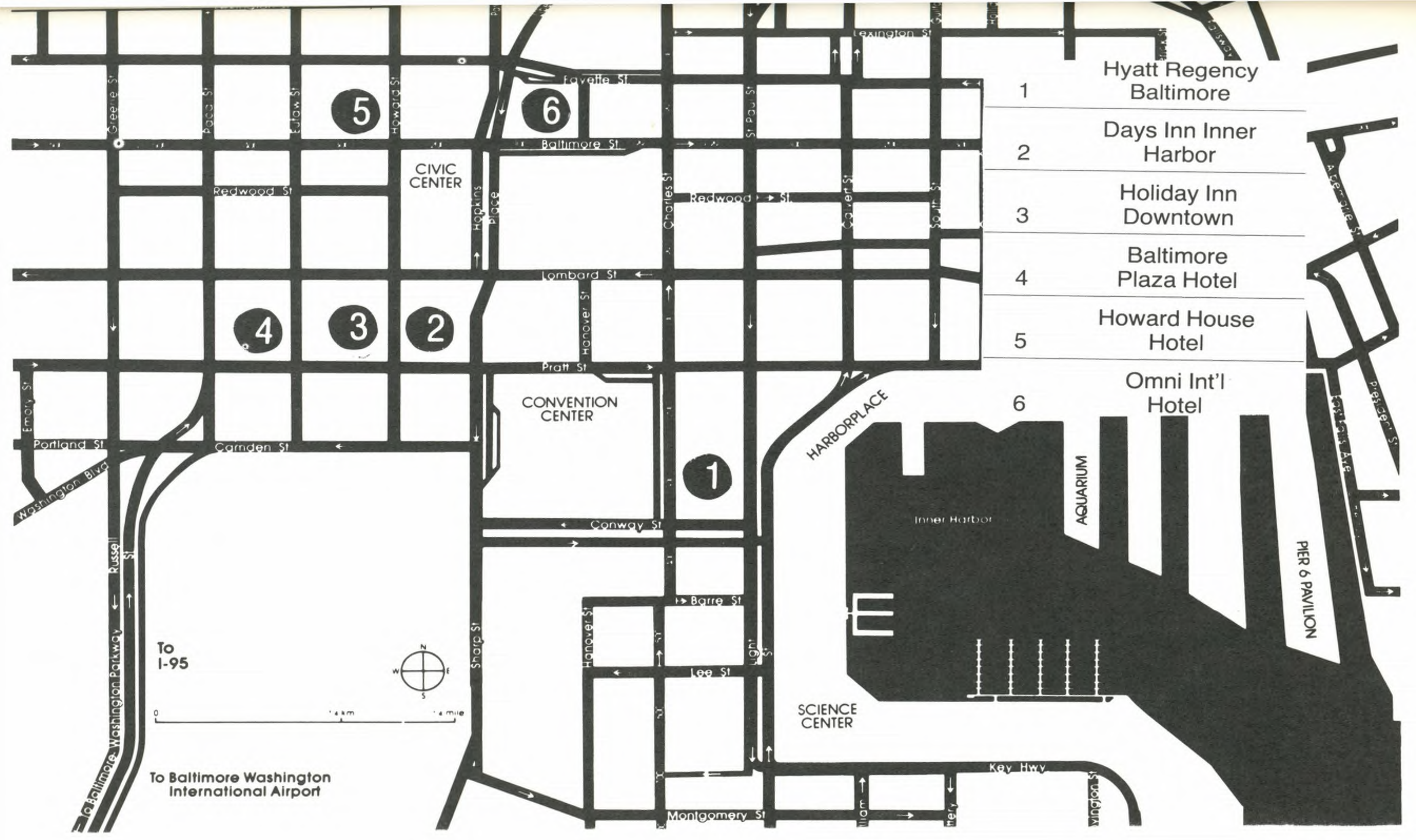




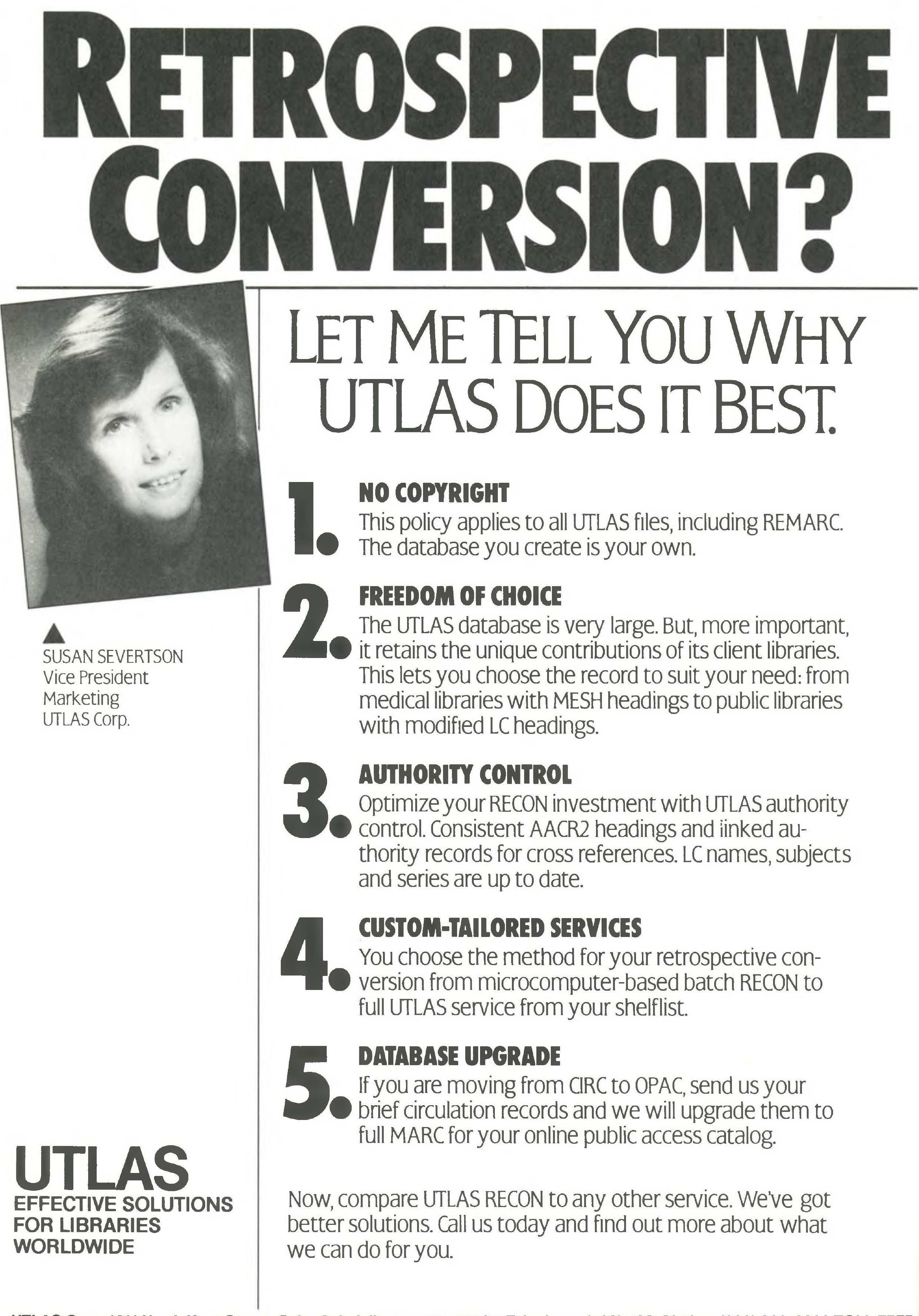

UTLAS Corp. 1611 North Kent Street, Suite 910, Arlington, VA. 22209 Telephone (703) 525-5940 or (800) 368-3008 TOLL FREE 


\section{Exhibits Program}

Attendees can visit 180 exhibits of publishers, audio-visual producers, equipment and materials suppliers, networks and consortia, wholesalers and jobbers, computer and micrographics suppliers, computer-based reference services-one of the largest exhibits of its kind in the nation. Exhibitors at the conference (as of December 1985) include:

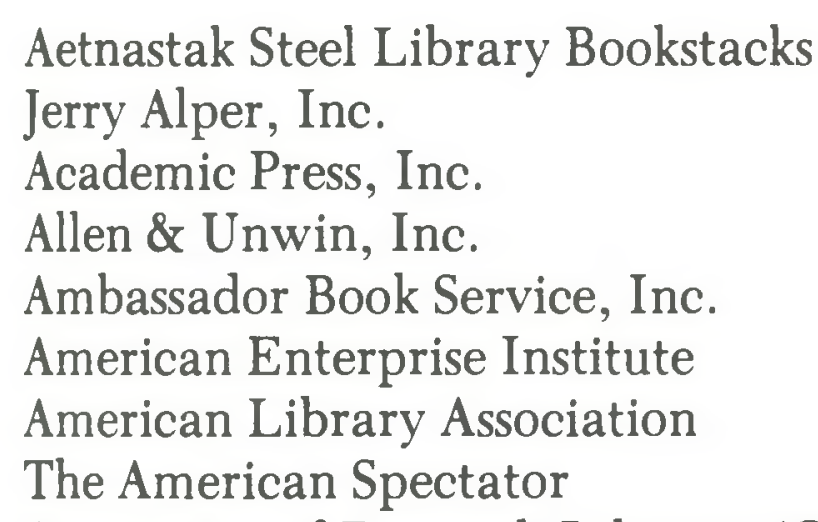

Franklin Book Co.

Gaylord Bros., Inc.

Geac Computers International

Genealogical Publishing Co., Inc.

Greenwood Press

Grove's Dictionaries of Music/Stockton Press

G.K. Hall

Hammond, Inc.

Otto Harrassowitz

The Heckman Bindery, Inc.

The Heritage Foundation

Humanities Press International, Inc.

Information Access Co.

Innovative Interfaces, Inc.

Institute for Scientific Information

Kraus International Publications

Peter Lang Publishing

Library Binding Service, Inc.

The Library Corporation

Library of Congress, Cataloging Distribution Service

Longwood Publishing Group

McGregor Subscription Service, Inc.

John Menzies Library Services, Ltd.

Midwest Library Service

National Archives

National University Continuing Education Association

NewsBank, Inc.

Nichols Publishing Co.

Martinus Nijhoff International

NOTIS

OCLC, Inc.

Opinion Research Service

Organization for Economic Cooperation and Development

The Oryx Press

Oxford University Press

Pergamon Press, Inc.

Plenum Publishing Corp.

Public Affairs Information Service, Inc.

The Publishers Book Exhibit, Inc.

Puvill Libros S.A.

Readex Corp.

Read-More Publications, Inc.

Research Publications

The Riverdale Co., Publishers

Ross Book Service: Tools of the Trade

K.G. Saur, Inc.

Schoenhof's Foreign Books, Inc.

Scholarly Resources, Inc.

Shoe String Press/Library Professional Publications

Silver Platter Service

Sociological Abstracts, Inc.

Spacesaver Corp.

Springer-Verlag New York, Publishers

Swets Subscription Service 
UNIPUB

University Microfilms International

University Press of America

University Publications of America

UTLAS Corp.

VCH Publishers, Inc.

Van Nostrand Reinhold/Jane’s Publishing
Wei T'o Associates, Inc.

John Wiley \& Sons, Inc.

H.W. Wilson, Inc.

Yankee Book Peddler, Inc.

Roy Young Bookseller, Inc.

Xerox Corporation

\section{Special Events}

\section{Enoch Pratt Free Library: Opening Reception}

Enoch Pratt Free Library is one of the premier public research libraries in the country. Its current stately central branch was built in 1933 with a street-level entrance for easy access and twelve large display windows to lure visitors through the iron grille-work doors into the rich wood-panelled interior, carefully matched in the 1985 building renovation.

All registrants of the ACRL Conference are invited to enjoy wine and cheese, fruit, and cookies with coffee or tea in the beautiful and intellectually-stimulating building-affectionately known as The Pratt-on Wednesday evening, April 9, 9:30-11:30 p.m. This all-conference reception is free of charge. There will be three musical ensembles including the John Wessner Jazz Quartet; the Ken Kolodner and Christopher Norman group playing traditional music on the hammer dulcimer, fiddle and flute; as well as a classical trio.

\section{National Aquarium Reception}

Over one million gallons of water and over 8,000 beautiful, strange, and/or fearsome creatures greet visitors to the National Aquarium in Baltimore, one of the largest and most sophisticated aquaria in the country. Travel from a Maine cove to a tropical rain forest to an Atlantic coral reef and finally to the ocean depths. On your journey, enjoy a delicious antipasto buffet-including vegetables and dips, fruit, pasta salad, a variety of Italian meats, cheeses, and breads - and elegant desserts. A cash bar will also be available, and complimentary tea and coffee. This gala party on Thursday evening, April 10, from 7:00-11:00 will give you an opportunity to visit one of Baltimore's major tourist attractions in uncrowded splendor. Mingle with friends and fish for an evening!

\section{National Agriculture Library Tour}

The National Agricultural Library (NAL) and Beltsville Agricultural Research Center (BARC), Beltsville, Maryland, will host a tour of their facilities on Tuesday, April 8, from 8:00 a.m. to 3:30 p.m. at no charge.

Enjoy an opportunity to visit NAL, the largest agricultural library in the free world. A guided tour will show you "first hand" NAL's facilities, including several exciting new technologies under development. Meet NAL staff and learn more about the actual functioning of this national library.

In the afternoon a tour of BARC will guide you through one of the largest and most diversified research complexes in the world. BARC's international reputation brings thousands of visitors each year from the United States and abroad to tour the Center-home to several world-renowned research collections.

Participants will board a bus at 8:00 a.m. at the Pratt Street entrance to the Baltimore Convention Center. The Bus will depart for its return to Baltimore at 3:30 p.m.

If you wish to attend this tour, send your name, address and telephone number by March 24, 1986, to: Maria G. Pisa, Leader, Special Services and Communications, National Agricultural Library, U.S. Department of Agriculture. Beltsville, MD 20705.

\section{SPEcial Tours}

Several tours have been arranged to suit both your recreational and professional interests. They are being provided by Baltimore Rent-a-Tour, 3414 Philips Drive, Baltimore, MD 21208. You may use the form provided in your registration packet to reserve space for any of these tours. The mail reservation deadline is March 24; after that time reservations will be made on a space available basis at the Hospitality Booth in the Convention Center.

A) Library of Congress, Tuesday, April 8, 1986, 12:00 noon-5:00 p.m. Cost: \$16/person.

Take a Busman's Holiday to the mecca of the library world - the Library of Congress. En route to the Capital enjoy a gourmet box lunch and ready yourself for a behind the scenes tour of the Library of Congress.

B) Baltimore: Its History, Culture and Charm, Wednesday, April 9, 1986, 9:00 a.m.-12:00 noon. Cost: $\$ 10 /$ person.

Your tour will include visits to the famed Johns Hopkins Medical School, The Walters Art Gallery, The Lexington Market and other famous sites. 


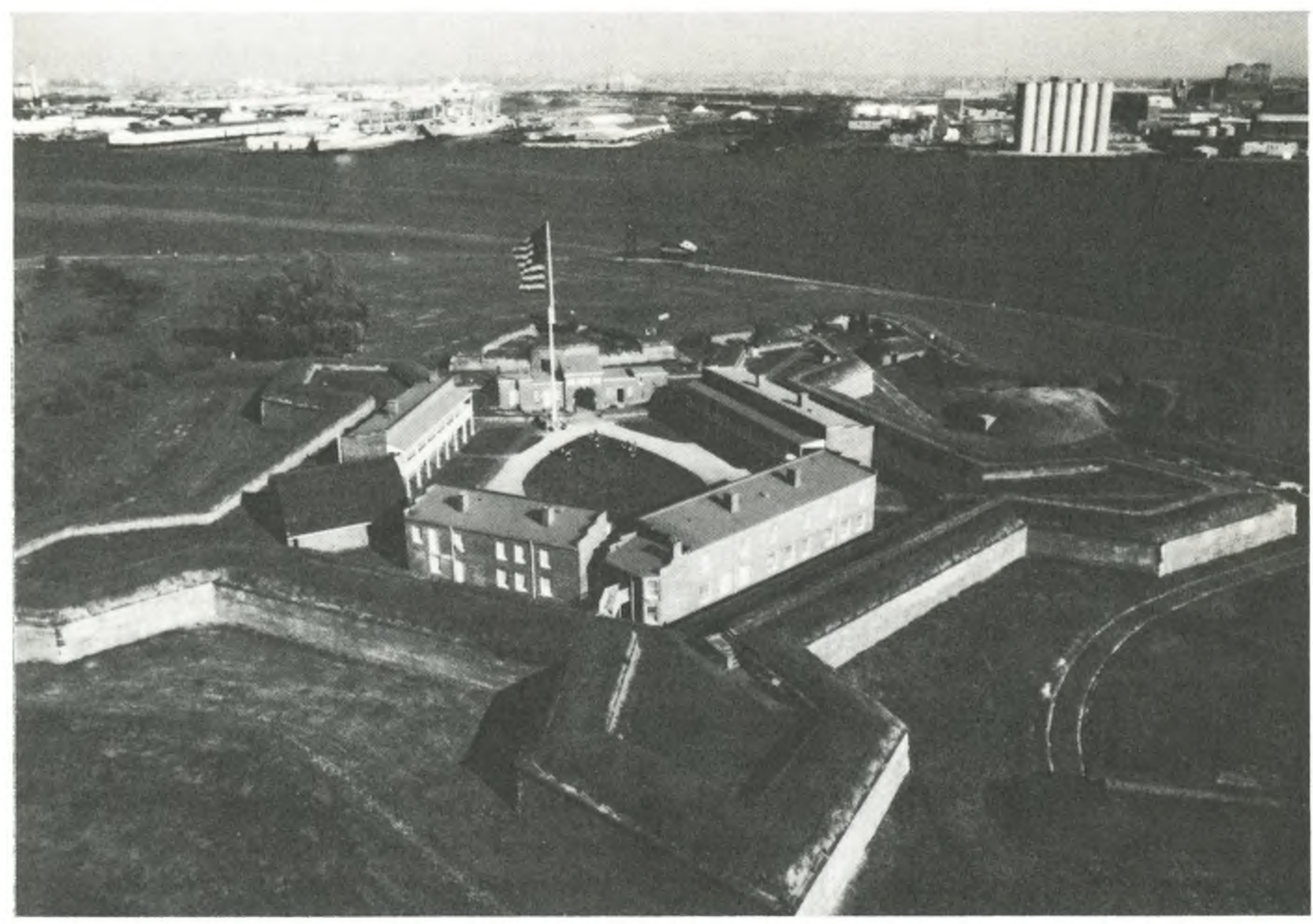

The bombardment of Fort McHenry in 1814 inspired Francis Scott Key's "Star-Spangled Banner."

Your well-informed guide will tell historical facts and anecdotes about places and personalities. A highlight of the tour will be a visit to Fort McHenry (birthplace of the Star Spangled Banner).

C) Maryland Historical Society and George Peabody Library, Wednesday, April 9, 1986, 9:00 a.m.-12:30 p.m. Cost: \$8/person.

Founded in 1844, the Maryland Historical Society is a repository of books, silver, furniture, and portraits related to Maryland's history. The Peabody Library, boasting one of Baltimore's most beautiful interior spaces, was built in 1866 and originally belonged to benefactor George Peabody. Lunch on your own in the beautiful Mt. Vernon Square area (restaurant list provided at time of tour).

D) Fells Point Pub Crawl, Thursday, April 10, 1986, 9:00 p.m.-12:00 midnight. Cost: \$8/person.

A coach will transport you to and from Fells Point, a National Historic district with portside houses dating to the 1700s. A list of pubs will be provided to tour participants who may care to linger in one pub or move from one to another.

E) Baltimore's Famous Early Bird Insomniac Tour, Friday, April 11, 1986, 8:00 p.m.-1:00 a.m. Cost: $\$ 23 /$ person.

See cultural and historic Baltimore after dark. The tour begins with a view of Baltimore's city lights from atop historic Federal Hill. Tour stops include the Baltimore Museum of Industry, the printing area of the Baltimore Sun, dessert and coffee at Baltimore's famous Haussner's restaurant, a glass of sherry at Edgar Allan Poe's grave, and a streetcar ride at the Baltimore Streetcar Museum.

F) Ethel's Place, Friday, April 11, 1986, 8:00 p.m.-12:00 midnight. Cost: $\$ 8 /$ person.

Spend a chic Friday evening at Ethel's Place (proprietor: Ethel Ennis) and enjoy Baltimore's best in jazz. Transportation to this night club in Baltimore's cultural Mt. Vernon area will be provided. Cover charge and cost of drinks will be the responsibility of participants.

G) Prince George's Community College, Saturday, April 12, 1986, 1:00-5:00 p.m. Cost: \$16/person.

Prince George's Community College has recently celebrated the opening of its new Library Media Center. Take a leisurely bus ride, enjoy a gourmet box lunch, and then tour this impressive new facility.

\section{Free Local Library Tours}

Several tours of local libraries are planned to encourage conference attendees to visit local academic libraries (for a description of these libraries, please see C\&RL News, June 1985, p.299). Transportation, if required, will be provided by volunteers.

The tours listed below are scheduled for Friday, April 11, 1986, 9:00-11:00 a.m.:

Eisenhower Library, Johns Hopkins University (this is the Homewood campus, not the Medical School)

Soper Library, Morgan State University

Loyola-Notre Dame Library

Harbor Campus Library, Community College 
of Baltimore

Julia Rogers Library, Goucher College, and Cook Library, Towson State University

Kuhn Library and Gallery, University of Maryland, Baltimore County

The tour listed below is scheduled for Thursday, April 10, 1986, 4:00-6:00 p.m., and includes demonstrations of the Integrated Library system and GEAC system as well as a reception. Both libraries are within walking distance from the Convention Center:

University of Maryland Health Services Library and University of Maryland Law Library

To sign up for the Free Local Library Tours, use the form in your conference registration packet.

Several guides to Baltimore activities and points of interest, including restaurants, bookstores, and places to listen to music have been assembled for conference attendees and will be available at the Hospitality Desk in the Convention Center. A special guide prepared by the Easter Seals Society, entitled Bright Lights, Harbor Breezes: An Access Guide to the Revitalized Baltimore, will also be available at the Hospitality Desk.

\section{Baltimore}

Baltimore, the site of ACRL's Fourth National Conference, is an historic seaport city that grew up around one of the largest natural harbors in the world. In the 19th century tides of immigrants from all parts of Europe helped transform Baltimore into a major industrial center that continues to boast more than 2,000 factories. One of the largest residues of that effort still active is the Bethlehem Steel plant in Sparrows Point. McCormick \& Company, the world's largest producer of spices and seasonings, is directly across the street from the Light Street pavilion of Harborplace, the complex of shops and restaurants which has become the focus of Baltimore's latest transformation into a tourist mecca. The Baltimore Convention Center, where the Conference will be held, and a dozen new or refurbished hotels are within a few blocks of the Inner Harbor, which also hosts the National Aquarium, the World Trade Center, the Maryland Science Center, Six Flags Power Plant, and the "U.S.S. Constellation," the oldest fighting ship in the Navy.

Within a mile of the Convention Center are numerous historic buildings: the Basilica, which was the nation's first major Catholic cathedral; Old Otterbein United Methodist Church, built in 1785 and the oldest church in the city; the Shot Tower; the homes of both Babe Ruth and Edgar Allan Poe; and such cultural attractions as the Central Library of the Enoch Pratt Free Library, the Peabody Library, the Walters Art Gallery, the Maryland Historical Society, and the Peale Museum. There are scores of fine restaurants and shops to tempt the Conference goer. Surrounding all these buildings and mixed amongst them are more than a dozen historic neighborhoods, most of which are on the National Register. It is this happy mixture of preserved historic buildings, self-contained neighborhoods, and ethnic traditions that distinguish Baltimore as an attractive city to visit or in which to live.

For those who have a few days to travel either before or after the main attraction in Baltimore, there are numerous side trips available to places only a few miles away, such as Fort McHenry or the mill town of Ellicott City, or to delightful small cities or towns on both the Eastern and the Western Shores of the Chesapeake Bay. A visitor must really see the Bay, such as from the bridge that crosses it just east of Annapolis, to begin to feel why Maryland is so geographically distinctive. The Bay is the state's major natural resource because of its effect on shipping, as the home of several commercial seafood produucts, among which oysters are the most famous, and as the home of tens of thousands of sailboats and motor boats.

Three towns on the Eastern Shore are particularly attractive to visitors. St. Michael's is an old waterfront community that has a maritime museum, several seafood restaurants, and shops. Not far away but inland is Easton, the county seat of Talbot County, home of some of the wealthiest people in the country, such as the Stanleys who help underwrite "All Things Considered" on National Public Radio. The Third Haven Quaker Meeting House, erected in Easton between 1682 and 1684 , is one of the oldest historic attractions in the state. Farther north is Chestertown, an old riverfront county seat, which has several notable houses facing the river, a quaint courthouse square, and Washington College, founded in 1782 - a fine liberal art college.

On the Western Shore in Annapolis, capital of the State and briefly capital of the country in 1783-84. It boasts the U.S. Naval Academy; St. John's College, whose library houses Thomas Bray's colonial library; the Hall of Records, currently home of the Maryland State Archives; and dozens of historic houses, the most notable being the Hammond-Harwood House and the Pace House and Gardens. In downtown Annapolis, clustered around the harbor, are many fine restaurants and specialty stores. During the week of the Conference, the London Town Publick House and Gardens on the South River just below Annapolis will host its annual Daffodil Show. And an hour west of Baltimore is Frederick, the trading center for a rich farm and dairy countryside. There is a 


\section{ACQUISITION PERSPECTIVES}

1. ANY BOOK IN PRINT

means delivery to your library of all available books from any publisher or distributor in the U.S. or Canada. There is no list of publishers you must check ... WE DELIVER THEM ALL ... including trade, scientific/technical, text, university presses, paperbacks, associations, small presses, Canadian, and software.

Send us your direct orders and experience the "added value" received when using Book House.

\section{ANT BOOK it PRitit}

IN THE UNWED STATES AND CENADE

BOOK HOUSE

\section{COMPTAL DHANAR?}

3 OPAN ORDAR RAPORTS

4 ECCURTES BOOR DHATHE?

CALL TOLL-FREE TODAY

1-800-248-1146

In Canada \& Michigan

CALL COLLECT (517) 849-2117

OCLC Vendor No. 17397

SAN 169-3859

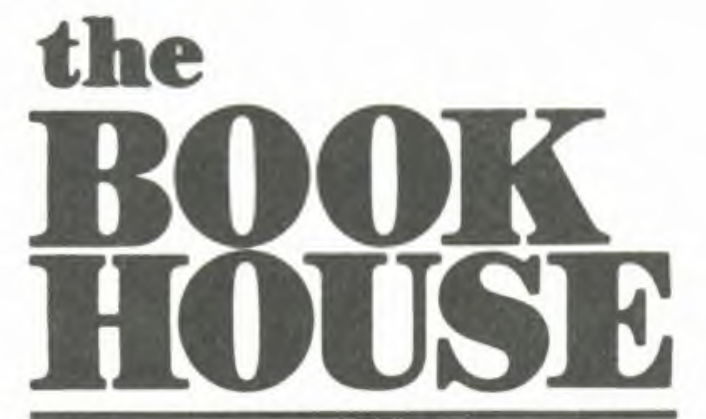

JOBBERS SERVING LIBRARIES WITH ANY BOOK IN PRINT SINCE 1962 208 WEST CHICAGO STREET JONESVILLE, MICHIGAN 49250 
strong German heritage in Frederick. The Barbara Fritchie House and Museum of flag fame is probably the best known site in town. Several lovely churches with tall spires mark the skyline, which has not yet been ruined by highrises, although the suburbs of both Baltimore and Washington approach Frederick. The courthouse square, Hood College, and several antique stores also beckon to visitors. New Market, a few miles east of Frederick, has about two dozen antique shops.
And for visitors from out west who have never done the big tourist attractions back east, within a drive of from one to three hours are all the things to see in Washington; Harper's Ferry, Gettysburg, Antietam, and numerous other Civil War battlefields; Richmond; Williamsburg; and Philadelphia. In fact, one of the nicest features of Baltimore is its proximity to so many other interesting places, connected by superb highways and, in many cases, public transportation.-Bill Wilson.

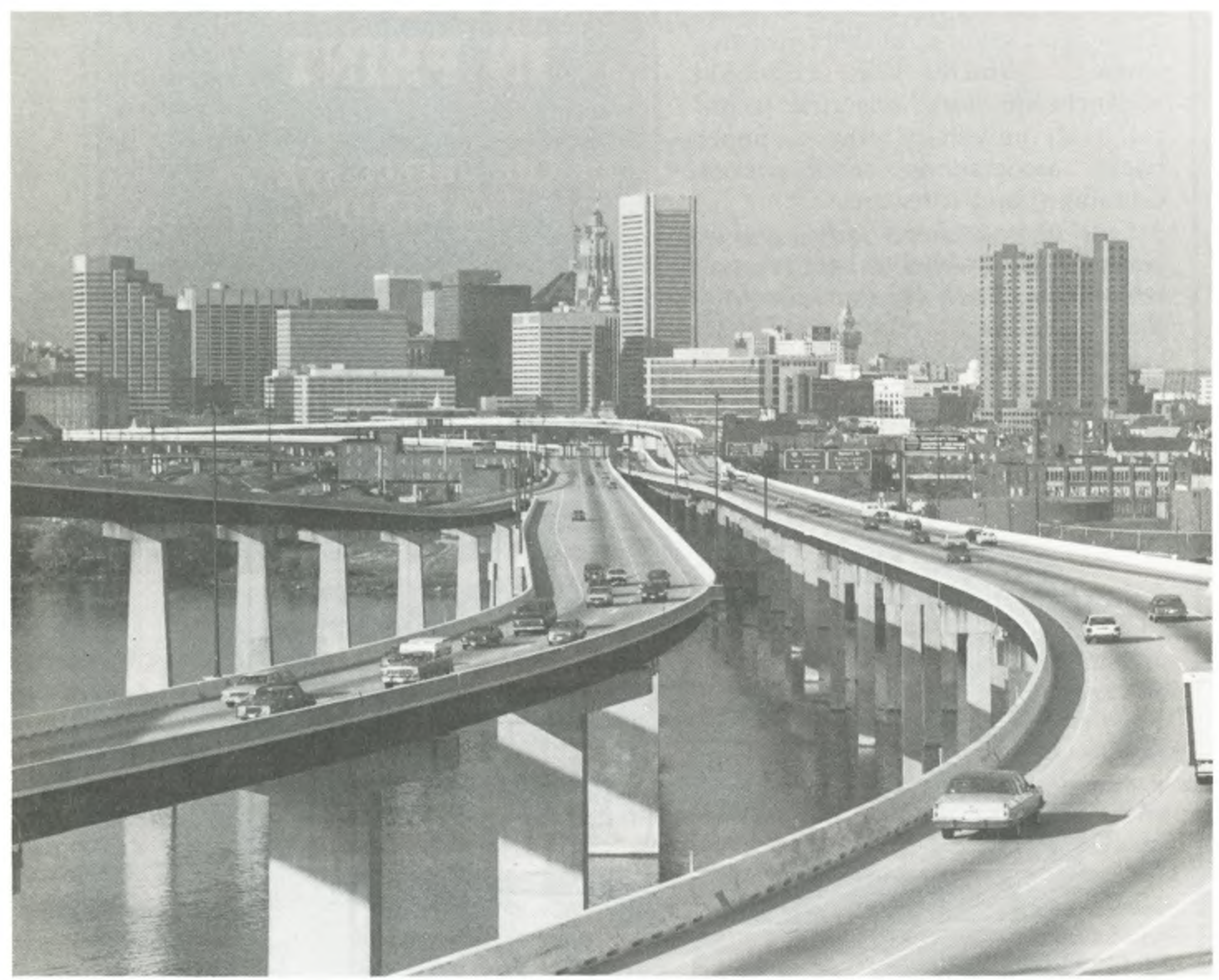

The Baltimore skyline viewed from the south via Interstate 395.

\section{Photo Credits}

Baltimore Convention Bureau: front cover, pp. 19,20 (mayor), 22, 32, 33, 44, 49, 56, 57, 63, 66, 68.

Enoch Pratt Free Library: p. 25.

Johns Hopkins University: pp. 42, 43

Library of Annapolis and Anne Arundel County: p. 30

Richard Lippenholz: pp. 32, 49, 57, 63, 66

Alan M. Scherr: p. 37.

Towson State University: p. 47 
One incomparable information provider puts the world of public policy literature at your fingertips!
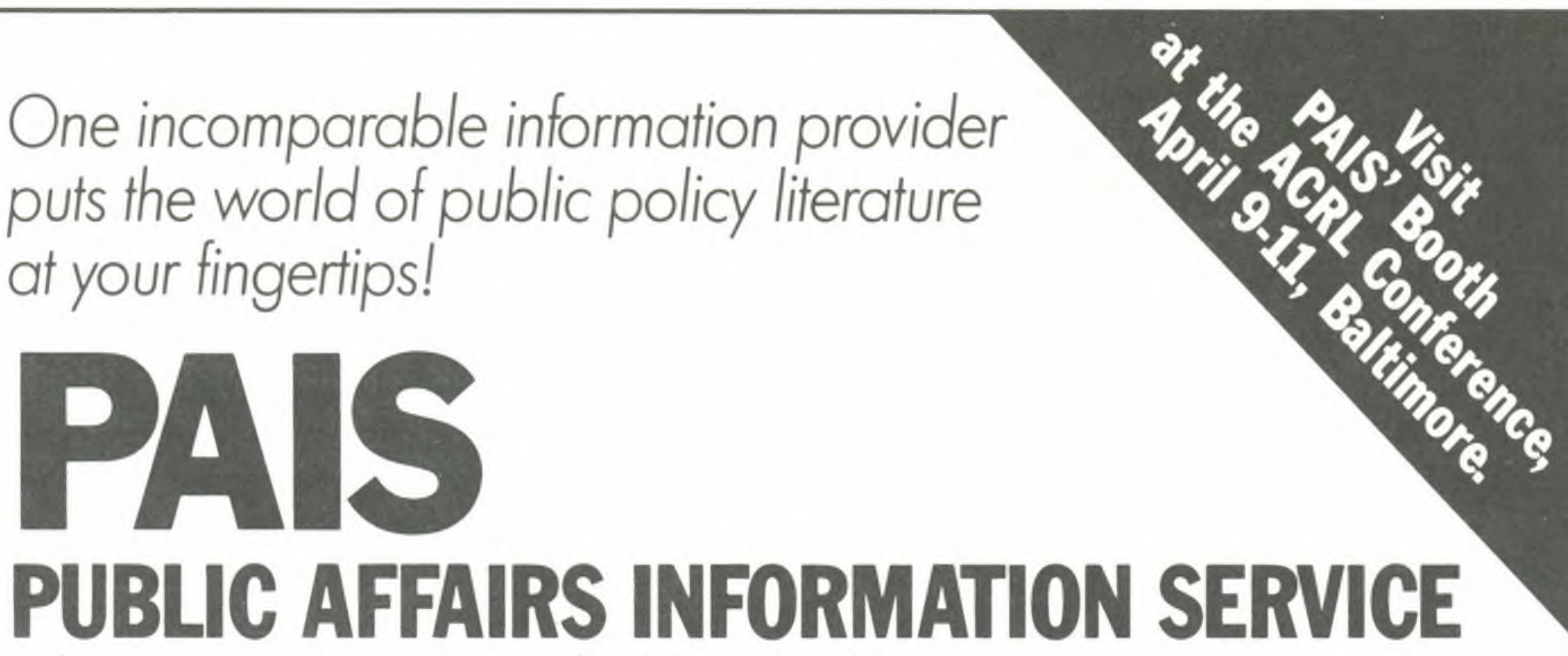

\section{PUBLIC AFFAIRS INFORMATION SERVICE}

When it comes to coverage of public policy literature as it pertains to.

- business and economics a public administration banking and insurance

- legal trends statistics, demographics and all the social sciences. . no indexing resource can match PAIS. Get fast, easy access to an unparalleled wealth of current literature from the world over using these PAIS products:

\section{PAIS BULLETIN-The "Standard" Public Policy Reference Resource.}

When searching for up-to-date literature published in English, look no further than PAIS BULLETIN. From economics, law and political science, to banking, public administration, finance, labor and much more, the BULLETIN covers a wide range of multidisciplinary literature.

\section{PAIS FOREIGN LANGUAGE INDEX-For International Coverage, And Worldwide Perspective.}

Enhance your reference capabilities with strong international coverage provided by the PAIS FOREIGN LANGUAGE INDEX. It gives you access to a stringently edited range of public policy literature published in French, German, Italian, Spanish and Portuguese. It enables you to locate items quickly and easily via English-language subject headings and abstract-like notes.

\section{Special Features Make PAIS Your Incomparable Information Source.}

- Multidisciplinary Coverage. Only PAIS covers so many vital contemporary topics and issues, from so many pertinent angles.

- Multiformat Coverage. PAIS covers all relevant business/professional journals and monographs-plus reports, government documents and many other valuable information sources.

- Selectivity \& Accuracy. PAIS' thorough editorial process also assures coverage of the best information from superior sources. Painstaking editing also results in unsurpassed accuracy of citations.

- New Abstract-Like Notes. Now all PAIS publications have informationrich abstract-like notes for more than $95 \%$ of indexed items.

\section{PAIS INTERNATIONAL, the PAIS online database, is available on DIALOG and BRS.}

Call 800-841-1416 today for complete details and ordering information. (In NY, call 212-869-6186.)

Public Affairs Information Service • 11 W. 40th Street • New York, NY 10018-2693 


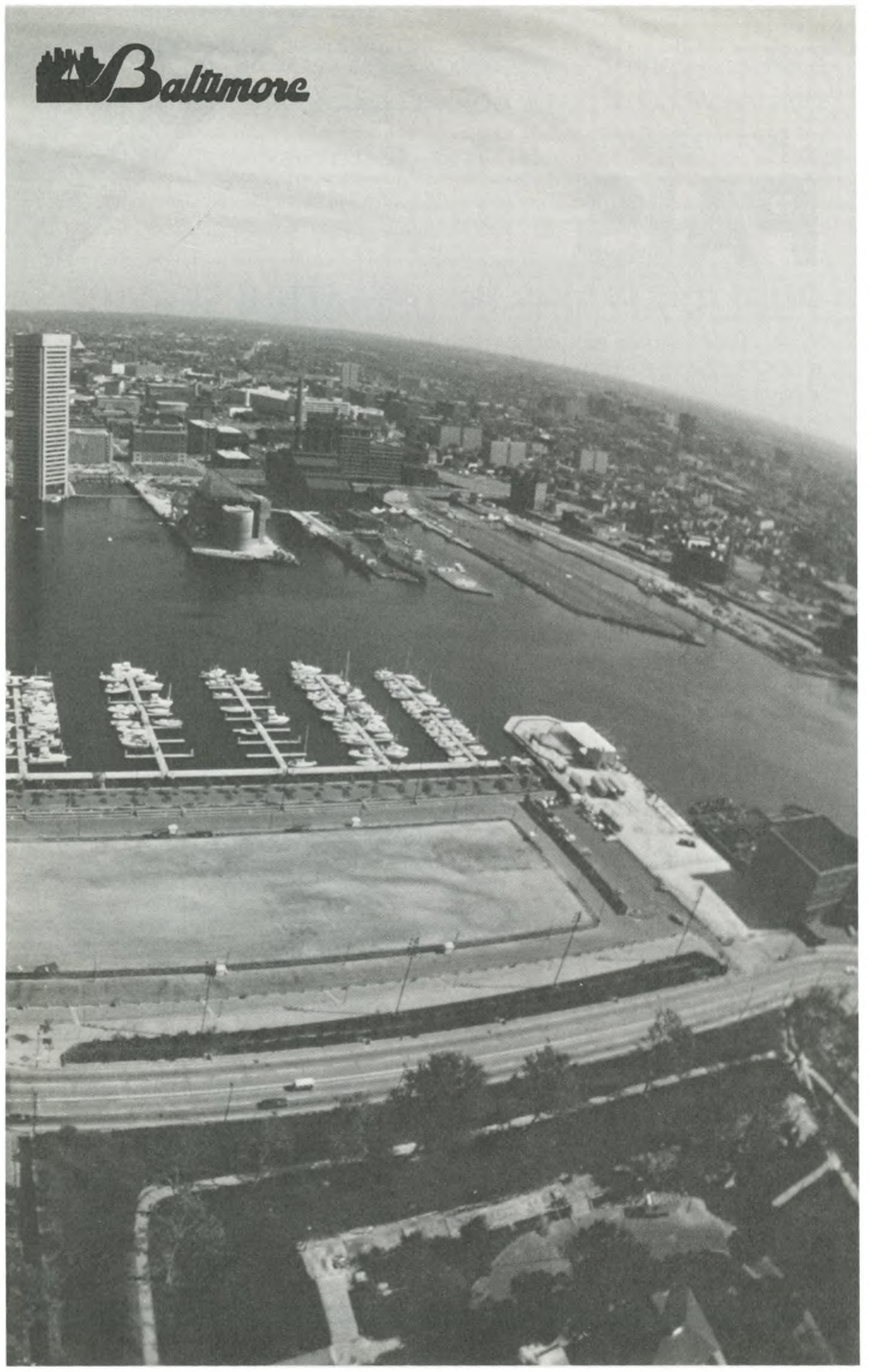

